NBER WORKING PAPER SERIES

DISCRIMINATION, MANAGERS, AND FIRM PERFORMANCE:

EVIDENCE FROM “ARYANIZATIONS” IN NAZI GERMANY

\author{
Kilian Huber \\ Volker Lindenthal \\ Fabian Waldinger \\ Working Paper 28766 \\ http://www.nber.org/papers/w28766 \\ NATIONAL BUREAU OF ECONOMIC RESEARCH \\ 1050 Massachusetts Avenue \\ Cambridge, MA 02138 \\ May 2021
}

We are particularly grateful to John List, Erik Hurst, Dirk Jenter, and Daniel Sturm, as well as Nicholas Bloom, Maristella Botticini, Kerwin Charles, Neale Mahoney, Alan Manning, Stephan Maurer, Filippo Mezzanotti, Stefan Nagel, Yona Rubinstein, Raffaella Sadun, Heather Sarsons, Claudia Steinwender, John Van Reenen, and many seminar audiences for helpful comments. We thank our research assistants Matthias Bing, Le Van Cao, Thomas Decker, Katharina Drechsler, Miguel Fajardo-Steinhauser, Felicitas Filsinger, Lukas Franz, David Full, Sebastian Hager, Hannes Halder, Robert Johannes, Kenan Jusufovic, Katharina Knuth, Tobias Nowacki, Franz Oertel, Constanze Vorrath, Saskia Wendt, and Stefan Wies for their outstanding work. We thank Dieter Ziegler, Martin Muenzel, and Paul Windolf for generously sharing data on senior managers in Germany. Waldinger gratefully acknowledges start-up funding from the Innovation Policy working group at the NBER and funding from ERC Starting Grant No. 335573. The views expressed herein are those of the authors and do not necessarily reflect the views of the National Bureau of Economic Research.

NBER working papers are circulated for discussion and comment purposes. They have not been peer-reviewed or been subject to the review by the NBER Board of Directors that accompanies official NBER publications.

(C) 2021 by Kilian Huber, Volker Lindenthal, and Fabian Waldinger. All rights reserved. Short sections of text, not to exceed two paragraphs, may be quoted without explicit permission provided that full credit, including $\odot$ notice, is given to the source. 
Discrimination, Managers, and Firm Performance: Evidence from "Aryanizations" in Nazi

Germany

Kilian Huber, Volker Lindenthal, and Fabian Waldinger

NBER Working Paper No. 28766

May 2021

JEL No. D22,E60,G30,J7,J71,M12,N24,N34,N8

\begin{abstract}
$\underline{\text { ABSTRACT }}$
Large-scale increases in discrimination can lead to dismissals of highly qualified managers. We investigate how expulsions of senior Jewish managers, due to rising discrimination in Nazi Germany, affected large corporations. Firms that lost Jewish managers experienced persistent reductions in stock prices, dividends, and returns on assets. Aggregate market value fell by roughly 1.8 percent of German GNP because of the expulsions. Managers who served as key connectors to other firms and managers who were highly educated were particularly important for firm performance. The findings imply that individual managers drive firm performance. Discrimination against qualified business leaders causes first-order economic losses.
\end{abstract}

Kilian Huber

Booth School of Business

University of Chicago

5807 S. Woodlawn Avenue

Chicago, IL 60637

and NBER

kilianhuber@uchicago.edu

Volker Lindenthal

University of Munich

Department of Economics

Schackstr. 4

80539 Munich

Germany

volker.lindenthal@econ.lmu.de
Fabian Waldinger

University of Munich

Department of Economics

Schackstr. 4

80539 Munich

Germany

fabian.waldinger@econ.lmu.de 
Large-scale increases in discrimination can lead to dismissals of highly qualified business leaders and managers. Discriminatory expulsions of individuals holding important positions in the economy have occurred over and over again, both historically and in modern times. ${ }^{1}$ Recent political developments have renewed interest in the economic effects of this type of discrimination. For instance, the U.S. travel ban on citizens of seven Muslim-majority countries has raised fears among large corporations that increasing discrimination will leave them unable to retain talent. ${ }^{2}$

Discriminatory dismissals are, of course, extremely hurtful to targeted individuals. But there is little evidence on whether such discrimination can cause large and persistent economic losses for firms and the economy as a whole, beyond hurting the welfare of the discriminated individuals.

In this paper, we analyze arguably the most horrendous episode of discrimination in human history, the treatment of Jews in Nazi Germany. We examine how the removal of senior managers of Jewish origin, caused by the rise of antisemitism in Nazi Germany, affected large German firms. After the Nazis gained power on January 30, 1933, discrimination against Jews quickly became commonplace in Germany. By 1938, individuals with Jewish ancestry had effectively been excluded from the economy.

Using newly collected data, we show that firms that had employed managers of Jewish origin were unable to replace them adequately. Stock prices, dividends, and returns on assets of these firms declined, relative to unaffected firms after 1933, and did not recover for at least ten years, the end of our sample period. Stock prices only fell for firms that lost highly qualified managers with specific characteristics (university education and connections to other firms). A back-ofthe-envelope calculation suggests that expelling managers of Jewish origin reduced the aggregate market valuation of firms listed in Berlin by 1.8 percent of German gross national product. ${ }^{3}$ This sizable decrease shows that individual managers have large effects on firm performance and that a discriminatory ideology can lead to first-order economic losses.

Before the rise of the Nazis, managers of Jewish origin played a key role in the German economy. In fact, the "economic role of Jews in Germany [...] was greater than that in Western industrialized countries like England, France, or Holland. It also exceeded almost certainly their role

\footnotetext{
${ }^{1}$ In Turkey, several thousand managers who follow the cleric Fethullah Gülen have been arrested or have fled overseas since 2016, fueling concerns of an economic collapse (The Economist 2017b). In Uganda, Asians made up less than one percent of the population but owned 90 percent of businesses and paid 90 percent of tax revenue. In 1972, all Asians were expelled by Idi Amin (BBC 2016). Due to "race prejudice" during World War II, the United States interned Japanese-Americans (U.S. CWRIC 1982). Many were highly educated and important managers in the food industry (Chin 2005). In Indonesia, ethnic Chinese have an "impressive business presence," but have faced repeated waves of discrimination; for instance, forced emigration in 1959 and riots in 1998 (Koning 2007). In France, the Huguenots were among the "wealthiest merchants and most successful industrialists" (Scoville 1953). Following religious persecution, over 200,000 Huguenots left France for England, the Dutch Republic, and Prussia in 1685 (Hornung 2014).

${ }^{2}$ Concerned firms include Amazon (Wingfield and Wakabayashi 2017), Nike (Cox 2017), MasterCard (McGregor 2017), and Ben \& Jerry's (Solheim 2017).

${ }^{3}$ This number is likely to be a lower bound for the aggregate economic losses to the German economy, since Jews were also removed from lower-level positions, firms not listed in Berlin, and important positions in universities, law courts, hospitals, and cultural institutions. Of course, this number also does not do justice to the indescribable human suffering and loss of life that the Nazi ideology brought on Jews and other targeted groups.
} 
in the development of the American economy" (Mosse 1987, p. 23). Managers of Jewish origin were assimilated into the German economic elite. They worked in all types of firms, including some of the largest German firms that were not associated with Judaism in any way (for example, Allianz, BMW, Daimler-Benz, Siemens \& Halske, and I.G. Farben). After the Nazis gained power, antisemitism surged across the whole economy and German firms began to dismiss managers of Jewish origin. Deutsche Bank, for example, forced CEO Oscar Wassermann and executive Theodor Frank to resign their positions by June 1, 1933 (James 2001, pp. 25-26). The dismissals targeted a range of individuals, including Christians who had just one Jewish grandparent. Firms that happened to employ managers of Jewish origin lost a significant fraction of their senior managers as a result of antisemitic discrimination. Other firms did not have any managers of Jewish origin and, therefore, remained unscathed.

To carry out our analysis, we collect the names and characteristics of individuals holding around 30,000 senior management positions in 655 German firms listed on the Berlin Stock Exchange. We also digitize more than 240,000 daily stock prices from a historic publication series by the Berlin Stock Exchange, as well as data on dividends and returns on assets from historic volumes of Handbuch der deutschen Aktiengesellschaften. We consult various historical sources to identify which managers were of Jewish origin. While the fraction of Jews among the German population in the early 1930 s was only 0.8 percent, our new data show that 15.8 percent of senior management positions in listed firms were held by individuals of Jewish origin in 1932 (which for simplicity we call "Jewish managers"). Jewish managers had exceptional characteristics compared to other managers in 1932. For example, Jewish managers were more experienced, educated, and connected (by holding positions in multiple firms). After the Nazis gained power, the share of Jewish managers plunged sharply in 1933 (by about a third), and dropped to practically zero by 1938.

We present four main sets of results. First, we show that the expulsion of Jewish managers changed the characteristics of managers at firms that had employed a higher fraction of Jewish managers in 1932. The number of managers with firm-specific tenure, general managerial experience, university education, and connections to other firms fell significantly, relative to firms that had employed fewer Jewish managers in 1932. The effects persisted until at least 1938, the end of our sample period on manager characteristics.

Second, we show that the loss of Jewish managers reduced firms' stock prices. After the Nazis came to power, the stock price of the average firm that had employed Jewish managers in 1932 (where 22 percent of managers had been of Jewish origin) declined by 10.3 log points, relative to a firm without Jewish managers in 1932. These declines persisted until the end of the stock price sample period in 1943, ten years after the Nazis had gained power. The results are robust to controlling for firms' connections to the Nazi Party (Ferguson and Voth 2008), size, age, and industry, and to analyzing only firms that had employed at least one Jewish manager in 1932. 
We proceed to investigate whether stock prices fell because firms lost managers with specific characteristics. The results indicate that stock prices only declined for firms that fulfilled at least one of two criteria: first, firms where the Jewish managers were responsible for a large share of university-educated managers, in particular, managers with graduate education; and second, firms where the Jewish managers were responsible for a large share of connections to other firms. Stock prices did not fall for firms where the Jewish managers were responsible for only a large share of experienced managers. This is an important finding. It implies that not all firms with a higher fraction of Jewish managers in 1932 experienced lower stock prices after 1933. Hence, it is unlikely that other shocks to firms with Jewish managers in 1932 explain the declines in stock prices. Rather, the findings strengthen the view that particular managerial characteristics are important for firm performance.

We explore managerial characteristics in more detail. We find that managers with graduate education in social sciences mattered in all industries, while managers with graduate STEM education mattered only in STEM-related industries. Managers with direct connections to other firms (both to banks and non-banks) were key for firm performance, while higher order, indirect connections mattered less. Moreover, we find that share prices declined not only if a firm lost its most senior managers who were akin to a modern $\mathrm{CEO}$, but also if it lost other senior managers. This suggests that managers beyond the CEO can have large effects on firm performance. ${ }^{4}$

To examine the robustness of the results, we explore whether the declines in stock prices were caused by the removal of Jewish managers or by the general increase in antisemitism after 1933. We find that the estimated effect of losing Jewish managers remains large and significant in a sample of firms favored by the Nazi government. This suggests that repression by the Nazi government does not explain the effect of losing Jewish managers. To further explore potential government repression, we identify firms that were perceived as "Jewish" and targeted by antisemitic measures. ${ }^{5}$ We also identify firms that had large Jewish shareholders. The effect of losing Jewish managers remains unchanged when we control for effects on "Jewish firms" and firms with Jewish shareholders. ${ }^{6}$ Furthermore, stock prices of firms perceived as Jewish fell only after 1935 and recovered by 1943 , once all formerly Jewish firms had been taken over by non-Jews. The contrasting evolution of stock prices suggests that the effect of losing Jewish managers was not driven by forces that hit Jewish firms, but by forces specifically associated with the loss of Jewish managers. In additional tests, we find that the effect of losing Jewish managers is stable when we control for losses of lower-ranked Jewish employees or antisemitic retail boycotts. Moreover, the effect was

\footnotetext{
${ }^{4}$ These findings differ from the theoretical prediction in Lucas (1978), but are similar to results in Bender et al. (2018).

${ }^{5}$ We use a range of historical sources to identify "Jewish firms." These firms are distinct from firms with Jewish managers in 1932, since many German firms happened to employ managers of Jewish origin without being perceived as "Jewish," for example BMW, Deutsche Reichsbahn, or I.G. Farben.

${ }^{6}$ Recent papers by Ihlow and Jackwerth (2020) and Ritschl (2020) also discuss Jewish firms and shareholders. Their results confirm our findings (also see Section 4.3.1 on "Discrimination Against Jewish Shareholders").
} 
not driven by firms with greater exposure to various Nazi rearmament and infrastructure programs, firms with international activities, or firms hit by idiosyncratic demand shocks after 1933. Taken together, all these tests confirm that other correlated shocks cannot explain the underperformance of firms that lost Jewish managers.

In the third set of results, we estimate the aggregate cost of losing Jewish managers for firms listed in Berlin. A back-of-the-envelope calculation suggests that losing Jewish managers lowered the aggregate market valuation of firms listed in Berlin by 1.8 percent of German GNP. The calculation assumes that removing the Jewish managers had negligible spillover effects on firms that had not employed any Jewish managers in 1932. We test for such spillovers within regions and industries, and find statistically insignificant and negative spillover effects. The calculation indicates that highly qualified managers are of first-order importance to aggregate outcomes and that discriminatory dismissals can cause serious economic losses.

In the fourth set of results, we analyze the effects of losing Jewish managers on two additional measures of firm performance: dividends and returns on assets. We find that after 1933, dividends fell by approximately 7.5 percent for the average firm with Jewish managers in 1932 (which lost 22 percent of its managers). We also find that after 1933, the average firm that had employed Jewish managers in 1932 experienced a decline in its return on assets by 4.1 percentage points. These results indicate that the loss of Jewish managers not only reduced market valuations, but also led to real losses in firm efficiency and profitability.

This paper contributes to the literature by studying the effects of taste-based discrimination on firms. Becker (1957) predicted theoretically that discrimination can hurt firm profitability. We emphasize three aspects: firm-level effects of discrimination can be large, persistent, and depend on specific characteristics of the discriminated individuals. In the existing literature, a few papers use cross-sectional comparisons to analyze firm-level effects of discrimination. ${ }^{7}$ In contrast, we propose a quasi-experimental methodology to estimate firm-level effects: we identify an economywide increase in taste-based discrimination and then use firm-level variation in exposure to this shock to estimate how rising discrimination affects firms.

A further difference relative to most existing work is that we focus on the effects of discrimination "at the top," against highly qualified leaders. In contrast, the existing discrimination literature has largely analyzed how discrimination affects wages and hiring of women, Blacks, and underprivileged groups (for surveys, see Altonji and Blank 1999; Bertrand 2011; List and Rasul 2011; Bertrand and Duflo 2017).

\footnotetext{
${ }^{7}$ English soccer clubs with more Black players achieve higher league positions, conditional on the wage bill (Szymanski 2000). Firms with more female employees earn higher profits and survive for longer (Hellerstein et al. 2002; Kawaguchi 2007; Weber and Zulehner 2014). Evidence on CEO gender and firm performance is mixed (Farrell and Hersch 2005; Wolfers 2006; Adams and Ferreira 2009; Post and Byron 2015; Flabbi et al. 2019).
} 
An innovation of our approach is that we use stock prices to measure the cost of discrimination for firms. ${ }^{8}$ Stock prices are an attractive measure because they represent the present discounted value of future cash flows from holding stocks. Hence, changes in stock prices fully incorporate how market participants value the long-run costs of discrimination. Furthermore, by aggregating the firm-level estimates we can approximate the aggregate cost of discrimination for all listed firms. The existing literature contains little evidence on how changes in discriminatory attitudes affect aggregate outcomes. ${ }^{9}$

Our paper also relates to the literature on the management of large firms. Influential studies by Bloom and Van Reenen (2007), Bloom et al. (2017), and Bender et al. (2018) argue that good management practices are akin to a more efficient production technology. Several papers study the effects of encouraging firms to adopt bundles of general management practices. ${ }^{10}$ Bianchi and Giorcelli (2019) and Gosnell et al. (2020) show which specific practices raise worker productivity at large firms. These studies suggest that firms can learn and adopt better management practices.

The results of our paper highlight a complementary channel: management quality also depends on the exceptional human capital of individual managers who are hard to replace. Our findings emphasize three aspects of managerial human capital: 1) losing senior managers had large and persistent effects; 2) losing a wide cadre of senior managers, and not just the CEO, affected firm performance; and 3) losing educated and connected managers mattered, while experienced managers were less important. In contrast, several studies have focused on short-run stock returns following CEO deaths, often finding small positive or small negative effects (Johnson et al. 1985; Worrell et al. 1986; Hayes and Schaefer 1999; Borokhovich et al. 2006; Salas 2010; Nguyen and Nielsen 2010; Fee et al. 2013). ${ }^{11}$ Unlike many older managers who die, the Jewish managers in our setting were often at the peak of their ability. Consistent with our results, Jenter et al. (2017) show that only deaths of young and short-tenured CEOs cause large value losses, while Kaplan et al. (2012) and Bandiera et al. $(2017,2020)$ document that firm performance is correlated with individual managers' ability and behavior. ${ }^{12}$

\footnotetext{
${ }^{8} \mathrm{~A}$ large literature has used wages to measure discrimination. Fewer papers use other market prices. For example, a pioneering paper by List (2004) uses trading prices of sportscards to analyze whether minorities face discrimination.

${ }^{9}$ Hsieh et al. (2019) use a structural Roy model to argue that declining discrimination against women and Blacks raised U.S. aggregate productivity. Bell et al. (2019) argue that better allocation of talent could increase innovation.

${ }^{10}$ Some studies find that bundles of general management practices can raise firm performance (Bruhn et al. 2010, 2018; Bruhn and Zia 2013; Bloom et al. 2013a, 2020; Drexler et al. 2014; Fryer 2017; Giorcelli 2019; Iacovone et al. 2019). Other studies report limited effects (Cole et al. 2011; Karlan and Valdivia 2011; Karlan et al. 2015; Brooks et al. 2018). This suggests the effects may vary by which specific practices are adopted and by firm type, firm size, and the available human capital in the firm.

${ }^{11}$ Bennedsen et al. (forthcoming) focus on temporary CEO absences and find transient effects on firm performance. Becker and Hvide (2017) and Smith et al. (2019) focus on owner deaths and find persistent effects.

${ }^{12}$ Also related, Lazear et al. (2015) and Hoffman and Tadelis (2018) highlight the impact of middle managers on worker productivity. Nygaard (2011), Ahern and Dittmar (2012), Matsa and Miller (2013), and Eckbo et al. (2016) analyze the effects of the Norwegian gender quota for managers on firm performance. More generally, Bertrand and Schoar (2003) find evidence that there are differences in "style" across managers, while Malmendier and Tate (2005) analyze
} 
Finally, we show that the loss of the Jewish elite affected German firms and economic outcomes. Previous work has focused on universities (Waldinger 2010, 2012, 2016) and schools (AkbulutYuksel and Yuksel 2015). In Russia, the severity of the Holocaust was associated with long-run political and economic outcomes of cities and regions (Acemoglu et al. 2011; Grosfeld et al. 2013).

\section{Historical Context}

\subsection{Jews in the German Economy}

Following the partial emancipation of Jews after the Napoleonic wars and full emancipation during German unification in 1871, Jews became increasingly influential in the German economy. They founded many important firms and became leading managers in some of the largest corporations. In 1908, 22 percent of the 747 richest Prussians were of Jewish origin (Mosse 1987, p. 6). In 1928, Jews paid more than 30 percent of Berlin's municipal taxes, despite accounting for only five percent of the population (Elon 2003, p. 259). Notwithstanding occasional episodes of antisemitism, German Jews were almost entirely assimilated, especially among the economic elite. Inter-religious marriages were common in the decades before 1933. Historians have argued that one could hardly differentiate a Jewish economic elite from a non-Jewish elite during the years of the Weimar Republic (for example, Münzel 2006, p. 89).

\subsection{The Rise of the Nazi Party}

The antisemitic National Socialist German Workers' Party, commonly referred to as the Nazi Party, received only 2.6 percent of votes in the May 1928 election to the German Reichstag. In the wake of the Great Depression, the party's vote share rose to 37.3 percent in the July 1932 election. In the following election in November 1932, the Nazi's vote share declined to 33.1 percent, and many political observers predicted a gradual decline of the Nazi movement (see, for example, Enderis 1933, a New York Times article published on January 1, 1933). Despite the declining vote share of his party, a political vacuum allowed Hitler to become chancellor on January 30, 1933. In the following months and years, the Nazi government started a host of measures targeting Jews that ultimately culminated in the Holocaust.

\section{3 “Aryanizations" of Stock-Market Listed Firms}

The Nazi government did not pass any laws that explicitly forced private firms to dismiss Jewish employees before 1938. Nonetheless, many Jewish managers lost their positions as early as 1933, because of the rise of antisemitism. ${ }^{13}$ As dismissals were not guided by formal rules, the "forced

the effects of overconfident managers. We also add to the literature on micro-foundations in management strategy, which emphasizes that differences in individual human capital affect firms (Abell et al. 2008; Coff and Kryscynski 2011).

${ }^{13}$ The racist neologism "Aryanization" was coined during the 1930s. In the historical literature the term "Aryanization" is used as a synonym for the exclusion of Jews from the German economy (see Bajohr 2002, p. 11, for a discussion 
resignation of Jews from the boards of [...] enterprises [...] was a gradual process effected with widely differing degrees of dignity and consideration” (Mosse 1987, p. 376). Many listed firms exploited laws and events that did not directly affect them to remove Jewish managers. For example, the law specifying the dismissal of Jewish civil servants of April 7, 1933 applied only to managers in firms that were majority-owned by the state (Münzel 2006, pp. 126-128). Some privately owned firms nevertheless used the law as a pretext to dismiss Jewish managers.

In the following years, more and more Jewish managers were forced out of their firms. By 1938, virtually all Jewish managers had left their firms, sometimes because non-Jews saw the political situation as an opportunity to further their own careers by pushing Jews out or because Jewish managers migrated abroad to escape rising discrimination. ${ }^{14}$ Following the ordinance on the "Elimination of Jews from the German Economy" from November 12, 1938, all joint stock firms were forced to dismiss remaining Jewish board members to avoid being liquidated (Benz 1988, pp. 324).

The timing of the actual removal of the Jewish managers may have been endogenous to firm performance, as firms tend to dismiss managers when firms are performing poorly (Murphy and Zimmerman 1993; Denis and Denis 1995; Hayes and Schaefer 1999; Fee et al. 2013; Jenter and Lewellen 2017; Bell et al. 2018). We therefore use variation in the fraction of Jewish managers in 1932 as the treatment variable in our analysis.

Our newly collected data on managers in all German firms that were listed in Berlin show how the loss of Jewish managers affected firms. We find that Jews were over-represented among senior managers relative to their population share of 0.8 percent. Jews held between 15 percent and 16 percent of senior management positions in 1928 and 1932 (Figure 1). By the end of 1933, the fraction of Jewish managers had fallen by about one third. By 1938, virtually no Jewish managers remained in firms that were listed in Berlin.

of the term). In particular, the term is used for two different types of discriminatory measures against Jews: first, the removal of Jews from senior management positions in large German firms (Münzel 2006) which is the focus of our paper; and second, the forced sale or liquidation of smaller "Jewish firms" (Bajohr 2002; Kreutzmüller 2017).

${ }^{14}$ Of the approximately 522,000 German Jews, around 304,000 managed to emigrate before the beginning of World War II (United States Holocaust Memorial Museum 2017). The main destinations of Jewish managers were the United States, the United Kingdom, Switzerland, the Netherlands, and France (Münzel 2006, p. 246). Most of the rest were brutally murdered in concentration camps. Victims included the former Commerzbank executives Albert Katzenellenbogen and Ludwig Berliner and the former Leonhard Tietz AG executive Franz Baumann. Very few survived the Holocaust in Germany. 


\section{Data}

\subsection{Data on Senior Managers of Listed Firms}

\section{Data on Managers}

We construct a comprehensive new database that contains the names and characteristics of all senior managers of German firms listed on the Berlin Stock Exchange in 1932. We collect the data using a range of historical sources. The 1932 edition of Handbuch der deutschen Aktiengesellschaften contains information on the most senior managers (executive and supervisory board members) of German joint stock firms. Each stock corporation in 1930s Germany was run by two boards: the supervisory board and the executive board. Until the late 19th century, managers of the supervisory board had been the main decision makers in German firms. After a revision of commercial law in 1884, German executive board members became gradually more important (Münzel, 2006, p. 43). ${ }^{15}$ The exact division of authority between supervisory board and executive board varied across firms in the 1930s. For instance, firm founders chaired the supervisory board in some firms, while in other firms they chaired the executive board.

Our baseline measure of senior managers includes all members of both boards. We thereby ensure that we analyze the entire top management level. The average firm listed in our data employed twelve such senior managers. We extract information on top managers for all 655 firms that were listed in Berlin in 1932. The firms in our sample employed 4,873 senior managers holding a total of 7,791 positions in 1932 (Table 1). ${ }^{16}$ We collect similar data for the years 1928, 1933, and 1938 from the respective volumes of Handbuch der deutschen Aktiengesellschaften, as detailed in Data Appendix B.1.

\section{Identifying Jewish Managers}

Handbuch der deutschen Aktiengesellschaften does not report information on the Jewish origin of managers. We identify Jewish managers using multiple sources (Münzel 2006; Windolf 2011; Röder and Strauss, eds 1980; Köhler 2008) and the online database World Biographical Information System (WBIS). We hand-check all managers who do not appear in these sources by conducting an internet search to find information on their ancestry. Further details on the data collection are in Appendix B.1.

For many of the early measures against Jews, the Nazi government considered an individual to be "Jewish" if at least one grandparent had been a practicing Jew. ${ }^{17}$ We classify managers as Jewish

\footnotetext{
${ }^{15}$ In many executive boards, there were two hierarchical levels: one was composed of one or a few most senior executives (who would perform functions akin to a modern CEO, together with the chairmen of the supervisory board) and the other regular managers (who were responsible for one specific line of business or region of operation).

${ }^{16}$ Some managers held multiple positions because they could hold both executive and supervisory board positions in the same firm, or executive positions and/or supervisory positions in multiple firms.

${ }^{17}$ This rule was, for example, applied in the so-called "Law for the Restoration of the Professional Civil Service," which was passed on April 7, 1933. The law was used to dismiss all Jewish civil servants from their position. While
} 
based on this definition. The definition comprises practicing Jews, such as banker Max Warburg who was active in the Jewish community of Hamburg, and also individuals with Jewish ancestors who had converted to Christianity, such as I.G. Farben manager Carl von Weinberg. All of these managers were forced out of their firms because of their Jewish ancestry. Our data show that 423 of 4,873 managers (around 9 percent) were individuals of Jewish origin in 1932. They held 1,230 out of 7,791 manager positions (around 16 percent) (Table 1). The share of positions held by Jewish managers is consistent with data on a smaller set of firms in Windolf (2011).

\section{Characteristics of Managers}

We extract information on the characteristics of managers for the years 1928, 1932, 1933, and 1938 from the respective volumes of Handbuch der deutschen Aktiengesellschaften, as detailed in Appendix B.1.2. Overall, we collect data on 29,834 manager positions for these four years. Table 1 summarizes the manager characteristics for 1932, the year before the Nazis came to power.

While about 1 percent of the relevant age cohorts were studying at a university at the turn of the century (Windolf 1990), 36 percent of managers were educated at a university. This figure was even higher for Jewish managers, 45 percent of whom had a university education. Jewish managers were also more likely to hold a graduate degree ( 36 vs. 24 percent). ${ }^{18}$ Jewish managers were also more likely to hold the honorary title of Kommerzienrat (8.8 versus 4.3 percent). This title was granted by the German Emperor to individuals who made outstanding contributions to society. ${ }^{19}$ These numbers suggest that Jewish managers had higher general human capital than other managers.

Jewish managers had longer tenure, measured by whether they had already held a manager position in the same firm in 1928 (70.6 versus 61.8 percent). Similarly, they had more general managerial experience, measured by whether they had already held a manager position in any of the sample firms in 1928 (83.0 versus 68.3 percent).

Jewish managers were also better connected to other firms. We use data on whether managers held board positions in other firms in 1932 to measure connections. For this measure we do not only consider the 655 firms listed in Berlin, but all 4,378 stock companies with nominal capital above 500,000 Reichsmark (RM) in 1932 (see Data Appendix B.1 for details). We essentially document the complete manager network among large and medium-sized German firms. On average, managers

private firms were not forced to dismiss Jewish managers until 1938, many stock companies started to dismiss senior managers with reference to this law and to the same definition of "Jewishness" as early as 1933 (Münzel 2006, pp. 126). This approach follows the definition of the historical literature on Jews in the Germany economy (see, for example, the discussions in Mosse 1987 and Münzel 2006, pp. 80-92).

${ }^{18}$ The fraction of senior managers with a graduate degree is higher in Germany than in other countries. At present, 45 percent of board members of the largest German companies have a doctorate degree (Schmid et al. 2017).

${ }^{19}$ The title is roughly comparable to the honors system of the United Kingdom. A rigorous selection process based on wealth, income, public service, charitable activities, and standing among peers ensured that only the most successful businessmen were awarded the coveted title (for more information see Mosse, 1987, pp. 3). In 1919, the German Reich officially discontinued the awards but most individuals who had been awarded the title continued to list it in official documents. 
held 2.2 board positions in other stock companies, but Jewish managers held more than 5 such positions.

The differences between Jewish and non-Jewish managers were not driven by the types of firms that they worked for. Compared to their non-Jewish colleagues in the same firms, Jewish managers held more academic and honorary titles, had longer tenure, greater experience, and more connections to other firms (see Table 1, column 4). Overall, the statistics suggests that Jewish managers were exceptional along a number of dimensions. ${ }^{20}$

\subsection{Data on Stock Prices and Dividends}

We manually digitize stock prices from historical listings (called Börse und Wirtschaft, later Monatskursblatt Berliner Börse) of the Berlin Stock Exchange (see Data Appendix B.2.1 for details). ${ }^{21} \mathrm{We}$ record more than 240,000 daily stock prices for all German firms listed in Berlin in 1932, for the months January and July of the years 1929 to $1943 .^{22}$

Some stocks, especially those of smaller firms, were not traded every day. We therefore average stock prices in a plus and minus 10-day window around January 10th and July 10th of each year. ${ }^{23}$ Between 1929 and 1943, the stocks of some firms were consolidated. For example, Dresdner Bank stocks were consolidated on August 4, 1932, at an old-stock:new-stock ratio of 10:3. As a result, the reported stock price increased by 333 percent. We account for these consolidations by dividing all stock prices by the consolidation ratio (3.333 in our example) after each consolidation. Between 1929 and 1943, some firms issued new stocks and offered existing shareholders a subscription right to prevent stock dilution. We also adjust stock prices for mechanical drops after the deduction of subscription rights by multiplying subsequent stock prices by the corresponding adjustment factor, following standard practice (Ronge 2002, p. 58, see Appendix B.2.1 for details). The adjustments hardly affect the results.

We also collect data on dividends from the listings of the Berlin Stock Exchange and from Handbuch der deutschen Aktiengesellschaften 1935 and 1941 (see Appendix B.2.2 for details).

\footnotetext{
${ }^{20}$ Two factors may explain the exceptional characteristics of Jewish managers. First, discrimination against Jews may have been prevalent even before 1933 and thus Jews would have had to be exceptional to be hired as managers. Second, a large literature has highlighted the extraordinary human capital of German Jews and, in particular, the entrepreneurial culture that flourished in the German Jewish community (for example, Botticini and Eckstein 2007, 2012; Becker and Pascali 2019; D’Acunto et al. 2019; Koudijs and Voth 2020). The entrepreneurial spirit exhibited by many Jews contributed to the lasting success of Jews in manager-run businesses (Ziegler 2000a).

${ }^{21}$ The Berlin Stock Exchange was the largest stock exchange in 1930s Germany and one of the largest in the world. It generated about 66 percent of financial transaction tax revenue in Germany (Gömmel and Pohl 1992, p. 179). The evidence in Ferguson and Voth (2008) suggests that stock prices adjusted quickly and in predictable ways to the release of new information.

${ }^{22}$ The German banking crisis led to the closure of the Berlin Stock Exchange between September 1931 and April 12, 1932. For 1932, we therefore use stock prices for April and October. The results are robust to dropping all observations for 1932 (Appendix Table A.1, columns 1-2).

${ }^{23}$ The results are robust to averaging stock prices in a plus-minus three-day or plus-minus five-day window around January 10th and July 10th or to averaging stock prices for all of January and July (Appendix Table A.1, columns 3-8).
} 


\subsection{Data on Returns on Assets}

We record data on firms' returns on assets from the 1932 and 1941 editions of Handbuch der deutschen Aktiengesellschaften. The return on assets is defined as profits before interest payments and taxes divided by total assets. The data are for the years 1931, 1936, and 1940. Many firms do not report the financial figures that are required to calculate the return on assets. As a result, the data allow us to calculate the return on assets for 289 firms (see Appendix B.2.4 for details).

\subsection{Data on Control Variables}

We collect data on various firm-level control variables measured in 1932. We obtain connections to the Nazi Party from Ferguson and Voth (2008). The measure indicates whether any of the firms' managers made financial contributions or provided political support to Hitler, Göring, or the Nazi Party. We also collect data on nominal capital, industry classifications, and firm age from Handbuch der deutschen Aktiengesellschaften (1932). Finally, we collect data on the period during which the balance sheet is reported from Monatskursblatt Berliner Börse.

\subsection{Summary Statistics on Firms}

We present statistics for all firms (Table 2, column 1), firms without Jewish managers (column 2), and firms with at least one Jewish manager (columns 3-7). The average firm employed roughly 12 senior managers in 1932 (column 1). The average firm with at least one Jewish manager employed about three Jewish managers in 1932, corresponding to a fraction of Jewish managers of 22 percent (column 3). ${ }^{24}$

To assess preexisting differences across firms, we first compare firms without Jewish managers (column 2) to firms with at least one Jewish manager (column 3). Both types of firms were of similar age and reported their financial statements at similar times. Since Jewish managers were exceptionally qualified, the average firm with Jewish managers had more qualified managers, as measured by managers with tenure in the firm, general experience, and university education. The average firm also had more connections to other firms through their senior managers. Perhaps surprisingly, the average firm with Jewish managers was more connected to the Nazi Party, presumably because firms with highly qualified managers were more connected to politicians in general. Furthermore, the average firm with at least one Jewish manager was larger, both measured by the number of senior managers and by the nominal capital of the firm. There are two reasons for this. First, the probability of employing a Jewish manager increases mechanically with the number of managers. Second, the exceptional characteristics of Jewish managers allowed them to manage larger firms. ${ }^{25}$

\footnotetext{
${ }^{24}$ We report summary statistics by the importance of Jews for various firm-level managerial characteristics in Appendix Table A.2.

${ }^{25}$ The large difference in average nominal capital was predominately driven by two conglomerate firms: the national railroads Reichsbahn and the chemical producer I.G. Farben. Conglomerates were large firms composed of formerly
} 
Throughout our analysis, we account for differences between firms with and without Jewish managers using several approaches. First, all regressions include a full set of firm fixed effects that control for permanent differences across firms. Hence, our identification strategy does not require that firms were similar in 1932. We only assume that firms with a higher fraction of Jewish managers would have evolved in parallel to other firms had the Jewish managers not been dismissed. We present evidence in support of this assumption below. Moreover, we control for potential shocks to firms with different characteristics by using a wide range of control variables interacted with time fixed effects.

To further strengthen our identification strategy, we construct subsamples where firm characteristics are similar. We consistently find that the effects of interest do not vary in these subsamples. For instance we estimate results in a sample of firms that all had at least one Jewish manager. Conditional on having at least one Jewish manager, firms with a higher fraction of Jewish managers were similar to firms with a lower fraction of Jewish managers (Table 2, columns 4-5). The firms look particularly similar along all observable characteristics if we exclude the two conglomerate firms (Reichsbahn and I.G. Farben) that had a positive but low fraction of Jewish managers (columns $6-7)$.

\section{The Effect on the Characteristics of Firms' Senior Manage- ment}

This section presents the first set of main results. We analyze how the removal of Jewish managers affected the overall characteristics of firms' senior management. For this analysis, we use data on manager characteristics for the years 1928, 1932, 1933, and 1938. By 1938, essentially no Jewish managers remained in their firms.

Our empirical strategy compares changes in manager characteristics in firms that had employed Jewish managers in 1932 and lost them after the Nazi government took power in January 1933, to changes in firms that had not employed Jewish managers. We estimate:

$$
\begin{aligned}
& \log \left(\text { Characteristic }_{i t}\right)=\sum_{\tau=1928}^{1938} \beta_{\tau} \text { Fraction Jewish Managers }(1932)_{i} \times \mathbb{1}[t(i)=\tau] \\
&+ \text { FirmFE }_{i}+\text { YearFE } \\
& t+\epsilon_{i t} .
\end{aligned}
$$

The outcome variable is the log of a certain manager characteristic in firm $i$ in year $t$, such as the $\log$ of the number of managers with a university education in firm $i$ in year $t .^{26}$

independent companies that operated under one management in 1932. Without these two firms, the average nominal capital of firms with at least one Jewish manager was 16.4 million RM.

${ }^{26} \mathrm{~A}$ small number of firms report zeros on some of the outcome variables, so we cannot include them in specifications using the log outcome variable. Appendix Table A.3 reports robustness checks using the inverse hyperbolic sine 
Fraction Jewish Managers (1932) ${ }_{i}$ measures the fraction of Jewish managers in firm $i$ in 1932. It is interacted with indicator variables for 1928, 1933, and 1938. The interaction with the indicator for 1932 is excluded from the regression so that the coefficients are estimated relative to 1932, the last year before the Nazis came to power. FirmFE $E_{i}$ is a full set of firm fixed effects and YearFE $E_{t}$ is a full set of year effects (for 1928, 1933, and 1938). To account for potential correlation of shocks within firms across time, we cluster standard errors at the firm level.

We plot the yearly coefficients and the corresponding 95 percent confidence intervals in Figure 2. The first outcome is a measure for firm tenure, i.e., the number of managers who had been working as managers in the same firm since 1928. From 1932 to 1933, firms with a higher fraction of Jewish managers in 1932 experienced a sharp decline in the number of managers with tenure since 1928, relative to firms without Jewish managers (Figure 2, panel a). The drop continued until 1938 when virtually all Jewish managers had been dismissed. For both 1933 and 1938, the difference between firms that lost Jewish managers and other firms is statistically significant, relative to their 1932 values. This finding is not surprising, because once a manager with tenure is expelled, finding a replacement with the same length of tenure in the firm is impossible.

The second outcome is a measure for experience, i.e., the number of managers who held a manager position in any of the sample firms in 1928. Firms could have compensated for the loss of an experienced Jew by hiring a manager who had experience running another firm. Firms with a higher fraction of Jewish managers in 1932 experienced a statistically significant decline in the number of experienced managers, relative to other firms (panel b). This suggests that the firms did not replace the dismissed Jewish managers with other managers of similar experience.

We also find that firms with a higher fraction of Jewish managers in 1932 employed fewer managers with a university education after 1933 (panel c). The difference is statistically significant in 1938. Hence, firms did not replace the highly educated Jewish managers with similarly educated non-Jews.

Finally, we analyze the effect of losing Jewish managers on the number of connections of a firm. For this analysis, we consider connections between firms through senior managers. Connections are measured contemporaneously (i.e., we measure the number of connections of a firm to other listed firms in Germany in that year). Connections to other firms dropped sharply and significantly in 1933. They remained low until 1938. This shows that firms with a higher fraction of Jewish managers in 1932 could not compensate for the loss of highly connected managers after 1933.

transformation, which is an approximation to the log transformation that permits using zero values. The results are almost identical. Appendix Figure A.1 plots results including additional control variables. 
We test the robustness of the graphical analysis by estimating a differences-in-differences specification:

$$
\begin{aligned}
& \log \left(\text { Characteristic }_{i t}\right)=\beta_{1} \text { Fraction Jewish Managers }(1932)_{i} \times \text { Post } 1933_{t} \\
&+ \text { FirmFE }_{i}+\text { YearFE } \\
& t
\end{aligned}
$$

where Post $1933_{t}$ is an indicator variable that is equal to one for all years after 1932, and zero otherwise. Controls $s_{i t}$ is a vector of firm-level control variables, described in detail below. We measure all controls in 1932, and interact them with year fixed effects, to ensure the control variables cannot endogenously respond to the removal of the Jewish managers.

Table 3 presents the results for all manager characteristics, using one panel for each outcome variable. The specifications in column 1 control for firm and year fixed effects. The coefficients on the interaction of the fraction of Jewish managers in 1932 with a post-1933 indicator are negative and significant for all outcome variables, consistent with the graphical evidence. The average firm with Jewish managers in 1932 lost 22 percent of its managers after the Nazis came to power. The point estimate in column 1 of panel a implies, for example, that the average firm with Jewish managers experienced a decline in the number of managers with tenure since 1928 of approximately $18 \log$ points.

In the subsequent columns, we add several control variables: connections to the Nazi Party, whether a firm published its financial statements in January every year (coinciding with the Nazis coming to power in 1933), firm age, firm size, and industry. All controls are interacted with a full set of year fixed effects. The coefficient on the fraction of Jewish managers remains stable and significant in all columns. The results with an alternative treatment variable, a binary indicator for whether the firm had any Jewish managers in 1932, are quantitatively similar to the results using the fraction as treatment variable (Appendix Table A.4). The decrease in manager characteristics was not primarily a result of a lower total number of managers (Appendix Table A.5). This suggests that the affected firms hired other managers to replace the dismissed Jewish managers but that these managers had different characteristics. ${ }^{27}$

Taken together, the evidence shows that the removal of Jewish managers had a lasting impact on the characteristics of managers at firms that had employed Jewish managers in 1932. In 1938, these firms still had fewer managers with firm-specific tenure, general managerial experience, a university education, and fewer connections to other firms. The persistent decline in these manager characteristics up to 1938 is noteworthy, because firms had up to five years to replace the Jewish managers after 1933.

\footnotetext{
${ }^{27}$ In general, there was a significant degree of turnover in managerial labor markets. For example, 37 percent of senior managers in 1932 were not employed in the same firm in 1928.
} 
There are three possible interpretations of these results. First, managers may have all the bargaining power in wage negotiations with the firm or the managerial labor market may be perfectly competitive, with a negligible role for firm-specific human capital. In both cases, firms have to fully compensate managers for their marginal product, firm value is independent of managerial characteristics, and firms have no incentive to hire managers with similar characteristics. Under this extreme interpretation, the loss of Jewish managers would not have affected firm value.

Second, the manager characteristics we analyze may be beneficial to firm value. Tenure is likely associated with firm-specific human capital, while experience and university education are likely associated with general human capital. Connections could proxy for manager quality, since only reputable managers may be offered multiple board positions. In addition, managers with many connections could improve information flows to input providers and output customers. Firm-specific human capital generates rents for employers in standard models (Becker 1964). General human capital can benefit the employer if there are information frictions on managerial labor markets (Acemoglu and Pischke 1998; Dessein and Prat 2019). Despite the benefits, frictions on the labor market for managers may have left firms unable to adequately replace the Jewish managers. Under this second interpretation, the loss of the Jewish managers would have harmed firm value.

A third interpretation views the characteristics we analyze as detrimental to firm value. Highly educated and experienced managers may be more skilled at becoming entrenched and extracting rents from their employers (Shleifer and Vishny 1989). Managers with many connections may be busier (Fich and Shivdasani 2006) or hire less competent executives only because they are in their network (Kramarz and Thesmar 2013). This may weaken corporate governance. Even if the detrimental nature of these characteristics were known, firms may not choose to endogenously fire their managers, because firing signals to investors that the firm is performing poorly or because firing managers is costly. Under this third interpretation, firms had no incentive to hire managers with similar characteristics in place of the Jewish managers. The exogenous removal of the Jewish managers may have raised firm value.

The following section allows us to differentiate between the three interpretations. We analyze how firm stock market performance responded to the removal of the Jewish managers and whether the loss of specific manager characteristics was particularly beneficial or harmful to firm performance. 


\section{The Effect on Stock Prices}

\subsection{The Average Effect on Stock Prices}

We investigate the effect on stock prices with the following specification:

$$
\begin{aligned}
\log \left(\text { Stock Price }_{i t}\right) & =\sum_{\tau=1929.0}^{1943.5} \beta_{\tau} \text { Fraction Jewish Managers }(1932)_{i} \times \mathbb{1}[t(i)=\tau] \\
& + \text { FirmFE }_{i}+\text { TimeFE }_{t}+\beta_{c} \text { Controls }_{i t}+\epsilon_{i t} .
\end{aligned}
$$

The specification is similar to the previous section, but uses the log of the stock price as the outcome variable. $^{28}$ As explained in Section 2, we have two observations of the stock price for each firm $i$ per year, around January 10th and July 10th. The data cover the years from 1929 to $1943 .{ }^{29} \mathrm{We}$ exclude January 10, 1933 as the last observation before Hitler became Chancellor on January 30, 1933. We plot the estimated coefficients $\beta_{\tau}$ and the 95 percent confidence intervals in Figure 3. Panel a shows the coefficients of a specification with a full set of firm and time fixed effects. Panel $\mathrm{b}$ plots the coefficients of a specification that further controls for connections to the Nazi Party, reporting period, firm age, nominal capital, and industry fixed effects, all measured in 1932 and interacted with a full set of time fixed effects. ${ }^{30}$

The main identifying assumption is that the stock prices of firms with a higher fraction of Jewish managers in 1932 would have followed the same trend as the stock prices of firms without Jewish managers, if Jewish managers had not been expelled from their firms. Before January 1933, the coefficients on the fraction of Jewish managers are small and not significantly different from zero. This indicates that firms with a higher fraction of Jewish managers were not exposed to different shocks before 1933, in line with our identification assumption.

After January 1933, the trends diverged. The stock price of the average firm with a higher fraction of Jewish managers started to decline sharply, compared to the stock price of a firm without

\footnotetext{
${ }^{28}$ This section focuses on stock price changes, without incorporating dividends into the analysis. We find a negative effect of losing Jewish managers on dividends separately in Section 6. In an additional robustness check, we adjust the stock prices for dividends, assuming that investors immediately reinvest the dividend into the stock (see Appendix B.2.3 for details). The adjustment means that the coefficients measure the effect of losing Jewish managers on the return of investing (on January 10,1933) into the average firm with Jewish managers in 1932, relative to investing into a firm without Jewish managers in 1932. We use the adjusted stock prices to construct Appendix Figure A.2. The pattern over time is almost identical to Figure 3. The point estimate corresponding to Table 4, column 6 using the adjusted stock prices is $-0.474(0.152)$. The more negative coefficient is consistent with the finding that firms that lost Jewish managers paid out lower dividends after 1933.

${ }^{29}$ As we have two observations per year, the data contain 30 time periods. Time fixed effects refer to January 10th and July 10th of each year (i.e., there are two time fixed effects per year).

${ }^{30}$ The industry classifications are: financial services; insurance; transport; mining/iron/steel; machinery/electronics; construction/stones/earth; textile/clothing; chemistry/paper/wood; food/drinks; and other (consisting mainly of retail/trade/energy provision). The results are robust to using finer industry classifications (Appendix Table A.6).
} 
Jewish managers. ${ }^{31}$ The estimated short-run effect of losing Jewish managers is close to the initial stock price responses to prominent manager exits in recent times. For example, after Apple CEO Steve Jobs took permanent medical leave in 2011, the Apple stock fell by 6 percent (BBC 2011). When Fiat Chrysler CEO Sergio Marchionne stepped down due to surgery in 2018, the Fiat Chrysler stock lost 5 percent (Reuters 2018).

The effects of losing Jewish managers persisted until the end of our stock sample period. The specification with the full set of controls suggests that in July 1943, ten years after the Nazis had come to power, the stock price of an average firm that had employed Jewish managers in 1932 (which lost 22 percent of its managers) was still 11.6 log points below that of a comparable firm that had not employed any Jewish managers. The individual point estimate for July 1943 is significantly different from zero at the 1 percent level, as are all the point estimates from July 1933 onward. The results are similar with and without the controls, strengthening the view that firms with Jewish managers were not on fundamentally different trends from other firms, except for losing Jewish managers.

We also estimate results with a differences-in-differences specification:

$$
\begin{aligned}
\log \left(\text { Stock Price }_{i t}\right) & =\beta_{1} \text { Fraction Jewish Managers }(1932)_{i} \times \text { Post } 1933_{t} \\
& + \text { FirmFE }_{i}+\text { TimeFE }_{t}+\beta_{c} \text { Controls }_{i t}+\epsilon_{i t}
\end{aligned}
$$

The regressor of interest is the fraction of Jewish managers in 1932, interacted with an indicator for the months after January 1933. The point estimate in the specification with only firm and time fixed effects is significant at 1 percent (Table 4, column 1). The point estimate indicates that after the Nazis came to power, the stock price of the average firm that had employed Jewish managers (where 22 percent of managers were Jewish) was $10.3 \log$ points $\left(0.469 * 0.22{ }^{*} 100=10.3\right)$ lower after 1933, compared to the stock price of firms that had not employed any Jewish managers.

The addition of control variables hardly affects the coefficient. Each control is measured in 1932, before the rise of the Nazi government, and interacted with a full set of time fixed effects. Because the Nazi government may have favored some firms after 1933, we add an indicator for firms closely connected to the Nazi Party (column 2). We control for whether a firm published its financial statements in January. The timing of financial reporting matters because the Nazis

\footnotetext{
${ }^{31}$ The stock price of the average firm with Jewish managers experienced a relative decline of 7.1 log points between January and July 1933 (Figure 3, panel b). The sharp relative decline is consistent with the timing of events described in the historical literature. For example, Münzel (2006) documents that "from the very start" of the Nazi reign there was "radical pressure on elite managers of Jewish origin," with "more than a third of Jewish executives losing their positions" by July 1933 . Similarly, our manager data show that the average firm lost 34 percent of the Jewish managers in 1933. The point estimate on the stock price in July 1933 amounts to 51 percent of the July 1938 point estimate. The difference between the fraction of managers lost and the drop in stock prices may be explained by the sharp decline in the number of connections in 1933, as documented in Figure 2. We show that losing connected managers led to larger effects in Section 4.2 below. In Appendix Figure A.3, we document that German stock prices were generally rising after 1933, but that they were rising less quickly in firms with a higher fraction of Jewish managers in 1933.
} 
came to power on 30 January, 1933, and firms that published their statement after January may have experienced more stock price volatility (column 3). We also control for firm age (column 4) and firm size measured by nominal capital (column 5), since the asset pricing literature has shown that the stocks of young (Pástor and Veronesi 2003) and small (Fama and French 1992) firms often perform differently. Finally, we control for industry fixed effects (column 6). They account for potential shocks that may have hit specific industries. These checks offer further evidence that differential exposure to other shocks cannot explain the effect of losing Jewish managers. The results are quantitatively similar and significant using as treatment variable a binary indicator for whether the firm employed any Jewish managers in 1932 (Appendix Table A.7).

By comparing the 1932 and 1933 editions of Handbuch der deutschen Aktiengesellschaften, we can identify which firms lost some of their Jewish managers already in 1933 and which firms lost Jewish managers only after 1933. We estimate how this differential timing affected stock prices. Firms that lost some of their Jewish managers in 1933 experienced relatively lower stock prices in 1933 (Appendix Table A.8, first row of coefficients). In the following years, when these firms lost the remaining Jewish managers, their relative stock price declined somewhat further (second row of coefficients). Firms that lost all their Jewish managers after 1933 experienced no relative decline in stock prices in 1933 (third row of coefficients), but experienced lower stock prices after 1933 (fourth row of coefficients). This suggests that the sharp relative decline in stock prices in 1933 (seen in Figure 3) was entirely driven by firms that lost managers in 1933. Of course, this result should be interpreted with caution, since Jewish managers may have left their firms for endogenous reasons. For this reason, we use the fraction of Jewish managers in 1932 as the treatment variable in the baseline specifications. This measure is immune to the endogenous timing of manager separations. ${ }^{32}$

The effects of losing Jewish managers on stock prices were persistent, just like the effects on the characteristics of firms' senior management found in the previous section. The stock price results support the view that firms had gained rents from employing the Jewish managers, and, hence, that the managers' salaries did not reflect their marginal contribution to their firms' market value. Frictions in the labor market presumably left firms unable to replace managers with certain characteristics, and this persistently lowered their stock market valuation.

We carry out several robustness checks. The effects are stable and significant in a sample of firms that all employed at least one Jewish manager in 1932 (Appendix Table A.9). In this sample, the observable characteristics of firms with a higher fraction of Jewish managers were similar to firms with a lower fraction of Jewish managers, especially if we additionally exclude the two

\footnotetext{
${ }^{32}$ Our data on the composition of firm management cover the years 1928, 1932, 1933, and 1938. We can therefore explore the exact timing of dismissals by investigating changes between 1932 and 1933 but not for the subsequent years until 1938. By 1938, virtually all Jewish managers had left their firms (Figure 1, last bar). While the results suggest that the stock market reacted sharply to the timing of dismissals for the first wave of dismissals, the later dismissals may have been more anticipated and, hence, the dismissal of all Jewish managers seems to have been priced in by 1937 (see Figure 3, panel b).
} 
conglomerate firms from the sample (see Table 2, columns 6-7). The results are also robust to controlling for firm size in various ways, to restricting the sample to regularly traded firms, to dropping observations in 1932 during the German banking crisis, and to limiting the sample to firms that were never delisted (see Appendix C for details).

\section{Heterogeneity: When Do Managers Matter?}

In additional results, we show that managers are more important in competitive industries. We construct a firm-level measure of membership in cartels using data from Handbuch der Deutschen Aktiengesellschaften (see Appendix B.4). In the sample of firms that do not belong to a cartel, the point estimates are larger than the main results and significant at the 1 percent level. In the sample of firms that are members of at least one cartel, the point estimates are smaller and not significant at conventional levels (Appendix Table A.10). ${ }^{33}$

We also find that a wider cadre of senior managers affects firm performance, not just managers in chief positions. We define managers in chief positions to be the top hierarchical level of the executive board and the chairmen of the supervisory board (i.e., managers performing functions akin to a modern CEO). The remaining board members are regular managers. The point estimates for losing managers in both types of positions are statistically different from zero, of similar magnitude, and not statistically different from each other (Appendix Table A.12). The results are consistent with Bender et al. (2018). Managerial human capital could matter because it may be hard to replace the unique leadership ability of individual managers or because qualified managers cultivate organizational practices (Dessein and Prat 2019).

\subsection{The Effect of Managers with Certain Characteristics on Stock Prices}

To investigate whether the loss of specific managerial characteristics was responsible for the decline in stock prices, we estimate:

$\log \left(\right.$ Stock Price $\left._{i t}\right)=\beta_{1} \cdot \mathbb{1}[0<\text { Importance of Jews for Managerial Characteristic }(1932)<0.20]_{i} \times$ Post $1933_{t}$

$+\beta_{2} \cdot \mathbb{1}[0.20 \leq \text { Importance of Jews for Managerial Characteristic }(1932)<0.80]_{i} \times$ Post $_{1933_{t}}$

$+\beta_{3} \cdot \mathbb{1}[0.80 \leq \text { Importance of Jews for Managerial Characteristic (1932) }]_{i} \times$ Post $1933_{t}$

+ FirmFE $_{i}+$ TimeFE $_{t}+\beta_{c}$ Controls $_{i t}+\epsilon_{i t}$.

As before, the outcome variable is the log stock price. The three main explanatory variables are indicators for whether Jewish managers were responsible for 1) less than 20 percent, 2) 20 to 80

\footnotetext{
${ }^{33}$ The loss of managers should disproportionately affect firms where managerial skill is an important input into the production process. We identify an industry's dependence on managers by calculating the share of middle- and upper-level managers in an industry out of all employees, using data from the 1933 census. The share ranges from 0.03 to 2.28 percent. The results suggest that industries where managers are more important were more affected by losing Jewish managers (Appendix Table A.11).
} 
percent, or 3) more than 80 percent of a given characteristic of firm managers (such as connections to other firms or the number of educated managers). All characteristics are measured in 1932. The three indicator variables are interacted with an indicator for the months after January 1933. If a firm did not have any Jewish managers in 1932, the three indicator variables are zero. Hence, the coefficients on the three indicator variables are estimated relative to firms that did not employ any Jewish managers in $1932 .{ }^{34}$

We start by analyzing managers that were important in connecting their firm to other firms. To identify connections, we use data on whether managers held board positions in other firms in $1932 .{ }^{35}$ We define a measure that captures the importance of connections formed by Jewish managers, relative to connections formed by other managers. If firm $i$ had connections to $N_{i}$ other firms and Share Jewish Connector $s_{i j}$ was the share of connections between firms $i$ and $j$ formed by Jewish managers $(i \neq j)$, we define:

$$
\text { Importance of Jews for Managerial Connections }(1932)_{i}=\frac{\sum_{j} \text { Share Jewish Connectors }(1932)_{i j}}{N_{i}} .
$$

This measure is the share of firm $i$ 's connections that were formed by Jewish managers, averaged over all firms that were connected to firm $i .^{36}$ The measure is based on the theoretical networks literature (Jackson 2010). It captures the influence of Jewish managers on the degree centrality of the firm.

After 1933, stock prices declined by 3.4 log points (not significant) for firms where Jewish managers made up less than 20 percent of the firm's connections in 1932, relative to firms without Jewish managers (Table 5, column 1). Stock prices declined by 17.9 log points (significant at 1 percent) in firms where the Jewish managers were responsible for 20 percent to less than 80 percent of the firm's connections, and by 25 log points (significant at 5 percent) in firms where the Jewish managers were responsible for more than 80 percent of the firm's connections, relative to firms without Jewish managers in 1932. The results suggest that firms that lost a large share of their connections suffered larger declines in stock prices. In line with other work, these findings imply

\footnotetext{
${ }^{34}$ We do not use observed changes in managerial characteristics as regressors, since observed changes are endogenous to firm performance.

${ }^{35}$ We measure connections to 4,378 German stock corporations. These corporations were listed in Berlin and/or had nominal capital of at least 500,000 RM. 7 firms listed in Berlin had nominal capital below 500,000 RM. The majority of German stock corporations were not listed on any stock market and rarely traded.

${ }^{36}$ To be clear, consider the simple example in Appendix Figure A.4. Firm A had four managers. Managers 1 and 2 were Jewish. Manager 1 was connected to firm B; managers 2 and 3 to firm C; and manager 4 to firm D. Hence, the firm had 3 connections overall, i.e., $N_{i}=3$. Jewish managers were responsible for the full link to firm B, 0.5 of the link to firm $\mathrm{C}$, and 0 of the link to firm D. Hence, for firm A:
}

$$
\text { Importance of Jews for Managerial Connections }(1932)=\frac{(\overbrace{1}^{\text {Firm B }}+\overbrace{0.5}^{\text {Firm C }}+\overbrace{0}^{\text {Firm D }})}{3}=0.5 \text {. }
$$

Firm A would fall in the middle category where Jewish managers were responsible for $\geq 20$ percent but $<80$ percent of the firm's connections. 
that social capital matters for firm outcomes, and that it is hard to replace well-connected managers (Glaeser et al. 2002; Cai and Szeidl 2018; Haselmann et al. 2018). ${ }^{37}$

Next, we study the effect of managers with a university education. After 1933, stock prices declined by $5.2 \log$ points (not significant) in firms that had Jewish managers in 1932 but where Jewish managers were not responsible for more than 20 percent of the firm's managers with a university education (Table 5, column 3). Stock prices declined by 21.4 log points (significant at 1 percent) in firms where the Jewish managers made up 20 percent to less than 80 percent of the firm's managers with a university education, and by 62.3 log points (significant at 1 percent) in firms where the Jewish managers made up more than 80 percent of the firm's managers with a university education. The results indicate that firms that had a large share of Jewish managers among their highly educated managers suffered larger declines in stock prices. The results on managerial connections and education are robust to the inclusion of additional control variables (Table 5, columns 2 and 4).

Last, we study the effect of managers with experience since 1928. The specification without controls suggests there is a larger effect for firms that had a larger share of Jewish managers among their experienced managers (Table 5, column 5). However, the inclusion of the control variables renders the coefficients for different shares of experienced managers similar (Table 5, column 6). For example, the point estimate on firms where over 80 percent of experienced managers were Jewish is statistically insignificant and of similar magnitude to the point estimate on firms where less than 20 percent of experienced managers were Jewish. This suggests that experienced managers were less important for firm performance. ${ }^{38}$

To compare the effect of different manager characteristics more conclusively, we also estimate specifications that simultaneously include the indicator variables for all three characteristics. These specifications estimate the effect of one characteristic, while keeping constant the other characteristics. Therefore, the results account for potential correlations between different characteristics. For example, managers with many connections may also have been more educated. The estimates are of similar magnitude compared to the previous specifications (Table 5, columns 7-8). The coefficients on connections and education are statistically significant with and without controls. The coefficients on larger shares of experienced managers are statistically insignificant with and without controls. This implies that the earlier results did not rely on spurious correlations between the different managerial characteristics. ${ }^{39}$

\footnotetext{
${ }^{37}$ The indicator variables could simply proxy for firms that had a high fraction of Jewish managers in 1932 . To rule out this concern, we estimate specifications that include the fraction of Jewish managers in 1932 among the regressors, in addition to the three indicator variables. The coefficient on the fraction is statistically insignificant and positive, while the coefficients on the indicator variables remain at the same significance levels and of similar magnitude to the results presented in this section.

${ }^{38}$ In unreported specifications, we separately examine tenure in the same firm and experience in other firms. We find little evidence that firm-specific tenure or experience in another firm affected stock prices.

${ }^{39}$ In unreported results, we vary the definition of the explanatory variables that indicate greater managerial characteristics. For example, we use 25 and 75 percent as the cutoffs, or 50 percent. In all these specifications, the point
} 
Overall, the results suggest that managers who connect to other firms and managers with university education significantly contribute to firm value. The findings are consistent with the view that connections and education are positively correlated with managerial human capital. There is no evidence that experienced managers affect market value, as long as managerial experience is not correlated with connections and the education level of managers. This finding could indicate that the positive effects of experience on firm-specific human capital are outweighed by the negative effects of experience through rent-seeking and entrenchment.

The coefficients on firms where Jewish managers were responsible for less than 20 percent of all three managerial characteristics are positive, close to zero, and statistically insignificant (columns 7 and 8). Hence, losing Jewish managers per se had no significant effect on stock prices. This is a key finding, which validates our identification strategy. It indicates that firms with Jewish managers in 1932 and firms without Jewish managers in 1932 remained on parallel trends after 1933, unless Jewish managers were responsible for a large share of the firm's connections or educated managers.

\section{The Importance of Managerial Connections}

The data allow us to investigate the role of managerial connections in more detail. Our main measure of connections, degree centrality, may potentially miss interesting aspects of the German firm network. We therefore analyze other network measures (Katz centrality, eigenvector centrality), which capture higher order links between firms (Katz 1953; Bonacich 1987; see Appendix D for details). The results indicate that changes in direct connections that were caused by the removal of Jewish managers had large effects on stock prices. In contrast, changes in higher order connections were less important (Appendix Table A.13). ${ }^{40}$

Moreover, we find that connections to both banks and non-banks affected firm performance (Appendix Table A.14). The results are consistent with the view that losing managers with direct relationships to banks harms access to finance, but that relationships to non-financial firms are of similar importance.

\section{The Importance of Managerial Education}

We also inspect different types of university education in more detail. Stock prices only declined if firms had employed a higher share of Jewish managers with a graduate degree, but not if the managers only had a basic university degree. This suggests that upper-tail managerial human capital is particularly important for firm performance (Table 6, columns 1 and 2).

estimates on a large share of connections and university education are negative, while the point estimates on any share of experienced managers are small and mostly positive.

${ }^{40}$ Information flows along upstream or downstream production chains may be easier when managers have direct connections, consistent with evidence in Cai and Szeidl (2018). In contrast, indirect information flows through multiple nodes of the firm network seem less important. Such indirect information pass-through may have some importance in networks of small microfinance firms (Banerjee et al. 2013), but may be less relevant for large listed corporations. 
Stock prices in all types of industries declined if firms had employed a higher share of Jewish managers with a graduate degree in social sciences (for example, law, economics, business, and history; see Appendix B.1.2 for details on the field of study of managers). This suggests that knowledge related to commercial transactions and human interactions is an important part of managerial skill, independent of firm type. In contrast, we find that losing managers with graduate degrees in STEM subjects (for example, engineering and chemistry) mainly affected firm performance in STEM-related industries, such as pharmaceuticals or machinery production, but not in non-STEM industries, such as banking and insurance (Table 6, columns 3 and 4).

\subsection{Alternative Explanations for the Effect on Stock Prices}

The results in the previous subsections indicate that the removal of connected and educated Jewish managers led to declines in firms' stock prices. In this section, we explore whether firms with Jewish managers suffered from other shocks after 1933 that were correlated with the fraction of Jewish managers in 1932. We consider two types of shocks: those resulting from other discriminatory measures against Jews, and those arising from other shocks to the demand for the products of some firms.

\subsubsection{Other Discrimination Against Jews}

\section{Effect in a Sample of Firms Favored by the Nazi Government}

Other discriminatory measures against Jews in Nazi Germany may have disproportionately affected firms with a higher fraction of Jewish managers. In a first test, we restrict the sample to firms that were favored by the Nazi regime. It is likely that these firms were not exposed to repressive measures, but rather experienced political support after 1933. We identify firms favored by the Nazi government based on three criteria. First, we include firms with managers who made financial contributions or provided political support to Hitler, Göring, or the Nazi Party before 1933 (for example, insurance company Allianz or the car manufacturer Daimler Benz). This measure was developed by Ferguson and Voth (2008). Second, we include firms that were granted forced labor workers by the Nazi government (for example, I.G. Farben). The measure is based on the "Catalogue of Camps and Prisons in Germany and German-occupied Territories 1939-1945." Third, we exclude firms that the German public or the Nazi government perceived as "Jewish" (see below for the definition of "Jewish" firms). Overall, this sample includes 171 firms that were favored by the Nazis. Despite the fact that this sample of firms is much smaller than the full sample, the effect of losing Jewish managers remains significant at the 5 percent level in the specification with all controls (Table 7). Hence, losing Jewish managers affected stock prices even in a sample of firms that were not negatively exposed to government repression. 


\section{Discrimination Against Firms Perceived as "Jewish"}

In a second test, we analyze firms that were associated with Judaism more generally. Such firms may have suffered after the Nazis came to power, for example because of antisemitic measures by the government or because they suffered from consumer boycotts. We identify firms that contemporaries explicitly named as "Jewish firms," using a range of historical sources about Jews in Germany (Bruer 1927; Landsberg 1927a,b; Priester 1927; Mosse 1987). ${ }^{41}$ Many of these "Jewish firms" had a Jewish founder, such as the department store Leonhard Tietz, founded by the Jewish merchant of the same name, or one of the world's largest electrical companies Allgemeine Electricitätsgesellschaft, founded by the Jewish industrialist Emil Rathenau. ${ }^{42}$

We separately analyze the evolution of the stock prices of "Jewish firms" (Table 8). We find negative but insignificant coefficients for "Jewish firms" after 1933 (columns 1-2). The pattern becomes clearer when we separately consider the period after 1935 . The stock prices of "Jewish firms" hardly changed in 1933 and 1934, but declined significantly after 1935 (columns 3-4). These findings are consistent with historical accounts: During the early years of Nazi rule, large "Jewish firms" were not harmed by the government because the Nazis wanted to boost employment and did not target firms that were vital for the economic recovery (James 2001, p. 38). After passing the Nuremberg racial laws in 1935, however, the Nazi government explicitly began to target large firms perceived to be Jewish (Barkai 1990, p. 83; Strauss 1999, p. XVII; James 2001, p. 38).

Importantly, controlling for "Jewish firms" does not affect the post-1933 coefficient on the fraction of Jewish managers in 1932 (Table 8, columns 5-6). These results indicate that "Jewish firms" indeed suffered in Nazi Germany, but that the effect on "Jewish firms" was orthogonal to the effect of losing Jewish managers.

To further explore the development of "Jewish firms" over time, we run a specification akin to equation 3 and additionally include an indicator for "Jewish firms," interacted with a full set of time fixed effects. Stock prices of "Jewish firms" remained constant until January 1935, then started to decline, reached their lowest point in 1939, and fully recovered by 1943 (Appendix Figure A.6). The recovery of stock prices of "Jewish firms" suggests that discriminatory measures against these firms had only temporary effects, which lasted until they were taken over by non-Jews and were no longer associated with Judaism. In contrast, the stock prices of firms that lost Jewish managers remained persistently low, even after all Jewish managers had left their firms by 1938.

Taken together, these findings imply that the effect of losing Jewish managers cannot be explained by other shocks that hit "Jewish firms." This is hardly surprising. Many firms happened

\footnotetext{
${ }^{41}$ As the historical sources only cover certain industries, we augment the definition of "Jewish firms" with the definition of "Jewish firms" in Mosse (1987), the standard reference on Jews in the German economy. All results hold if we focus on the definition that relies only on the contemporary sources.

${ }^{42}$ The average fraction of managers with Jewish origin was higher in "Jewish firms" compared to other firms (24 versus 13 percent), but there was significant variation in both groups. The 1st to 99th percentile range of the fraction of Jewish managers was 0 to 62 percent for "Jewish firms," and 0 to 57 percent for other firms.
} 
to employ managers of Jewish origin (for example, BMW, Deutsche Reichsbahn, or I.G. Farben) but they were not perceived to be "Jewish" in any way by the Nazis or the public, and hence unlikely to face direct repression or shocks to demand.

\section{Discrimination Against Lower-Ranked Jewish Employees}

In a third test, we explore whether the discrimination against Jewish managers was correlated with discrimination against lower-ranked Jewish employees. There are no consistent data on the number of lower-ranked Jewish employees for firms listed in Berlin. We therefore collect data on the share of Jews among lower-ranked employees from historical statistics published by the German Statistical Agency (Statistisches Reichsamt, see Appendix B.5 for details). These data are based on the 1933 census and report the fraction of Jews by sector (manufacturing or services) and region or large city (for example, Berlin, Hamburg, Breslau, Königsberg). Whenever we are able to use the city-level information, we do so (for about 33 percent of the sample). Otherwise, we use regional information.

The data allow us to estimate the effect of losing Jewish managers for firms in region-sector cells with very low fractions of lower-ranked Jewish employees (Appendix Table A.15). We analyze firms in region-sector cells with the lowest quartile of Jewish blue collar workers (columns 1-2), the lowest quartile of lower-ranked Jewish white collar workers (columns 3-4) ${ }^{43}$, and the lowest quartiles of both measures of lower-ranked Jewish employees (columns 5-6). In the sample using both measures, the percentage of Jews is only 0.22 percent among blue collar workers and 0.02 percent among lower-ranked white collar workers (Appendix Figure A.7). In contrast, the fraction of Jewish managers remains at 10.7 percent (compared to 13.8 percent in the full sample). In all specifications, the effect of the fraction of Jewish managers remains of similar magnitude and significant. These results suggest that the underperformance of firms that lost Jewish managers was not predominantly driven by a reduction in the supply of lower-ranked Jewish employees.

\section{Discrimination Against Jewish Shareholders}

In a fourth test, we explore the role of Jewish shareholders. There is no complete register of shareholders for this time period, but Handbuch der deutschen Aktiengesellschaften 1932 lists large shareholders for the firms in our sample. For example, the industrial property developer Königstadt AG lists two large shareholders: Bank für Brau and the Jewish private bank Gebrüder Arnhold. We identify all Jewish individuals or firms (such as Jewish private banks) that were large shareholders in any of the sample firms. ${ }^{44}$

\footnotetext{
${ }^{43}$ Lower-ranked white collar workers do not contain the senior managers that are the focus of our analysis because high-level white color workers are separately listed in the census data.

${ }^{44}$ We classify firms as having a large Jewish shareholder if an individual shareholder was of Jewish origin (as defined in Section 2.1), if an institutional shareholder was perceived as a "Jewish firm" (as defined in Section 4.3.1), or if the institutional shareholder was Jewish private bank (as listed in Köhler 2008).
} 
The results are robust in a sample of firms without large Jewish shareholders in 1932 (Appendix Table A.16). This implies that "fire sales" of large blocks of stocks by Jewish shareholders do not affect the estimated effect of losing Jewish managers. This finding is consistent with the historical literature, which suggests that Jewish private banks and other Jewish shareholders were not able to sell their stocks, but that their stock portfolios were mostly seized and redistributed as a whole. ${ }^{45}$

\section{Discrimination by Retail Customers}

In a fifth test, we consider potential discrimination by retail customers that may have been correlated with the fraction of Jewish managers. Antisemitic customer boycotts disproportionately hit retail firms. In a sample of non-retail firms, the results are similar to the baseline results (Table 9, columns 1-2). This suggests that customer discrimination cannot explain why firms with Jewish managers experienced declines in stock prices.

\subsubsection{Correlated Demand Shocks (Not Directly Related to Discrimination)}

\section{Rearmament and Infrastructure Spending}

Next, we explore whether demand shocks that were not directly caused by discrimination against Jews disproportionately affected firms with a higher fraction of Jewish managers. Soon after gaining power, the Nazi government started massive rearmament and infrastructure programs. Armament spending increased from about 0.8 billion RM in 1932 to 30 billion in 1939 (Carroll 1968). Infrastructure spending focused on war-related construction: strategic roads (the famous Autobahn), airfields, and waterways (Tooze 2008, p. 45). To test whether armament and construction spending drives the effects, we exclude all firms that the Reichswehr had identified as important for rearmament (Table 9, columns 3-4) ${ }^{46}$; firms in the war-related industries iron and steel production, machine tools, and chemicals (Table 9, columns 5-6); and construction firms (Table 9, columns 7-8). Despite dropping large shares of the sample, the coefficients remain similar to the baseline effect.

\section{Reduced Demand by International Customers}

We consider whether lower demand from abroad may have disproportionately hit firms with a larger fraction of Jewish managers. International customers or trading partners may have been

\footnotetext{
${ }^{45}$ Recently, Ihlow and Jackwerth (2020) adopt a similar approach to analyzing Jewish shareholders. They use shareholder data from the Handbuch and find no effect of Jewish shareholders on stock prices, just as we do. In contrast to our paper, Ihlow and Jackwerth (2020) use less detailed manager data and analyze only a small share of firms managed by individuals of Jewish origin. For instance, they do not observe any manager characteristics, which makes it difficult to study the effects of managerial human capital. Moreover, historians (Münzel 2006; Windolf 2011) and our data show that roughly 400 firms (60 percent) listed in Berlin had a Jewish manager, while Ihlow and Jackwerth (2020) identify only 91 such firms. Despite these differences, the results in Ihlow and Jackwerth (2020) are consistent with our conclusions. Specifically, both Ihlow and Jackwerth (2020) and we find that stock prices of firms with Jewish managers, but not with Jewish shareholders, fell after 1933 (Appendix Table A.16).

${ }^{46} \mathrm{We}$ exclude firms using a list of suppliers that the Reichswehr had identified as important for rearmament production (Hansen 1978). Anlage Nr. 6, pp. 217 reports firms that prepared for the production of armament material in 1927/28. Anlage Nr. 10, pp. 226 reports firms that were important providers of inputs for armaments production in 1931.
} 
less willing to work with firms that had dismissed their Jewish managers. Handbuch der deutschen Aktiengesellschaften 1932 includes a written narrative about each firm. We code international firms as those firms that reported "imports," "exports," or "foreign activity" as part of their business activities. For example, the brewery Dortmunder Actien-Brauerei reported "beer export: to Holland, France, Belgium, and overseas" among its business activities. The coefficient on losing Jewish managers remains stable in a sample of firms without international business activities (Table 9, columns 9-10).

\section{Firm-Specific Demand Shocks}

Finally, we investigate whether firm-specific product demand shocks may have disproportionately hit firms with a higher fraction of Jewish managers. Handbuch der deutschen Aktiengesellschaften 1941 provides narrative histories that describe each firm's development between 1933 and 1941, including discussions of product demand. We carefully read the narrative of each firm and identify all positive or negative demand shocks. For example, the entry for the storage and transport company Königsberger Lagerhaus describes that a record agricultural yield in Eastern Germany increased demand for its services. In the opposite direction, harsh winters in certain parts of Germany reduced construction and therefore demand for the cement producer Breitenburger Portland-Cement. Other demand shocks were caused by public policy. For example, the local government made the river Donau between Ulm and Kelheim more easily navigable by ship, which benefited the shipping company Rhein-Main-Donau A.-G. The coefficient on losing Jewish managers remains stable and significant in a sample of firms without firm-specific demand shocks between 1933 and 1941 (Table 9, columns 11-12).

\section{The Effect on the Aggregate Market Valuation of Listed Firms}

A back-of-the-envelope calculation allows us to estimate the aggregate decrease in market valuation of firms listed in Berlin due to the loss of Jewish managers. The calculation relies on the assumption that firms without Jewish managers were not affected by the removal of Jewish managers from other firms, i.e., we assume no spillover effects. Positive spillovers may exist because firms without Jewish managers could have taken over market share from firms in their industry that lost Jewish managers. Negative spillovers may exist in the form of reduced productivity spillovers among firms in the same industry, lower regional aggregate demand, or because firms that had employed Jewish managers poached managers from unaffected firms.

We explore the plausibility of the assumption of no spillovers by testing for spillovers within

industries and within regions. We estimate regressions based on versions of equation 4 and report the results in Appendix Table A.17. The regressors of interest include the original regressor (the 
firm's fraction of Jewish managers) and the average fraction of Jewish managers in all other firms in the industry or the region, all interacted with an indicator for the months after January 1933. While the coefficients on the firm's fraction of Jewish managers are stable and statistically significant, the coefficients on the industry- and region-level fractions of Jewish managers are all insignificant and negative. There is no evidence that positive spillovers played an important role. If anything, the negative coefficients suggest that spillovers amplified the negative firm-level effects of removing the Jewish managers. Papers by Moretti (2010), Greenstone et al. (2010), Bloom et al. (2013b), and Huber (2018) similarly suggest that spillover effects tend to amplify the effects of firm-level shocks. Negative spillovers would imply that the following calculation underestimates the aggregate loss to the German economy.

The aggregate market capitalization of firms in the sample was approximately 20.1 billion RM, based on the market capitalization of firms from January 1933 or the closest available month before January 1933. The average fraction of Jewish managers for all firms in the sample was 0.14 in 1932 (Table 2). The point estimate for the effect of the fraction of Jewish managers in 1932 on the average $\log$ stock prices after 1933 is -0.46 (Table 4, column 6). This implies a decrease of 36.87 percent $\left(=100 \cdot\left[e^{-0.46}-1\right]\right)$ if a firm lost all its managers. Multiplying the percentage decrease with the average fraction of Jewish managers results in a 5.16 percent $(=-36.87 \cdot 0.14)$ decline in the stock price of the average firm. Multiplying this average decline with the total market capitalization in January 1933 gives an approximate loss of market valuation of 1.04 billion $(=0.0516 \cdot 20.1)$ RM due to the stock price decrease. German gross national product in 1933 was 58.4 billion RM (Räth 2009), so the stock price drop due to the removal of the Jewish managers reduced the market valuation of firms by 1.78 percent of the gross national product. This number is likely an underestimate of the aggregate loss to the German economy due to aggregate antisemitic discrimination, since the expulsion of Jews affected the economy through more channels than just the loss of managers in firms listed on the Berlin Stock Exchange.

\section{The Effect on Dividends and Returns on Assets}

In this section, we assess how the loss of Jewish managers affected additional measures of firm performance. The first measure is the dividend paid to investors. Together with stock price changes, the dividend determines the return of a stock. The dividend also conveys information about firm profitability, since it is usually paid out of firm profits. We use annual data on dividends of all 655 firms in our sample for the years 1929 to 1943 (see Section 2.2 for details). The dividend is reported as a percentage of the nominal stock value. We estimate specifications equivalent to equation 4 , using dividends as the dependent variable. As the dividend is reported at yearly intervals, we replace the time fixed effects with year fixed effects. 
Firms that lost a higher fraction of Jewish managers lowered dividends after 1933, but the effect is imprecisely estimated in the specification without controls (Table 10, column 1). Adding the controls renders the effect significant at 5 percent. The point estimate indicates that the average firm with Jewish managers (which lost 22 percent of its managers) paid a dividend that was on average 0.34 percentage points lower from 1933 onward (Table 10, column 2). The average dividend paid by all firms in the sample was 4.6 percent, so the average firm with Jewish managers reduced its dividends by around 7.5 percent after 1933.

We also examine how the loss of Jewish managers affected firms' returns on assets, which is the ratio of profits before interest payments and taxes to total assets. The return on assets is a commonly used measure of the performance of firm managers, because it captures how efficiently the firm uses its available assets to generate profits (see Section 2.3 for details on the data). We estimate specifications equivalent to equation 4, using the return on assets measured in 1931, 1936, and 1940 as the dependent variable.

In the specification with firm and year fixed effects, the coefficient on the fraction of Jewish managers interacted with a post-1933 indicator is negative and significant at 5 percent (Table 10, column 3). In the specification with all controls, the coefficient remains significant at 5 percent. The point estimate implies that the return on assets of the average firm with Jewish managers was 4.1 percentage points lower after 1933 (Table 10, column 6). The results on dividends and returns on assets are robust in a sample of firms favored by the Nazis (Appendix Table A.18), to controlling for discrimination against firms perceived as "Jewish" (Appendix Table A.19), and to controlling for various demand shocks (Appendix Table A.20).

The evidence in this section indicates that the effect of losing Jewish managers went beyond stock prices. Firms became less profitable and less efficient after losing Jewish managers.

\section{Conclusion}

We study the effects of discrimination against Jewish managers on German firms. Our analysis relies on newly digitized data, based on a large number of historical sources. We assemble information on the characteristics of senior managers at all firms listed on the Berlin Stock Exchange in 1932, as well as stock prices, dividends, and returns on assets of these firms. We show that the removal of Jewish managers, caused by rising antisemitism after the Nazis came to power in 1933, negatively affected German firms, including some of the largest and most important corporations.

The findings of this paper suggest that individual managers are key to firm performance. We emphasize four aspects. First, firms were unable to adequately replace the characteristics of dismissed managers. As a result, affected firms had fewer managers who were important connectors to other firms, who had managerial experience, and who were university-educated. Second, the market valuation, profitability, and efficiency of affected firms fell. A back-of-the-envelope calcu- 
lation implies that removing the Jewish managers caused large reductions in the aggregate market valuation of German listed firms. Third, the effects persisted until at least ten years after managers started leaving their firms. This indicates that it takes a significant amount of time for firms to recover from losing managers. Fourth, we highlight particular managerial characteristics that are hard to replace. Losing managers with connections and university education, especially with graduate degrees in social sciences, had large effects on firm performance. Losing experienced managers was less harmful.

The findings also demonstrate that taste-based discrimination can cause firms to underperform. We thereby provide evidence in favor of Becker's (1957) influential theory. The magnitude of the estimates may not automatically generalize to other instances of discrimination because we study a severe form of discrimination against exceptional business leaders (List 2020). However, we estimate causal effects of discrimination, based on quasi-experimental variation. The causal interpretation of the results combined with Becker's (1957) theory suggest that the underlying theoretical mechanisms may apply more generally.

Firm performance may also suffer, for instance, when less drastic instances of discrimination lead to a loss of talent. The U.S. travel ban on citizens of seven Muslim-majority countries or the persecution of Turkish businessmen who follow the cleric Fethullah Gülen are recent examples of rising discrimination that are likely to affect firms. Even the perception of not being welcome in a country may lead to an outflow of qualified individuals with similar consequences. A survey in the wake of the Brexit referendum suggests, for example, that 12 percent of continental Europeans who make between $£ 100,001$ ( $\$ 130,000)$ and $£ 200,000$ a year were planning to leave the United Kingdom in the coming years (The Economist 2017a). The results in our paper indicate that such an exodus, and similar outflows of talented managers, could have large economic consequences. 


\section{References}

Abell, Peter, Teppo Felin, and Nicolai Foss, "Building Micro-Foundations for the Routines, Capabilities, and Performance Links," Managerial and Decision Economics, 2008, 29 (6), 489-502.

Acemoglu, Daron and Jörn-Steffen Pischke, "Why Do Firms Train? Theory and Evidence," Quarterly fournal of Economics, 1998, 113 (1), 79-119.

_ , Tarek A. Hassan, and James A. Robinson, "Social Structure and Development: A Legacy of the Holocaust in Russia," Quarterly fournal of Economics, 2011, 126 (2), 895-946.

Adams, Renée B. and Daniel Ferreira, "Women in the Boardroom and Their Impact on Governance and Performance," Journal of Financial Economics, 2009, 94 (2), 291-309.

Ahern, Kenneth R. and Amy K. Dittmar, "The Changing of the Boards: The Impact on Firm Valuation of Mandated Female Board Representation," Quarterly fournal of Economics, 2012, 127 (1), 137-197.

Akbulut-Yuksel, Mevlude and Mutlu Yuksel, "The Long-Term Direct and External Effects of Jewish Expulsions in Nazi Germany," American Economic Journal: Economic Policy, 2015, 7 (3), $58-85$.

Altonji, Joseph G. and Rebecca M. Blank, "Race and Gender in the Labor Market," in "Handbook of Labor Economics," Vol. 3, Elsevier, 1999, pp. 3143-3259.

Bajohr, Frank, "Aryanisation" in Hamburg: The Economic Exclusion of Jews and the Confiscation of Their Property in Nazi Germany, Berghahn, 2002.

Bandiera, Oriana, Renata Lemos, Andrea Prat, and Raffaella Sadun, "Managing the Family Firm: Evidence from CEOs at Work," Review of Financial Studies, 2017, 31 (5), 1605-1653.

_ , Stephen Hansen, Andrea Prat, and Raffaella Sadun, "CEO Behavior and Firm Performance," Journal of Political Economy, 2020, 128 (4), 1325-1369.

Banerjee, Abhijit, Arun G. Chandrasekhar, Esther Duflo, and Matthew O. Jackson, "The Diffusion of Microfinance," Science, July 2013, 341 (6144).

Barkai, Avraham, From Boycott to Annihilation: The Economic Struggle of German Jews, 1933-1943, Brandeis, 1990.

BBC, “Apple Shares Drop on Steve Jobs' Health," 2011. https://www.bbc.com/news/technology12218590.

_ , "Ugandan Asians Dominate Economy After Exile," 2016. https://www.bbc.co.uk/news/worldafrica-36132151.

Becker, Gary S., The Economics of Discrimination, University of Chicago Press, 1957.

_ , Human Capital: A Theoretical and Empirical Analysis, with Special Reference to Education, NBER, 1964.

Becker, Sascha O. and Hans K. Hvide, “Do Entrepreneurs Matter?” 2017.

- and Luigi Pascali, "Religion, Division of Labor, and Conflict: Anti-Semitism in Germany over 600 Years," American Economic Review, 2019, 109 (5), 1764-1804.

Bell, Alex, Raj Chetty, Xavier Jaravel, Neviana Petkova, and John Van Reenen, "Joseph Schumpeter Lecture, EEA Annual Congress 2017: Do Tax Cuts Produce more Einsteins? The Impacts of Financial Incentives Versus Exposure to Innovation on the Supply of Inventors," Fournal of the European Economic Association, 2019, 17 (3), 651-677.

Bell, Brian, Simone Pedemonte, and John Van Reenen, "CEO Pay and the Rise of Relative Performance Contracts: a Question of Governance?, 2018. CEP Discussion Paper 1439. 
Bender, Stefan, Nicholas Bloom, David Card, John Van Reenen, and Stefanie Wolter, "Management Practices, Workforce Selection, and Productivity, fournal of Labor Economics, 2018, 36 (S1), S371-S409.

Bennedsen, Morten, Francisco Pérez-González, and Daniel Wolfenzon, "Do CEOs Matter? Evidence from Hospitalization Events," Journal of Finance, forthcoming.

Benz, Wolfgang, Die fuden in Deutschland 1933-1945. Leben unter nationalsozialistischer Herrschaft, C.H. Beck, 1988.

Bertrand, M. and E. Duflo, "Field Experiments on Discrimination," in "Handbook of Field Experiments," Vol. 1, Elsevier, 2017, pp. 309-393.

Bertrand, Marianne, "New Perspectives on Gender," in "Handbook of Labor Economics," Vol. 4, Elsevier, 2011, pp. 1543-1590.

- and Antoinette Schoar, "Managing with Style: The Effect of Managers on Firm Policies," Quarterly fournal of Economics, 2003, 118 (4), 1169-1208.

Bianchi, Nicola and Michela Giorcelli, "Not All Management Training is Created Equal: Evidence from the Training Within Industry Program,” 2019.

Bloom, Nicholas and John Van Reenen, "Measuring and Explaining Management Practices Across Firms and Countries," Quarterly fournal of Economics, 2007, 122 (4), 1351-1408.

_ , Aprajit Mahajan, David McKenzie, and John Roberts, "Do Management Interventions Last? Evidence from India," American Economic Journal: Applied Economics, 2020, 12 (2), 198219.

_ , Benn Eifert, Aprajit Mahajan, David McKenzie, and John Roberts, "Does Management Matter? Evidence from India," Quarterly fournal of Economics, 2013, 128 (1), 1-51.

_ , Mark Schankerman, and John Van Reenen, "Identifying Technology Spillovers and Product Market Rivalry," Econometrica, 2013, 81 (4), 1347-1393.

_ , Raffaella Sadun, and John Van Reenen, "Management as a Technology?," 2017. NBER Working Paper 22327.

Bonacich, Phillip, "Power and Centrality: A Family of Measures," American fournal of Sociology, 1987, 92 (5), 1170-1182.

Borokhovich, Kenneth A., Kelly R. Brunarski, Maura S. Donahue, and Yvette S. Harman, "The Importance of Board Quality in the Event of a CEO Death," Financial Review, 2006, 41 (3), 307-337.

Botticini, Maristella and Zvi Eckstein, "From Farmers to Merchants, Conversions and Diaspora: Human Capital and Jewish History," Journal of the European Economic Association, 2007, 5 (5), 885-926.

_ and _, The Chosen Few: How Education Shaped Jewish History, 70-1492, Princeton University Press, 2012.

Brin, Sergey and Lawrence Page, "The Anatomy of a Large-Scale Hypertextual Web Search Engine," Computer Networks and ISDN Systems, 1998, 30 (1), 107-117.

Brooks, Wyatt, Kevin Donovan, and Terence R. Johnson, "Mentors or Teachers? Microenterprise Training in Kenya," American Economic Journal: Applied Economics, 2018, 10 (4), 196-221.

Bruer, Gerhardt, "Die Beteiligung der Juden an der deutschen Eisen- und Metallwirtschaft,” Der Morgen: Monatsschrift der Fuden in Deutschland, 1927, 3 (1), 86-98.

Bruhn, Miriam and Bilal Zia, "Stimulating Managerial Capital in Emerging Markets: The Impact of Business Training for Young Entrepreneurs," Journal of Development Effectiveness, 2013, 5 (2), $232-266$. 
_ , Dean Karlan, and Antoinette Schoar, "What Capital is Missing in Developing Countries?, American Economic Review, 2010, 100 (2), 629-33.

$\ldots, \ldots$, and _ , "The Impact of Consulting Services on Small and Medium Enterprises: Evidence from a Randomized Trial in Mexico," Journal of Political Economy, 2018, 126 (2), 635-687.

Cai, Jing and Adam Szeidl, "Interfirm Relationships and Business Performance," Quarterly fournal of Economics, 2018, 133 (3), 1229-1282.

Carroll, Berenice A, Design for Total War: Arms and Economics in the Third Reich, Mouton De Gruyter, 1968.

Chin, Aimee, "Long-run Labor Market Effects of Japanese American Internment During World War II on Working-age Male Internees," fournal of Labor Economics, 2005, 23 (3), 491-525.

Coff, Russell and David Kryscynski, "Drilling for Micro-Foundations of Human Capital-Based competitive Advantages," Academy of Management fournal, 2011, 53, 1090-1109.

Cole, Shawn, Thomas Sampson, and Bilal Zia, "Prices or Knowledge? What Drives Demand for Financial Services in Emerging Markets?”, fournal of Finance, 2011, 66 (6), 1933-1967.

Cox, Josie, "Nike CEO Slams Donald Trump's 'Muslim Ban' Voicing Concern for Athletes like Sir Mo Farah," The Independent, 2017. https://www.independent.co.uk/news/business/news/nikeceo-donald-trump-muslim-ban-immigration-mark-parker-athletes-mo-farah-refugees-sportsretailer-a7553436.html.

D’Acunto, Francesco, Marcel Prokopczuk, and Michael Weber, "Historical Antisemitism, Ethnic Specialization, and Financial Development," Review of Economic Studies, 2019, 86(3), 11701206.

Denis, David J. and Diane K. Denis, "Performance Changes Following Top Management Dismissals," Journal of Finance, 1995, 50 (4), 1029-1057.

Dessein, Wouter and Andrea Prat, "Organizational Capital, Corporate Leadership, and Firm Dynamics," 2019.

Drexler, Alejandro, Greg Fischer, and Antoinette Schoar, "Keeping It Simple: Financial Literacy and Rules of Thumb," American Economic Journal: Applied Economics, 2014, 6 (2), 1-31.

Eckbo, B. Espen, Knut Nygaard, and Karin S. Thorburn, "Does Gender-Balancing the Board Reduce Firm Value?," 2016.

Ekkehard, Erich, Sigilla Veri: Ein Lexikon zur Judenfrage in 9 Baenden, U. Bodung, 1929.

Elon, A., The Pity of It All: A Portrait of German Jews, 1743-1933, Allen Lane, 2003.

Enderis, Guido, “Germany Rejoices Over Gains of Year," New York Times, 1933. January 1, 1933.

Fama, Eugene F. and Kenneth R. French, "The Cross-section of Expected Stock Returns," fournal of Finance, 1992, 47 (2), 427-465.

Farrell, Kathleen A. and Philip L. Hersch, "Additions to Corporate Boards: The Effect of Gender," Journal of Corporate Finance, 2005, 11 (1-2), 85-106.

Fee, C. Edward, Charles J. Hadlock, and Joshua R. Pierce, "Managers With and Without Style: Evidence using Exogenous Variation," Review of Financial Studies, 2013, 26 (3), 567-601.

Ferguson, Thomas and Hans-Joachim Voth, "Betting on Hitler - The Value of Political Connections in Nazi Germany," Quarterly fournal of Economics, 2008, 123 (1), 101-137.

Fich, Eliezer M. and Anil Shivdasani, “Are Busy Boards Effective Monitors?”, fournal of Finance, 2006, 61 (2), 689-724.

Flabbi, Luca, Mario Macis, Andrea Moro, and Fabiano Schivardi, "Do Female Executives Make a Difference? The Impact of Female Leadership on Gender Gaps and Firm Performance," Economic Journal, 2019, 129 (622), 2390-2423. 
G., Jr. Fryer Roland, "Management and Student Achievement: Evidence from a Randomized Field Experiment," 2017. NBER Working Paper 23437.

Giorcelli, Michela, "The Long-Term Effects of Management and Technology Transfers," American Economic Review, 2019, 109 (1), 121-152.

Glaeser, Edward L., David Laibson, and Bruce Sacerdote, "An Economic Approach to Social Capital," Economic fournal, 2002, 112 (483), F437-F458.

Gömmel, Rainer and Hans Pohl, Deutsche Börsengeschichte, Knapp, 1992.

Gosnell, Greer K., John A. List, and Robert D. Metcalfe, "The impact of Management Practices on Employee Productivity: A Field Experiment With Airline Captains," Fournal of Political Economy, 2020, 128 (4), 1195-1233.

Greenstone, Michael, Richard Hornbeck, and Enrico Moretti, "Identifying Agglomeration Spillovers: Evidence from Winners and Losers of Large Plant Openings," fournal of Political Economy, 2010, 118 (3), 536-598.

Grosfeld, Irena, Alexander Rodnyansky, and Ekaterina Zhuravskaya, "Persistent Antimarket Culture: A Legacy of the Pale of Settlement after the Holocaust," American Economic Fournal. Economic Policy, 2013, 5 (3), 189.

Hansen, Ernst Willi, Reichswehr und Industrie, Vol. 24 of Wehrwissenschaftliche Forschungen, Harald Boldt Verlag, 1978. Boppard am Rhein.

Haselmann, Rainer, David Schoenherr, and Vikrant Vig, "Rent Seeking in Elite Networks," Journal of Political Economy, March 2018, 126 (4), 1638-1690.

Hayes, Rachel M. and Scott Schaefer, "How Much Are Differences in Managerial Ability Worth?, Journal of Accounting and Economics, 1999, 27 (2), 125-148.

Hellerstein, Judith K., David Neumark, and Kenneth R. Troske, "Market Forces and Sex Discrimination," Journal of Human Resources, 2002, pp. 353-380.

Hoffman, Mitchell and Steven Tadelis, "People Management Skills, Employee Attrition, and Manager Rewards: An Empirical Analysis," 2018.

Hornung, Erik, "Immigration and the Diffusion of Technology: The Huguenot Diaspora in Prussia," American Economic Review, 2014, 104 (1), 84-122.

Hsieh, Chang-Tai, Erik Hurst, Charles I. Jones, and Peter J. Klenow, "The Allocation of Talent and U.S. Economic Growth," Econometrica, 2019, 87 (5), 1439-1474.

Huber, Kilian, "Disentangling the Effects of a Banking Crisis: Evidence from German Firms and Counties," American Economic Review, 2018, 103 (3), 868-898.

Iacovone, Leonardo, William F. Maloney, and David J. Mckenzie, Improving Management with Individual and Group-Based Consulting: Results from a Randomized Experiment in Colombia 2019. World Bank Working Paper 8854.

Ihlow, Jens and Jens Carsten Jackwerth, "Stock Market Performance of Jewish Firms During the Third Reich," 2020.

Jackson, Matthew O., Social and Economic Networks, Princeton University Press, 2010.

James, Harold, Die Deutsche Bank und die "Arisierung", C.H. Beck, 2001.

Jenter, Dirk and Katharina A. Lewellen, "Performance-induced CEO Turnover," 2017.

_ , Egor Matveyev, and Lukas Roth, "Good and Bad CEOs," 2017.

Johnson, W. Bruce, Robert P. Magee, Nandu J. Nagarajan, and Harry A. Newman, “An Analysis of the Stock Price Reaction to Sudden Executive Deaths: Implications for the Managerial Labor Market," Journal of Accounting and Economics, 1985, 7 (1-3), 151-174.

Kaplan, Steven N., Mark M. Klebanov, and Morten Sorensen, "Which CEO Characteristics and Abilities Matter?," Journal of Finance, 2012, 67 (3), 973-1007. 
Karlan, Dean and Martin Valdivia, "Teaching Entrepreneurship: Impact of Business Training on Microfinance Clients and Institutions," Review of Economics and Statistics, 2011, 93 (2), 510-527.

_ , Ryan Knight, and Christopher Udry, "Consulting and Capital Experiments with Microenterprise Tailors in Ghana," Journal of Economic Behavior \& Organization, 2015, 118, 281-302.

Katz, Leo, “A New Status Index Derived from Sociometric Analysis," Psychometrika, 1953, 18 (1), 39-43.

Kawaguchi, Daiji, “A Market Test for Sex Discrimination: Evidence from Japanese Firm-level Panel Data," International Journal of Industrial Organization, 2007, 25 (3), 441-460.

Köhler, Ingo, Die "Arisierung" der Privatbanken im Dritten Reich, C.H. Beck, 2008.

Koning, Juliette, "Chineseness and Chinese Indonesian Business Practices: A Generational and Discursive Enquiry," East Asia, 2007, 24 (2), 129-152.

Koudijs, Peter and Hans-Joachim Voth, "Individual Skill and Market Liquidity: Evidence from the Removal of Jewish Market Makers in WWII," 2020.

Kramarz, Francis and David Thesmar, "Social Networks in the Boardroom," Fournal of the European Economic Association, 2013, 11 (4), 780-807.

Kreutzmüller, Christoph, Final Sale in Berlin: The Destruction of Jewish Commercial Activity, 1930-1945, Berghahn, 2017.

Landsberg, Ernst, "Die Beteiligung der Juden an deutschen Montanunternehmungen: Unterschiede der Besitzstruktur nach Landschaften und Material," Der Morgen: Monatsschrift der fuden in Deutschland, 1927, 3 (2), 201-215.

_ , "Die Juden in der Textilindustrie," Der Morgen: Monatsschrift der Juden in Deutschland, 1927, 3 (1), 99-113.

Lazear, Edward P., Kathryn L Shaw, and Christopher T. Stanton, "The Value of Bosses," Fournal of Labor Economics, 2015, 33 (4), 823-861.

List, John A., "The Nature and Extent of Discrimination in the Marketplace: Evidence from the Field," Quarterly fournal of Economics, 2004, 119 (1), 49-89.

_ , "Non Est Disputandum De Generalizability? A Glimpse Into the External Validity Trial," 2020.

- and Imran Rasul, "Field Experiments in Labor Economics," in "Handbook of Labor Economics," Vol. 4, Elsevier, 2011, pp. 103-228.

Lowenthal, Ernst G., Fuden in Preussen: biographisches Verzeichnis, ein repräsentativer Querschnitt, Reimer, 1981.

Lucas, Robert E., "On the Size Distribution of Business Firms," Bell Fournal of Economics, 1978, pp. 508-523.

Malmendier, Ulrike and Geoffrey Tate, "CEO Overconfidence and Corporate Investment," fournal of Finance, 2005, 60 (6), 2661-2700.

Matsa, David A. and Amalia R. Miller, "A Female Style in Corporate Leadership? Evidence from Quotas," American Economic Journal: Applied Economics, 2013, 5 (3), 136-69.

McGregor, Jena, "Deeply Concerned: Corporate America Responds to Trump's Travel Ban," Washington Post, $2017 . \quad$ https://www.washingtonpost.com/news/onleadership/wp/2017/01/30/deeply-concerned-corporate-america-responds-to-trumps-travelban.

Moretti, Enrico, "Local Multipliers," American Economic Review, 2010, 100 (2), 1-7.

Mosse, Werner E., Jews in the German Economy: The German-fewish Economic Elite 1820-1935, Claredon Press, 1987.

Münzel, Martin, Die jüdischen Mitglieder der deutschen Wirtschaftselite 1927-1955: VerdrängungEmigration-Rückkehr, Ferdinand Schönborn, 2006. 
Murphy, Kevin J. and Jerold L. Zimmerman, "Financial Performance Surrounding CEO Turnover," fournal of Accounting and Economics, 1993, 16 (1-3), 273-315.

Nguyen, Bang Dang and Kasper Meisner Nielsen, "The Value of Independent Directors: Evidence from Sudden Deaths," Journal of Financial Economics, 2010, 98 (3), 550-567.

Nygaard, Knut, "Forced Board Changes: Evidence from Norway," 2011. Norwegian School of Economics and Business Administration Discussion Paper SAM 5/2011.

Pástor, Luboš and Pietro Veronesi, "Stock Valuation and Learning about Profitability," fournal of Finance, 2003, 58 (5), 1749-1789.

Post, Corinne and Kris Byron, "Women on Boards and Firm Financial Performance: A Metaanalysis," Academy of Management fournal, 2015, 58 (5), 1546-1571.

Priester, Hans, "Die Teilnahme der deutschen Juden am Geldmarkt," Der Morgen: Monatsschrift der Juden in Deutschland, 1927, 3 (3), 323-330.

Räth, Norbert, "Rezessionen in historischer Betrachtung," Statistisches Bundesamt: Wirtschaft und Statistik, 2009.

Reuters, "European Shares Extend Losing Streak as Autos, Ryanair Drop," 2018. https://uk.reuters.com/article/us-europe-stocks/european-shares-extend-losing-streak-asautos-ryanair-drop-idUKKBN1KD21M.

Ritschl, Albrecht, "Fiscal Destruction: Confiscatory Taxation of Jewish Property and Income in Nazi Germany," in Christoph Kreutzmueller and Jonathan Zatlin, eds., Dispossession: Plundering German Jewry, 1933-1945, Michigan University Press, 2020.

Röder, W. and H.A. Strauss, eds, Biographisches Handbuch der deutschsprachigen Emigration nach 1933: Band I Politik, Wirtschaft, Öffentliches Leben, K.G. Saur, 1980.

Ronge, Ulrich, Die langfristige Rendite deutscher Standardaktien: Konstruktion eines historischen Aktienindex ab Ultimo 1870 bis Ultimo 1959, Lang, 2002.

Salas, Jesus M., "Entrenchment, Governance, and the Stock Price Reaction to Sudden Executive Deaths," Journal of Banking \& Finance, 2010, 34 (3), 656-666.

Schmid, Stefan, Frederic Altfeld, and Tobias Dauth, "Der Doktortitel unter Vorstands- und Aufsichtsratsmitgliedern der DAX-30-Unternehmen. Immer noch weit verbreitet und von hoher Bedeutung?," Zeitschrift für Corporate Governance, 2017, 12 (4), 152-158.

Scoville, Warren C., "The Huguenots in the French Economy, 1650-1750," Quarterly fournal of Economics, 1953, 67 (3), 423-444.

Shleifer, Andrei and Robert W. Vishny, "Management Entrenchment: The Case of Managerspecific Investments," Journal of Financial Economics, 1989, 25 (1), 123-139.

Smith, Matthew, Danny Yagan, Owen Zidar, and Eric Zwick, "Capitalists in the Twenty-First Century," Quarterly Journal of Economics, 2019, 134 (4), 1675-1745.

Solheim, Jostein, "Why Trump's Travel Ban Is Bad For Business," Huffington Post, 2017. https://www.huffingtonpost.com/author/jostein-solheim.

Strauss, Herbert A., "Jews in German History: Persecution, Emigration, Acculturation," in Werner Röder and Herbert A. Strauss, eds., International Biographical Dictionary of Central European Émigrés, K.G. Saur, 1999.

Szymanski, Stefan, "A Market Test for Discrimination in the English Professional Soccer Leagues," Journal of Political Economy, 2000, 108 (3), 590-603.

Tetzlaff, Walter, "Kurzbiographien bedeutender deutscher Juden des 20. Jahrhunderts," Lindhorst, 1982, p. 134. 
The Economist, "Brexit Is Giving High-flying Foreigners Itchy Feet," 2017. https://www.economist.com/britain/2017/10/26/brexit-is-giving-high-flying-foreigners-itchyfeet.

- "Turkey's Purges Are Hitting Its Business Class," 2017. https://www.economist.com/europe/2017/02/02/turkeys-purges-are-hitting-its-business-class.

Tooze, Adam, The Wages of Destruction: The Making and Breaking of the Nazi Economy, Penguin, 2008.

United States Holocaust Memorial Museum, “German Jews During the Holocaust, 1939-1945," 2017.

U.S. CWRIC, "Personal Justice Denied: Report of the Commission on Wartime Relocation and Internment of Civilians," 1982. https://www.archives.gov/research/japanese-americans/justicedenied.

Waldinger, Fabian, "Quality Matters: the Expulsion of Professors and the Consequences for PhD Student Outcomes in Nazi Germany," Journal of Political Economy, 2010, 118 (4), 787-831.

_ , "Peer Effects in Science: Evidence from the Dismissal of Scientists in Nazi Germany," Review of Economic Studies, 2012, 79 (2), 838-861.

- , "Bombs, Brains, and Science: The Role of Human and Physical Capital for the Creation of Scientific Knowledge," Review of Economics and Statistics, 2016, 98 (5), 811-831.

Walk, Joseph, Kurzbiographien zur Geschichte der fuden: 1918-1945, Walter de Gruyter, 2014.

Weber, Andrea and Christine Zulehner, "Competition and Gender Prejudice: Are Discriminatory Employers Doomed to Fail?,” Journal of the European Economic Association, 2014, 12 (2), 492-521.

Wenzel, Georg, Deutscher Wirtschaftsführer: Lebensgänge deutscher Wirtschaftspersönlichkeiten: ein Nachschlagebuch über 13000 Wirtschaftspersönlichkeiten unserer Zeit 1929.

Windolf, Paul, Die Expansion der Universitäten 1870-1985. Ein internationaler Vergleich., Enke, 1990.

_, "The German-Jewish Economic Elite (1900 to 1930)," Zeitschrift für Unternehmensgeschichte, 2011, $56(2), 135-162$.

Wingfield, Nick and Daisuke Wakabayashi, "Tech Companies Fight Trump Immigration Order in Court," New York Times, 2017. https://nyti.ms/2jPCoNp.

Wolfers, Justin, "Diagnosing Discrimination: Stock Returns and CEO Gender,” fournal of the European Economic Association, 2006, 4 (2-3), 531-541.

Worrell, Dan L., Wallace N. Davidson, P.R. Chandy, and Sharon L. Garrison, "Management Turnover Through Deaths of Key Executives: Effects on Investor Wealth," Academy of Management fournal, 1986, 29 (4), 674-694.

Ziegler, Dieter, “Die Feudalisierung des wirtschaftlichen Großbürgertums seit 1848," in Peter Lundgreen, ed., Sozial- und Kulturgeschichte des Bürgertums: Eine Bilanz des Bielefelder Sonderforschungsbereichs (1986-1997), Vol. 18, Vandenhoeck \& Ruprecht, 2000.

_ , Grossbürger und Unternehmer: Die deutsche Wirtschaftselite im 20. Jahrhundert, Vandenhoeck \& Ruprecht, 2000. 


\section{Figures}

Figure 1: Percentage of Jewish Managers over Time

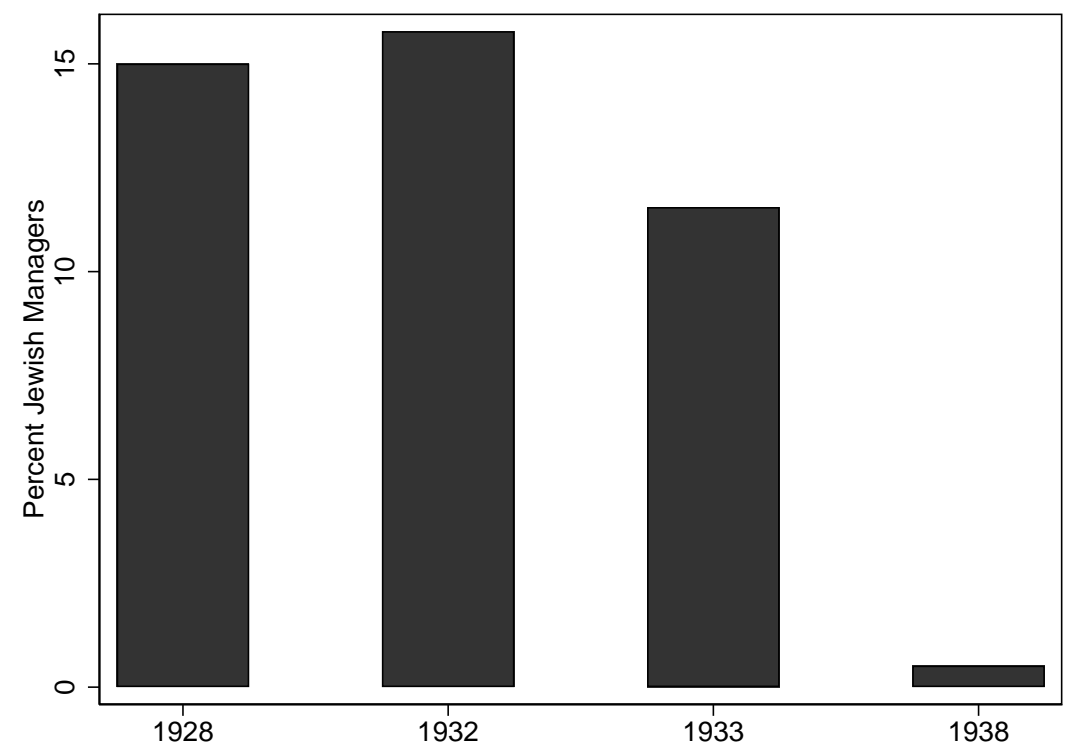

Notes: The figure reports the percentage of senior management positions that were held by Jewish managers in the 655 firms that were listed on the Berlin Stock Exchange in 1932. 
Figure 2: The Effect on the Characteristics of Firms' Senior Management

(a) Managers With Tenure Since 1928

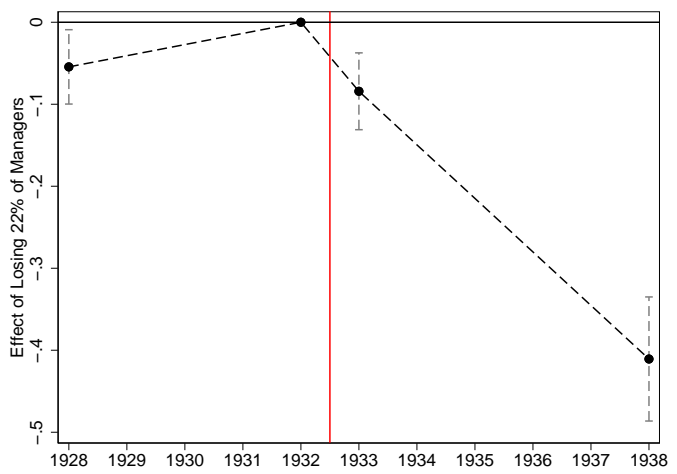

(c) Managers With University Education

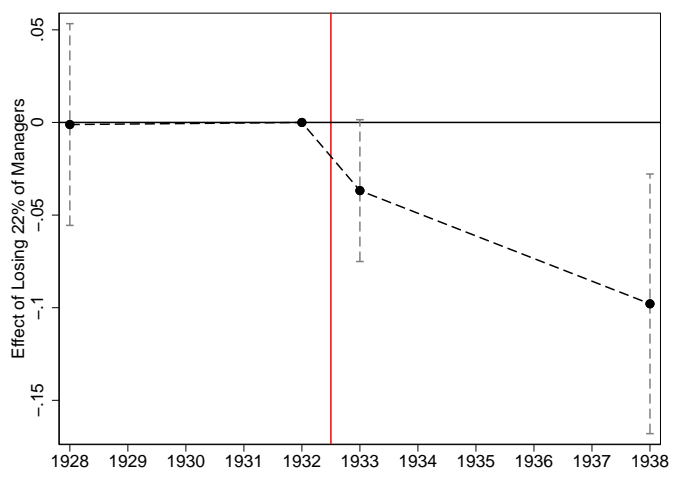

(b) Managers With Experience Since 1928

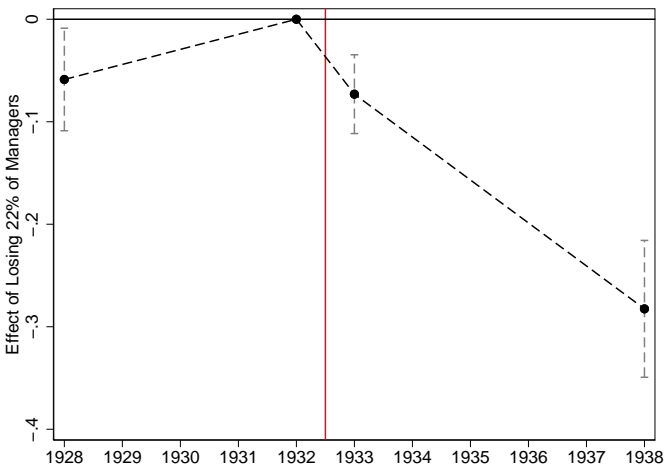

(d) Connections

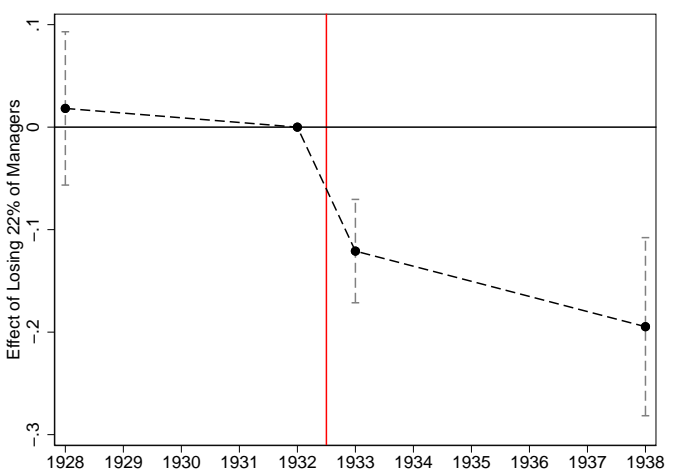

Notes: The figure reports yearly coefficients $\left(\beta_{\tau}\right)$ and 95 percent confidence intervals from equation 1 . Each panel reports results for a different dependent variable, as indicated in the heading of the panel. The dependent variables are in natural logarithms. The main explanatory variables are the fraction of Jewish managers in 1932, interacted with a fixed effect for each year. The interaction with 1932, the last year before the Nazis gained power, is the excluded interaction. Coefficients and standard errors are scaled to reflect the effect on the average firm with Jewish managers in 1932. The average such firm lost 22 percent of its managers after 1932. All regressions include firm and year fixed effects. Standard errors are clustered at the firm level. 


\section{Figure 3: The Effect on Stock Prices}

(a) With Firm and Year Fixed Effects

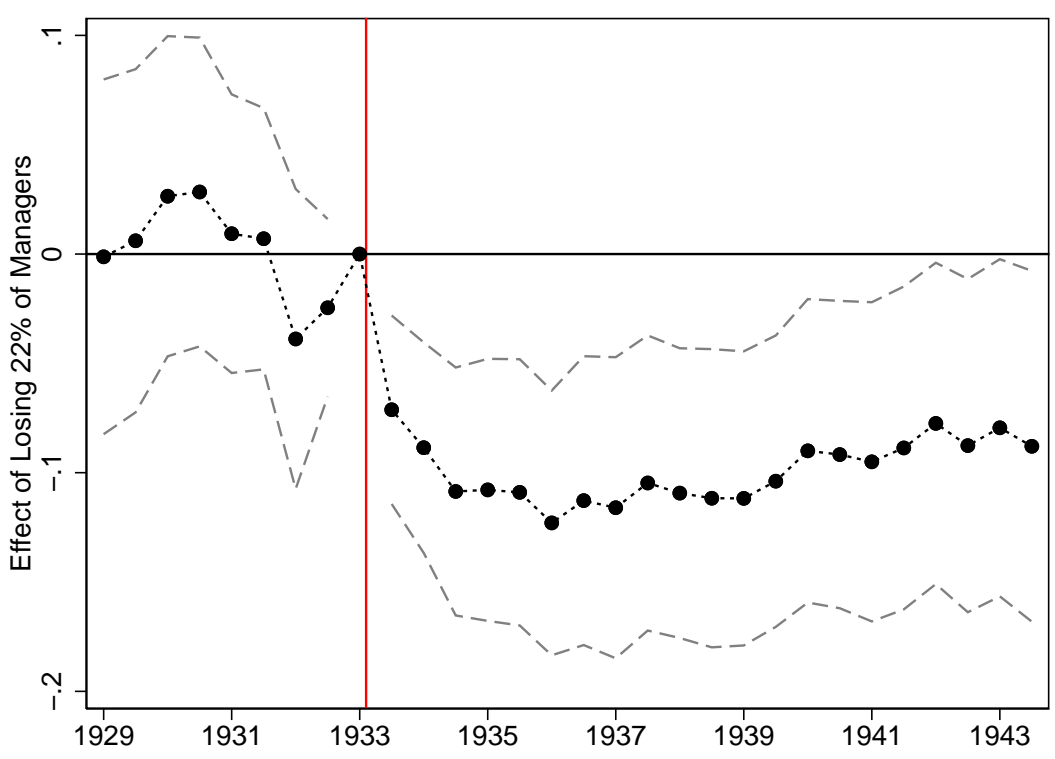

(b) With All Controls

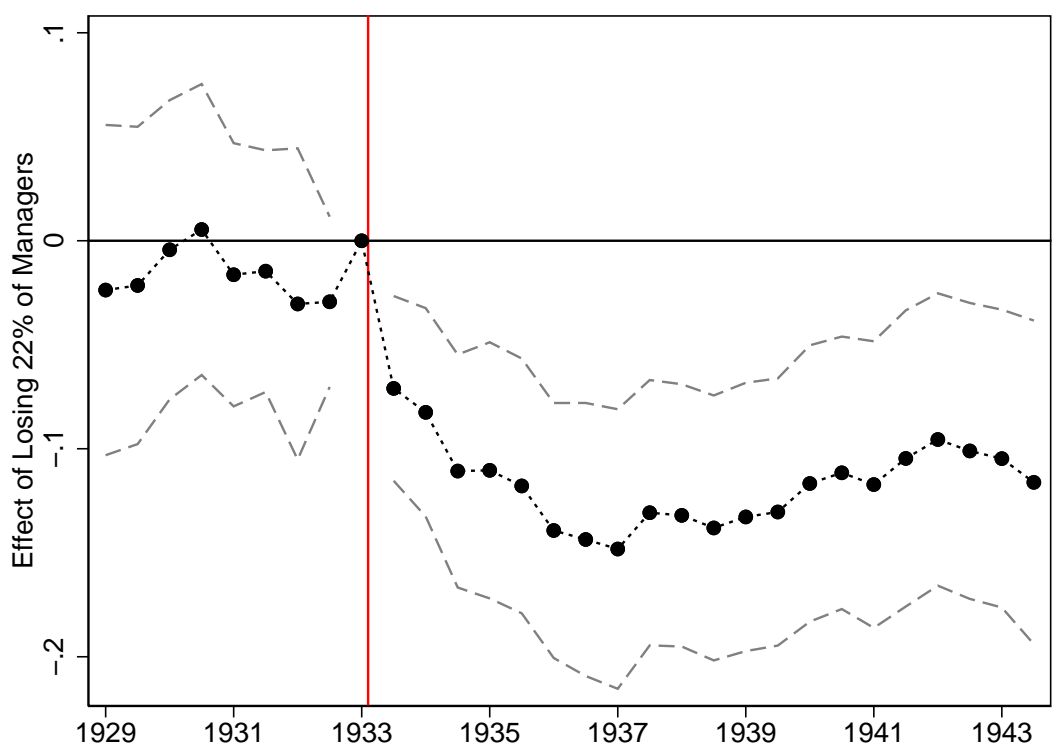

Notes: The figure reports coefficients $\left(\beta_{\tau}\right)$ and 95 percent confidence intervals from equation 3 . The dependent variable is the natural logarithm of the stock price. Stock prices are averaged in a plus-minus 10-day window around January 10th and July 10th of each year. The main explanatory variables are the fraction of Jewish managers in 1932, interacted with a fixed effect for each time period. The interaction with January 1933, the last period before the Nazis gained power, is the excluded interaction. Coefficients and standard errors are scaled to reflect the effect on the average firm with Jewish managers in 1932. The average such firm lost 22 percent of its managers after 1932. Panel (a) controls for firm and time fixed effects. Panel (b) additionally controls for an indicator for any connections to the Nazi Party, an indicator for whether the firm published its 1932 financial statement in January, firm age in 1932, firm nominal capital in 1932, and industry fixed effects. All these additional controls are interacted with a full set of time fixed effects. Standard errors are clustered at the firm level. 


\section{Tables}

\section{Table 1: Summary Statistics ON MANAgERs IN 1932}

\begin{tabular}{|c|c|c|c|c|}
\hline & (1) & (2) & (3) & (4) \\
\hline & $\begin{array}{c}\text { All } \\
\text { Managers }\end{array}$ & $\begin{array}{c}\text { Jewish } \\
\text { Managers }\end{array}$ & $\begin{array}{c}\text { Non-Jewish } \\
\text { Managers }\end{array}$ & $\begin{array}{c}\text { Non-Jewish Managers } \\
\text { in Firms with } \\
\text { Jewish Managers }\end{array}$ \\
\hline Number of senior management positions & 7,791 & 1,230 & 6,561 & 5,073 \\
\hline Number of senior managers & 4,873 & 423 & 4,450 & 3,077 \\
\hline \multicolumn{5}{|l|}{ Manager characteristics (manager level): } \\
\hline$\%$ managers with university education & 36.18 & 45.15 & 35.33 & 38.22 \\
\hline$\%$ managers with graduate education & 24.24 & 35.93 & 23.12 & 24.63 \\
\hline$\%$ managers with Kommerzienrat title & 4.72 & 8.75 & 4.34 & 4.91 \\
\hline \% managers with tenure since 1928 & 62.54 & 70.57 & 61.78 & 61.25 \\
\hline$\%$ managers with experience since 1928 & 69.61 & 82.98 & 68.34 & 69.61 \\
\hline $\begin{array}{l}\text { Avg. number of board positions in other firms } \\
\text { (= average number of firms connected to) }\end{array}$ & 2.22 & 5.02 & 1.96 & 2.42 \\
\hline
\end{tabular}




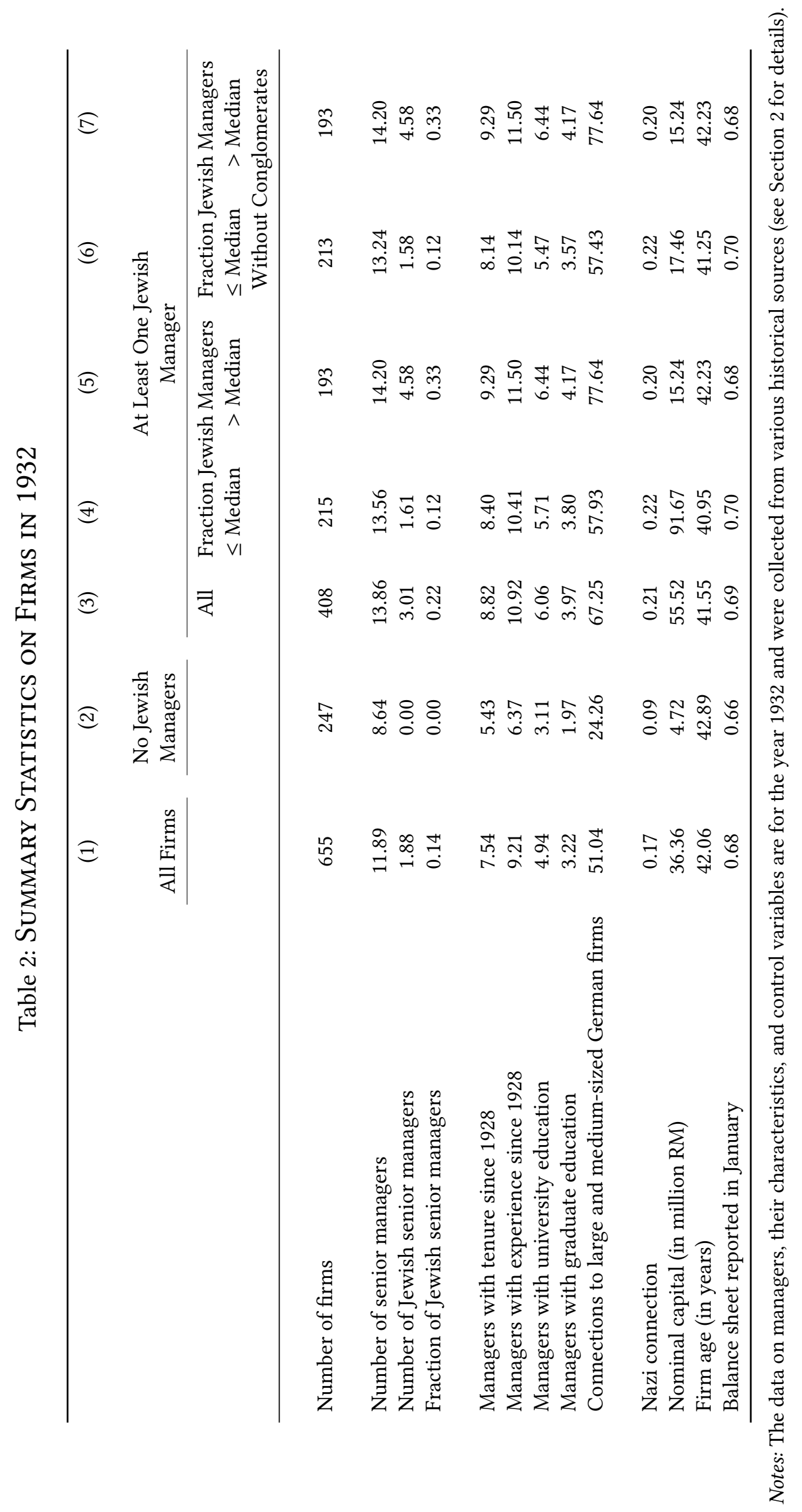


Table 3: The Effect on the Characteristics of Firms' Senior Management
(1)
$(2)$
(3)
$(4)$
(5)
(6)

Panel A: Dep. Variable: $\log (\#$ of Managers with Tenure since 1928), \# of obs./firms: 2412/655

\begin{tabular}{lcccccc}
\hline & & & & & & \\
Frac. Jewish Managers (1932) & $-0.847^{* * *}$ & $-0.842^{* * *}$ & $-0.837^{* * *}$ & $-0.837^{* * *}$ & $-0.836^{* * *}$ & $-0.824^{* * *}$ \\
$\times$ Post 1933 & $(0.110)$ & $(0.112)$ & $(0.112)$ & $(0.112)$ & $(0.112)$ & $(0.113)$ \\
$\mathrm{R}^{2}$ & 0.748 & 0.748 & 0.749 & 0.749 & 0.749 & 0.756 \\
\hline
\end{tabular}

Panel B: Dep. Variable: $\log$ (\# of Managers with Experience since 1928), \# of obs./firms: 2493/655

\begin{tabular}{lcccccc} 
Frac. Jewish Managers (1932) & $-0.601^{* * *}$ & $-0.617^{* * *}$ & $-0.615^{* * *}$ & $-0.613^{* * *}$ & $-0.609^{* * *}$ & $-0.616^{* * *}$ \\
$\times$ Post 1933 & $(0.104)$ & $(0.104)$ & $(0.104)$ & $(0.105)$ & $(0.105)$ & $(0.107)$ \\
$\mathrm{R}^{2}$ & 0.658 & 0.661 & 0.662 & 0.664 & 0.664 & 0.679 \\
\hline
\end{tabular}

Panel C: Dep. Variable: $\log$ (\# of Managers with University Education), \# of obs./firms: 2408/645

\begin{tabular}{lcccccc} 
Frac. Jewish Managers (1932) & $-0.292^{* * *}$ & $-0.278^{* *}$ & $-0.279^{* *}$ & $-0.277^{* *}$ & $-0.276^{* *}$ & $-0.238^{* *}$ \\
$\times$ Post 1933 & $(0.109)$ & $(0.108)$ & $(0.109)$ & $(0.109)$ & $(0.109)$ & $(0.109)$ \\
$\mathrm{R}^{2}$ & 0.018 & 0.022 & 0.024 & 0.030 & 0.031 & 0.054 \\
\hline
\end{tabular}

Panel D: Dep. Variable: $\log$ (\# of Connections), \# of obs./firms: 2510/655

\begin{tabular}{lcccccc}
\hline Frac. Jewish Managers (1932) & $-0.744^{* * *}$ & $-0.756^{* * *}$ & $-0.759^{* * *}$ & $-0.755^{* * *}$ & $-0.755^{* * *}$ & $-0.712^{* * *}$ \\
$\times$ Post 1933 & $(0.142)$ & $(0.143)$ & $(0.143)$ & $(0.144)$ & $(0.144)$ & $(0.145)$ \\
$\mathrm{R}^{2}$ & 0.256 & 0.258 & 0.261 & 0.263 & 0.263 & 0.283 \\
\hline & & & & & & \\
Firm FE & Yes & Yes & Yes & Yes & Yes & Yes \\
Time FE & Yes & Yes & Yes & Yes & Yes & Yes \\
Nazi Connection $\times$ Time FE & & Yes & Yes & Yes & Yes & Yes \\
Reporting Period $\times$ Time FE & & & Yes & Yes & Yes & Yes \\
Firm Age $\times$ Time FE & & & & Yes & Yes & Yes \\
Nominal Capital $\times$ Time FE & & & & & Yes & Yes \\
Industry FE $\times$ Time FE & & & & & & Yes \\
\hline
\end{tabular}

Notes: The Table reports point estimates $\left(\beta_{1}\right)$ from equation 2 for different dependent variables, which are indicated in the heading of each panel. The main explanatory variable measures the fraction of Jewish managers in 1932, interacted with an indicator for the years after 1932. The control variables include: an indicator for any connections to the Nazi Party, an indicator for whether the firm published its 1932 financial statement in January, firm age in 1932, firm nominal capital in 1932, and industry fixed effects. All controls are interacted with a full set of year fixed effects. The data include the years $1928,1932,1933$, and 1938. Standard errors are clustered at the firm level. Significance levels: $* * * \mathrm{p}<0.01, * * \mathrm{p}<0.05$, and $*$ $\mathrm{p}<0.1$. 
Table 4: The Effect on Stock Prices

\begin{tabular}{lcccccc}
\hline & $(1)$ & $(2)$ & $(3)$ & $(4)$ & $(5)$ & $(6)$ \\
Dep. Variable: $\log$ (Stock Price) & & & & & & \\
\hline Frac. Jewish Managers (1932) & $-0.469^{* * *}$ & $-0.459^{* * *}$ & $-0.458^{* * *}$ & $-0.479^{* * *}$ & $-0.479^{* * *}$ & $-0.464^{* * *}$ \\
$\times$ Post 1933 & $(0.138)$ & $(0.136)$ & $(0.136)$ & $(0.134)$ & $(0.134)$ & $(0.138)$ \\
& & & & & & \\
Firm FE & Yes & Yes & Yes & Yes & Yes & Yes \\
Time FE & Yes & Yes & Yes & Yes & Yes & Yes \\
Nazi Connection $\times$ Time FE & & Yes & Yes & Yes & Yes & Yes \\
Reporting Period $\times$ Time FE & & & Yes & Yes & Yes & Yes \\
Firm Age $\times$ Time FE & & & & Yes & Yes & Yes \\
Nominal Capital $\times$ Time FE & & & & & Yes & Yes \\
Industry FE $\times$ Time FE & & & & & & Yes \\
& & & & & & \\
Number of Observations & 12710 & 12710 & 12710 & 12710 & 12710 & 12710 \\
Number of Firms & 655 & 655 & 655 & 655 & 655 & 655 \\
$\mathrm{R}^{2}$ & 0.566 & 0.569 & 0.570 & 0.580 & 0.582 & 0.622 \\
\hline
\end{tabular}

Notes: The dependent variable is the natural logarithm of the stock price. Stock prices are averaged in a plus-minus 10-day window around January 10th and July 10th of each year. The main explanatory variable measures the fraction of Jewish managers in 1932, interacted with an indicator for the months after January 1933. The control variables include: an indicator for any connections to the Nazi Party, an indicator for whether the firm published its 1932 financial statement in January, firm age in 1932, firm nominal capital in 1932, and industry fixed effects. All controls are interacted with a full set of time fixed effects. The data include the months January and July for the years from 1929 to 1943 . Standard errors are clustered at the firm level. Significance levels: $* * * \mathrm{p}<0.01, * * \mathrm{p}<0.05$, and $* \mathrm{p}<0.1$. 


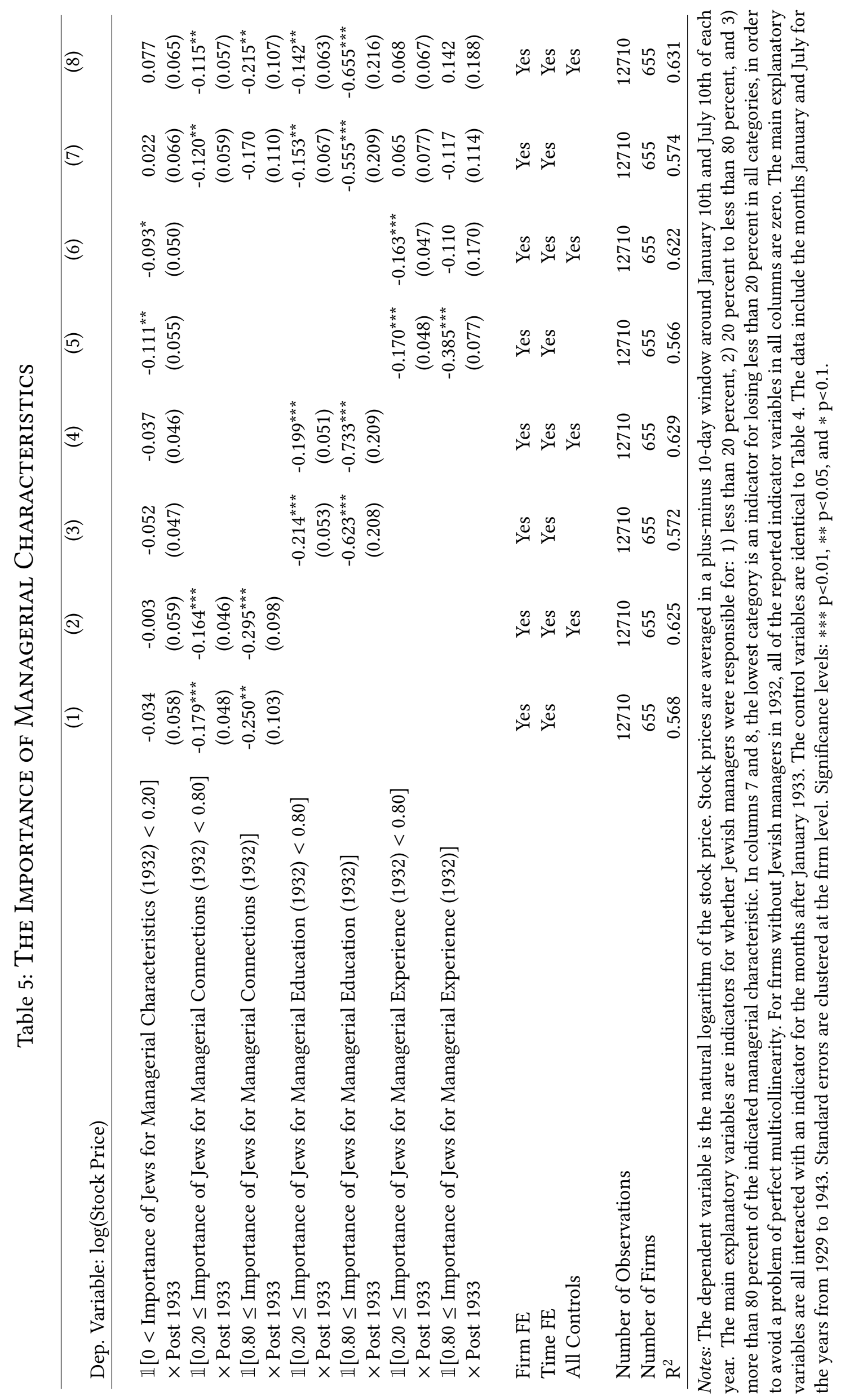


Table 6: Graduate Vs. Basic University Education And STEM Vs. Social Science GRADUATE EDUCATION

\begin{tabular}{|c|c|c|c|c|}
\hline \multirow[b]{2}{*}{ Dep. Variable: $\log$ (Stock Price) } & (1) & $(2)$ & \multicolumn{2}{|c|}{ Firms in $\quad(4)$} \\
\hline & Full Sample & Full Sample & $\begin{array}{r}\mathrm{F} \\
\text { STEM Industries }\end{array}$ & $\begin{array}{l}\text { irms in } \\
\text { Non-STEM Industries }\end{array}$ \\
\hline $\mathbb{1}[0<$ Importance of Jews for Managerial Characteristics $(1932)<0.20]$ & 0.005 & 0.009 & 0.032 & 0.029 \\
\hline$\times$ Post 1933 & $(0.046)$ & $(0.047)$ & $(0.083)$ & $(0.063)$ \\
\hline $\mathbb{1}[0.20 \leq$ Importance of Jews for Managers with Basic University Education $(1932)<0.80]$ & -0.053 & -0.051 & -0.034 & -0.034 \\
\hline$\times$ Post 1933 & $(0.071)$ & $(0.072)$ & $(0.151)$ & $(0.069)$ \\
\hline $\mathbb{1}[0.80 \leq$ Importance of Jews for Managers with Basic University Education (1932)] & 0.062 & 0.053 & 0.083 & -0.007 \\
\hline$\times$ Post 1933 & $(0.122)$ & $(0.122)$ & $(0.113)$ & $(0.199)$ \\
\hline $\mathbb{1}[0.20 \leq$ Importance of Jews for Managers with Graduate Education $(1932)<0.80]$ & $-0.190^{* * *}$ & & & \\
\hline$\times$ Post 1933 & $(0.052)$ & & & \\
\hline $\mathbb{1}[0.80 \leq$ Importance of Jews for Managers with Graduate Education (1932)] & $-0.350^{* * *}$ & & & \\
\hline$\times$ Post 1933 & $(0.114)$ & & & \\
\hline $\mathbb{1}[0.20 \leq$ Importance of Jews for STEM Graduate Education $(1932)<0.80]$ & & -0.004 & -0.057 & 0.037 \\
\hline$\times$ Post 1933 & & $(0.076)$ & $(0.089)$ & $(0.107)$ \\
\hline $\mathbb{1}[0.80 \leq$ Importance of Jews for STEM Graduate Education (1932)] & & -0.051 & $-0.239^{*}$ & 0.110 \\
\hline$\times$ Post 1933 & & $(0.102)$ & $(0.141)$ & $(0.116)$ \\
\hline $\mathbb{1}[0.20 \leq$ Importance of Jews for SocSci Graduate Education $(1932)<0.80]$ & & $-0.154^{* * *}$ & $-0.166^{*}$ & $-0.131^{* *}$ \\
\hline$\times$ Post 1933 & & $(0.057)$ & $(0.097)$ & $(0.062)$ \\
\hline $\mathbb{1}[0.80 \leq$ Importance of Jews for SocSci Graduate Education (1932)] & & $-0.261^{* * *}$ & $-0.278^{*}$ & $-0.189^{*}$ \\
\hline$\times$ Post 1933 & & $(0.078)$ & $(0.149)$ & $(0.111)$ \\
\hline Firm FE & Yes & Yes & Yes & Yes \\
\hline Time FE & Yes & Yes & Yes & Yes \\
\hline All Controls & Yes & Yes & Yes & Yes \\
\hline Number of Observations & 12710 & 12710 & 5198 & 7512 \\
\hline Number of Firms & 655 & 655 & 264 & 391 \\
\hline $\mathrm{R}^{2}$ & 0.627 & 0.626 & 0.693 & 0.638 \\
\hline
\end{tabular}

Notes: The dependent variable is the natural logarithm of the stock price. Stock prices are averaged in a plus-minus 10-day window around January 10th and July 10th of each year. The main explanatory variables are indicators for whether Jewish managers were responsible for: 1) less than 20 percent of all managerial characteristics analyzed in the given column, 2) 20 percent to less than 80 percent of the indicated managerial characteristic, and 3) more than 80 percent of the indicated managerial characteristic. For firms without Jewish managers in 1932, all of the reported indicator variables in all columns are zero. The main explanatory variables are all interacted with an indicator for the months after January 1933. In columns 2 to 4, we additionally control for indicators representing the share of Jewish managers with a graduate degree for which we cannot assign a field of study. Further control variables are identical to Table 4. In columns 1 and 2, the sample contains all firms listed in Berlin. In column 3, the sample contains firms in STEM industries, for example, pharmaceuticals or machinery production. In column 4, the sample contains firms in non-STEM industries, for example, banking or insurance. The data include the months January and July for the years from 1929 to 1943. Standard errors are clustered at the firm level. Significance levels: $* * * \mathrm{p}<0.01, * * \mathrm{p}<0.05$, and $* \mathrm{p}<0.1$. 


\section{Table 7: The Effect Among Firms Favored by the Nazis}

(1) (2)

Dep. Variable: $\log ($ Stock Price)

\begin{tabular}{|c|c|c|}
\hline $\begin{array}{l}\text { Frac. Jewish Managers (1932) } \\
\times \text { Post } 1933\end{array}$ & $\begin{array}{l}-0.576^{*} \\
(0.333)\end{array}$ & $\begin{array}{l}-0.704^{* *} \\
(0.313)\end{array}$ \\
\hline Firm FE & Yes & Yes \\
\hline Time FE & Yes & Yes \\
\hline All Controls & & Yes \\
\hline Number of Observations & 3834 & 3834 \\
\hline Number of Firms & 171 & 171 \\
\hline $\mathrm{R}^{2}$ & 0.563 & 0.663 \\
\hline
\end{tabular}

Notes: The dependent variable is the natural logarithm of the stock price. Stock prices are averaged in a plus-minus 10day window around January 10th and July 10th of each year. The main explanatory variable measures the fraction of Jewish managers in 1932, interacted with an indicator for the months after January 1933. The sample contains firms with connections to the Nazi Party and firms that received forced labor workers from the Nazi government, excluding firms historically perceived as Jewish. The control variables are identical to Table 4. The data include the months January and July for the years from 1929 to 1943 . Standard errors are clustered at the firm level. Significance levels: $* * * \mathrm{p}<0.01, * * \mathrm{p}<0.05$, and $* \mathrm{p}<0.1$.

Table 8: Jewish Managers Vs. Firms Perceived As Jewish

\begin{tabular}{lcccccc}
\hline & $(1)$ & $(2)$ & $(3)$ & $(4)$ & $(5)$ & $(6)$ \\
Dep. Variable: $\log$ (Stock Price) & & & & & & \\
\hline Jewish Firm & & & & & & \\
$\times$ Post 1933 & -0.127 & -0.137 & -0.021 & -0.041 & 0.029 & 0.007 \\
Jewish Firm & $(0.096)$ & $(0.084)$ & $(0.097)$ & $(0.090)$ & $(0.099)$ & $(0.092)$ \\
$\times$ Post 1935 & & & $-0.140^{* *}$ & $-0.128^{* *}$ & $-0.142^{* *}$ & $-0.131^{* *}$ \\
Frac. Jewish Managers (1932) & & & $(0.057)$ & $(0.059)$ & $(0.058)$ & $(0.060)$ \\
$\times$ Post 1933 & & & & & $-0.446^{* * *}$ & $-0.441^{* * *}$ \\
& & & & & $(0.138)$ & $(0.138)$ \\
Firm FE & Yes & Yes & Yes & Yes & Yes & Yes \\
Time FE & Yes & Yes & Yes & Yes & Yes & Yes \\
All Controls & & Yes & & Yes & & Yes \\
& & & & & & \\
Number of Observations & 12710 & 12710 & 12710 & 12710 & 12710 & 12710 \\
Number of Firms & 655 & 655 & 655 & 655 & 655 & 655 \\
$\mathrm{R}^{2}$ & 0.563 & 0.619 & 0.563 & 0.620 & 0.567 & 0.623 \\
\hline
\end{tabular}

Notes: The dependent variable is the natural logarithm of the stock price. Stock prices are averaged in a plus-minus 10day window around January 10th and July 10th of each year. The first main explanatory variable is an indicator for firms historically perceived as Jewish, interacted with an indicator for the months after January 1933. The second main explanatory variable is an indicator for firms historically perceived as Jewish, interacted with an indicator for the months after January 1935. The third main explanatory variable measures the fraction of Jewish managers in 1932, interacted with an indicator for the months after January 1933. The control variables are identical to Table 4 . The data include the months January and July for the years from 1929 to 1943 . Standard errors are clustered at the firm level. Significance levels: $* * * \mathrm{p}<0.01, * * \mathrm{p}<0.05$, and $* \mathrm{p}<0.1$. 


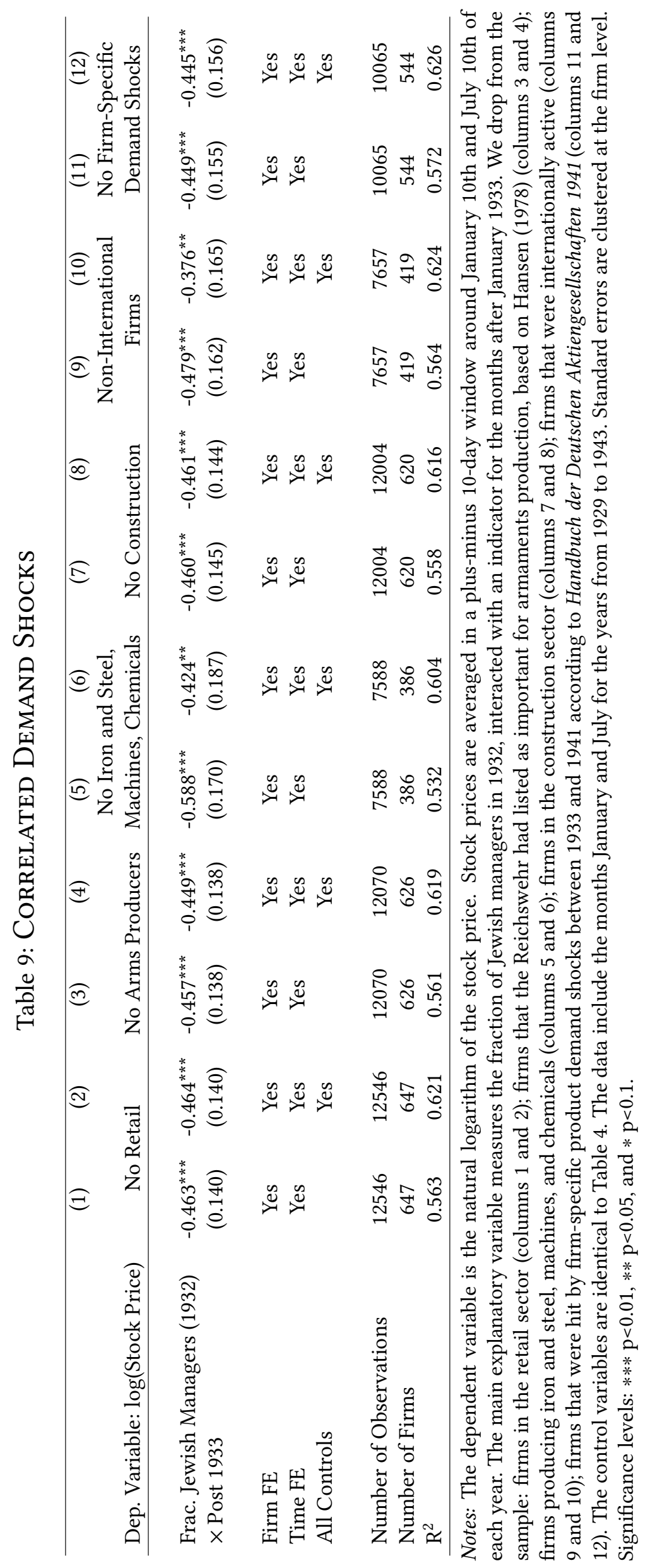


Table 10: The Effect on Dividends And Returns on Assets

\begin{tabular}{lcccc}
\hline & $(1)$ & $(2)$ & $(3)$ & $(4)$ \\
Dep. Variable: & \multicolumn{2}{c}{ Dividends } & Return on Assets \\
\hline Frac. Jewish Managers (1932) & -1.266 & $-1.557^{* *}$ & $-0.235^{* *}$ & $-0.187^{* *}$ \\
$\times$ Post 1933 & $(0.960)$ & $(0.778)$ & $(0.105)$ & $(0.079)$ \\
& & & & \\
Firm FE & Yes & Yes & Yes & Yes \\
Time FE & Yes & Yes & Yes & Yes \\
All Controls & & Yes & & Yes \\
& & & & \\
Number of Observations & 7379 & 7379 & 492 & 492 \\
Number of Firms & 655 & 655 & 289 & 289 \\
$\mathrm{R}^{2}$ & 0.176 & 0.240 & 0.401 & 0.560 \\
\hline
\end{tabular}

Notes: The dependent variable in columns 1 and 2 is the annual dividend payment, measured as a percentage of the nominal stock value. The data in columns 1 and 2 include the years 1929 to 1943 . The dependent variable in columns 3 and 4 is the return on assets, measured as the ratio of profits before interest payments and taxes to total assets. The data in columns 3 and 4 include the years 1931, 1936, and 1940. The main explanatory variable measures the fraction of Jewish managers in 1932 , interacted with an indicator for the months after January 1933. The control variables are identical to Table 4. Standard errors are clustered at the firm level. Significance levels: $* * * \mathrm{p}<0.01, * * \mathrm{p}<0.05$, and $* \mathrm{p}<0.1$. 


\section{A Online Appendix Figures and Tables}

\section{Figure A.1: The Effect on the Characteristics of Firms' Senior Management (With All Controls)}

(a) Managers With Tenure Since 1928

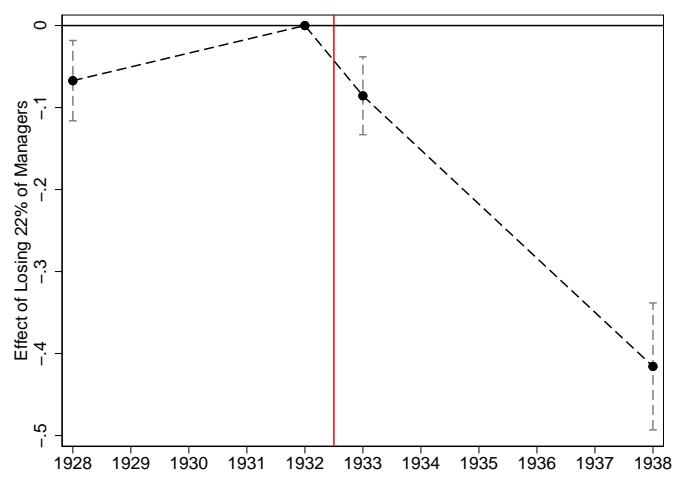

(c) Managers With University Education

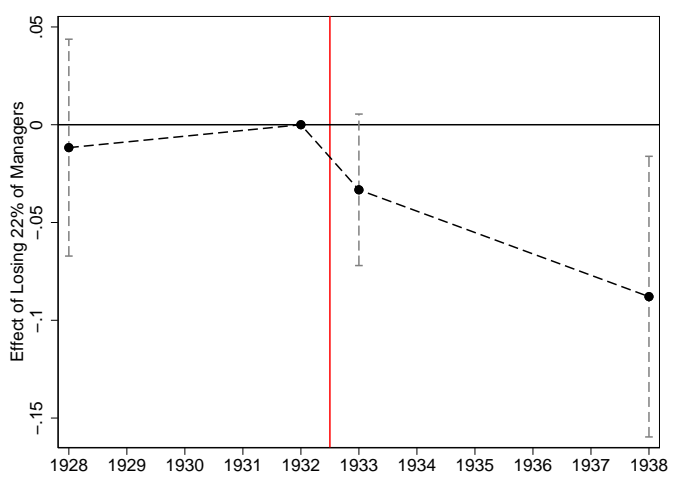

(b) Managers With Experience Since 1928

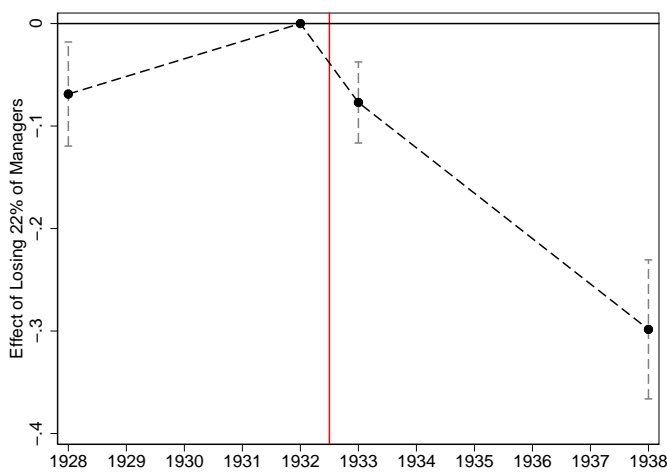

(d) Connections

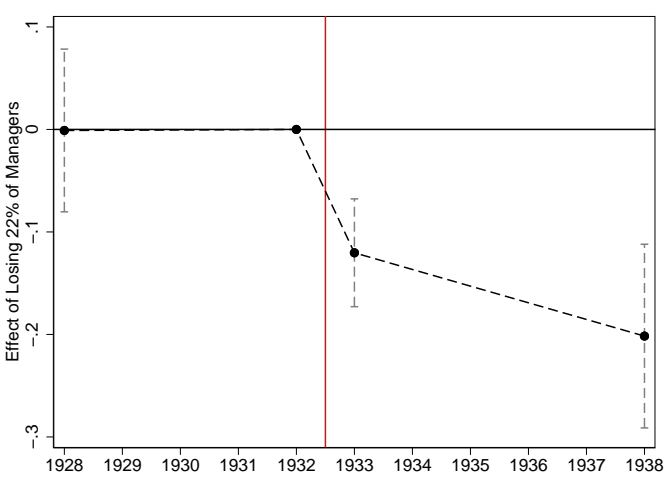

Notes: The figure reports yearly coefficients $\left(\beta_{\tau}\right)$ and 95 percent confidence intervals from equation 1 . Each panel reports results for a different dependent variable, as indicated in the heading of the panel. The dependent variables are in natural logarithms. The main explanatory variables are the fraction of Jewish managers in 1932, interacted with a fixed effect for each year. The interaction with 1932, the last year before the Nazis gained power, is the excluded interaction. Coefficients and standard errors are scaled to reflect the effect on the average firm with Jewish managers in 1932. The average such firm lost 22 percent of its managers after 1932. All regressions include firm and year fixed effects and the following control variables: an indicator for any connections to the Nazi Party, an indicator for whether the firm published its 1932 financial statement in January, firm age in 1932, firm nominal capital in 1932, and industry fixed effects. All controls are interacted with a full set of year fixed effects. The data include the years 1928, 1932, 1933, and 1938. Standard errors are clustered at the firm level. 
Figure A.2: The Effect on Stock Prices, Adjusted for Dividend Payments

(a) With Firm and Year Fixed Effects

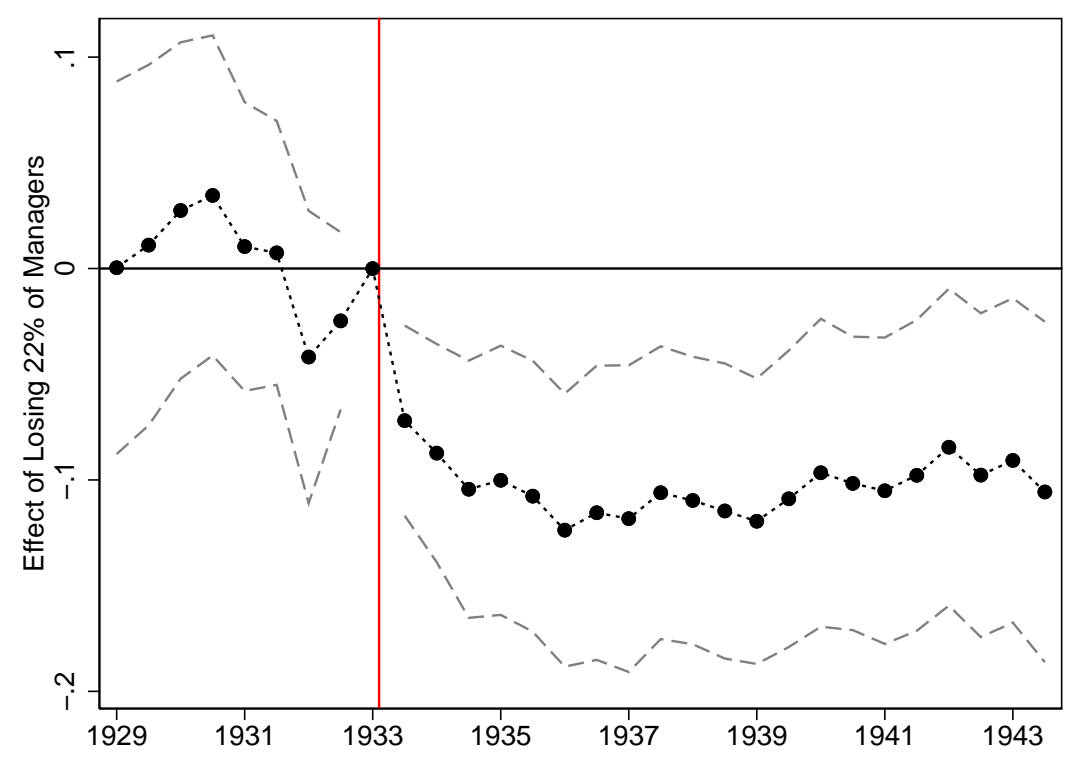

(b) With All Controls

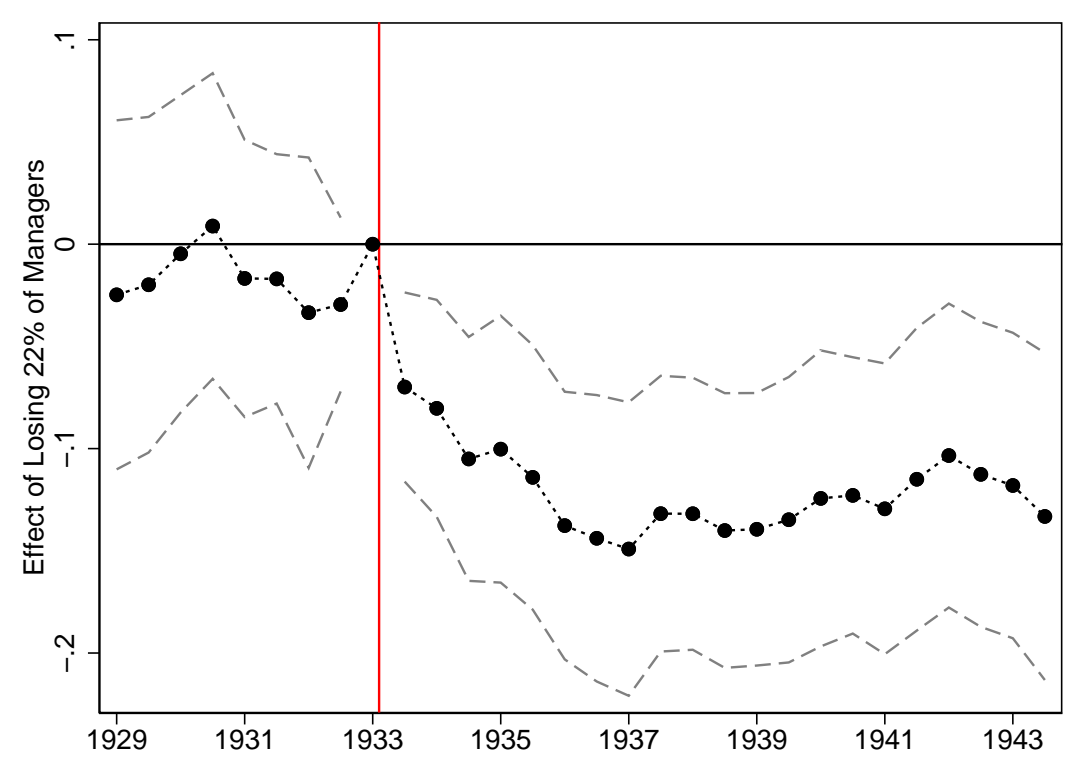

Notes: This figure is identical to Figure 3, except that the stock prices in the dependent variable are adjusted for dividend payments. We adjust for dividend payments by assuming that investors immediately reinvest the dividend paid out by a firm into the stock of that firm (see Appendix B.2.3 for details). This adjustment means that the coefficients measure the effect of losing Jewish managers on the return of investing (on January 10,1933) into the average firm with Jewish managers in 1932, relative to investing into a firm without Jewish managers in 1932. 
Figure A.3: Stock Price Changes 1933-1938

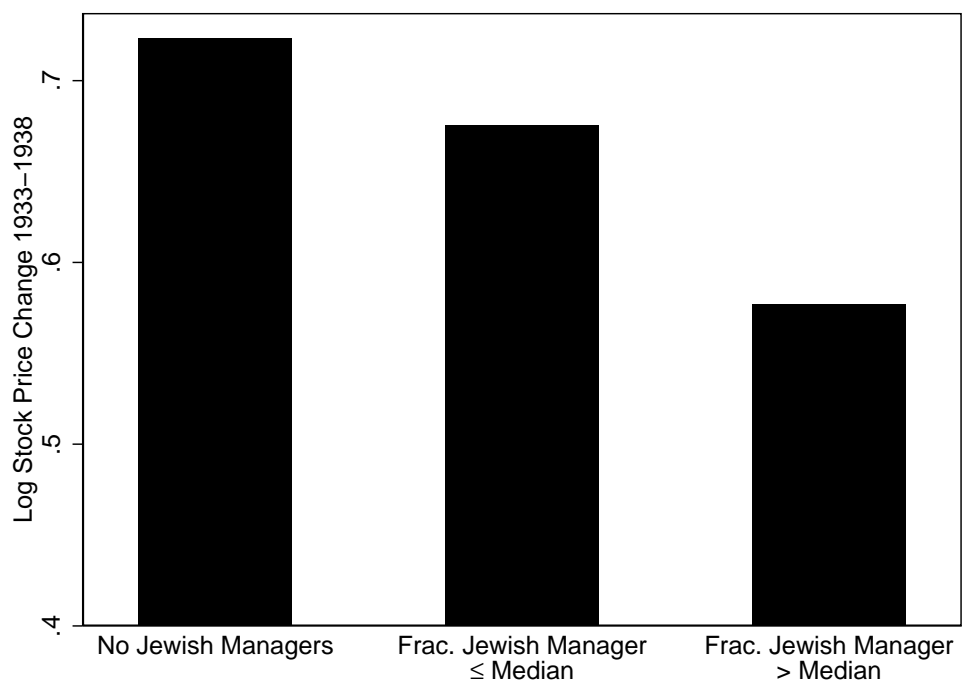

Notes: The figure shows the average log stock price change between January 1933 (before the Nazis came to power) and July 1938 (when virtually no Jewish managers remained in German firms). We plot the average stock price change for three groups of firms: firms without Jewish managers in 1932; firms where the fraction of Jewish managers in 1932 was positive but below the median; and firms where the fraction of Jewish managers in 1932 was above the median. The stock market generally trended upward from 1933 to 1938. But stock prices increased less for firms that had employed a higher fraction of Jewish managers in 1932. 


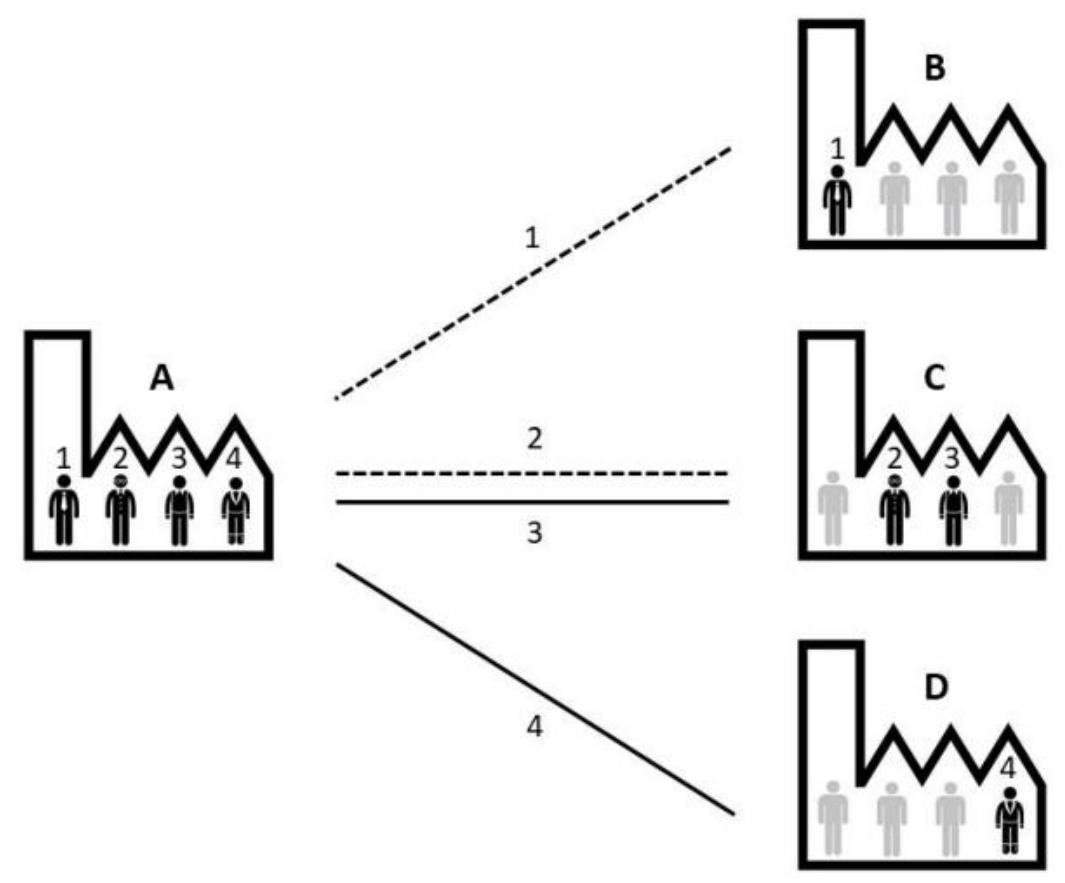

Notes: The figure shows a simple example of firm connections through managers. The focal firm is firm A, which employed managers 1-4. Managers 1 and 2 were Jewish. Manager 1 was connected to firm B; managers 2 and 3 to firm C; and manager 4 to firm D. Hence, firm A had 3 connections overall. Jewish managers were responsible for the full link to firm B, 0.5 of the link to firm C, and 0 of the link to firm D. Hence, for firm A:

Importance of Jews for Managerial Connections $(1932)=\frac{(\overbrace{1}+\overbrace{0.5}+\overbrace{0})}{3}=0.5$.

\section{Figure A.5: Example of a Second Degree Managerial Connection}

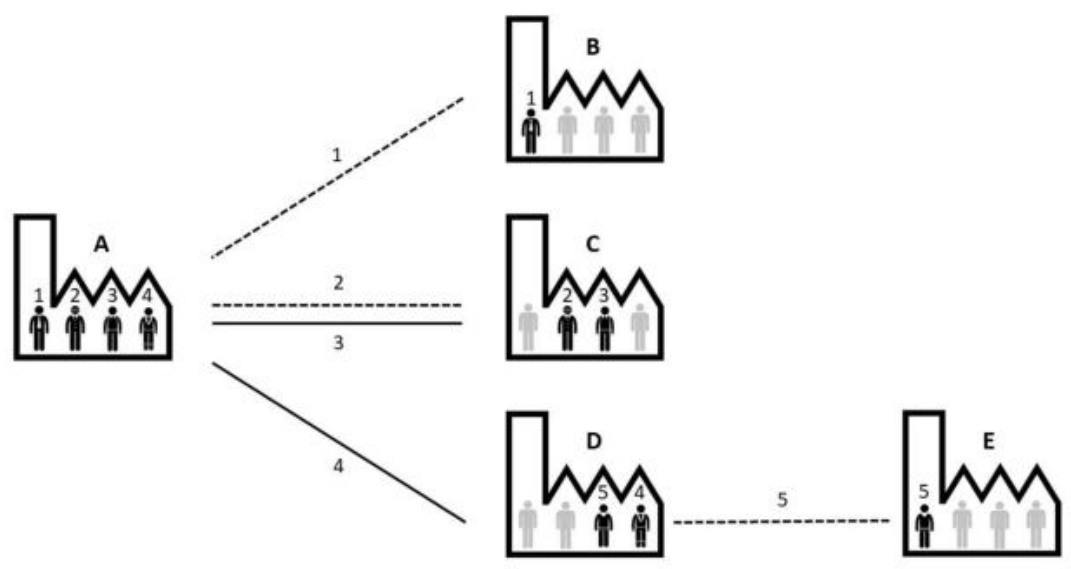

Notes: The figure shows a simple example of firm connections through managers. The focal firm is firm A, which employed managers 1-4. Managers 1 and 2 were Jewish. Firms D and E employed another manager 5 who was also Jewish. Manager 5 was responsible for a second degree link between firm A and firm E. 
Figure A.6: The Effect on Stock Prices of Firms Perceived As Jewish

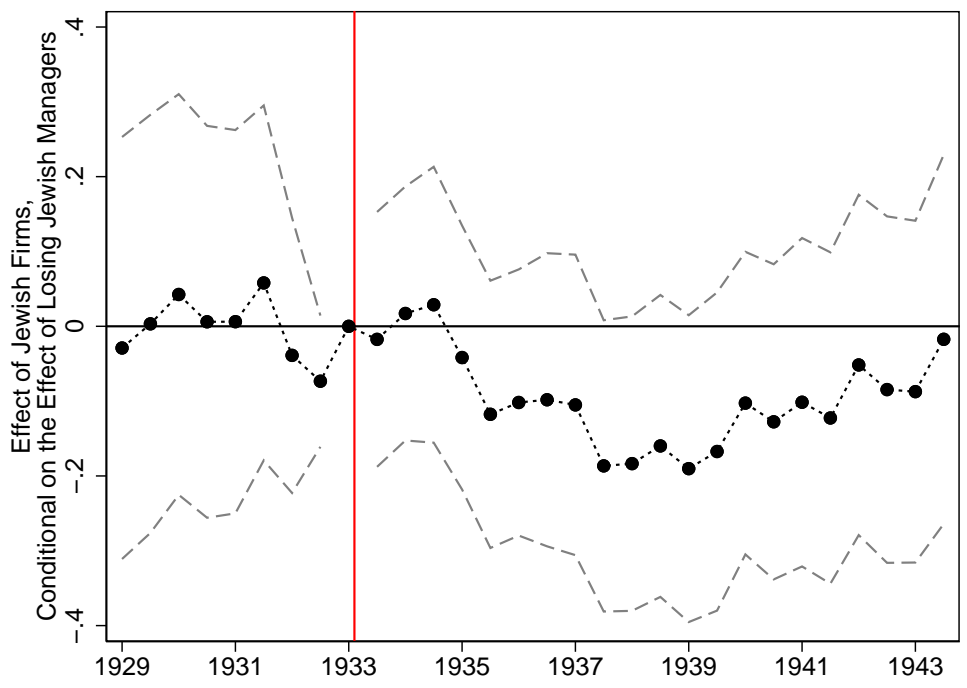

Notes: The figure reports coefficients $\left(\beta_{\tau}\right)$ and 95 percent confidence intervals from a regression similar to equation 3 . The dependent variable is the natural logarithm of the stock price. Stock prices are averaged in a plus-minus 10 -day window around January 10th and July 10th of each year. The main explanatory variable is an indicator for whether the firm was perceived as Jewish by contempories, interacted with a fixed effect for each time period. The interaction with January 1933, the last period before the Nazis gained power, is the excluded interaction. The regression also controls for the fraction of Jewish managers in 1932, interacted with a full set of time fixed effects, and all controls used in Figure 3, panel (b). Standard errors are clustered at the firm level.

\section{Figure A.7: The Share of Jews in Region-Sector Cells With Few Lower-Ranked JEWISH EMPLOYEES}

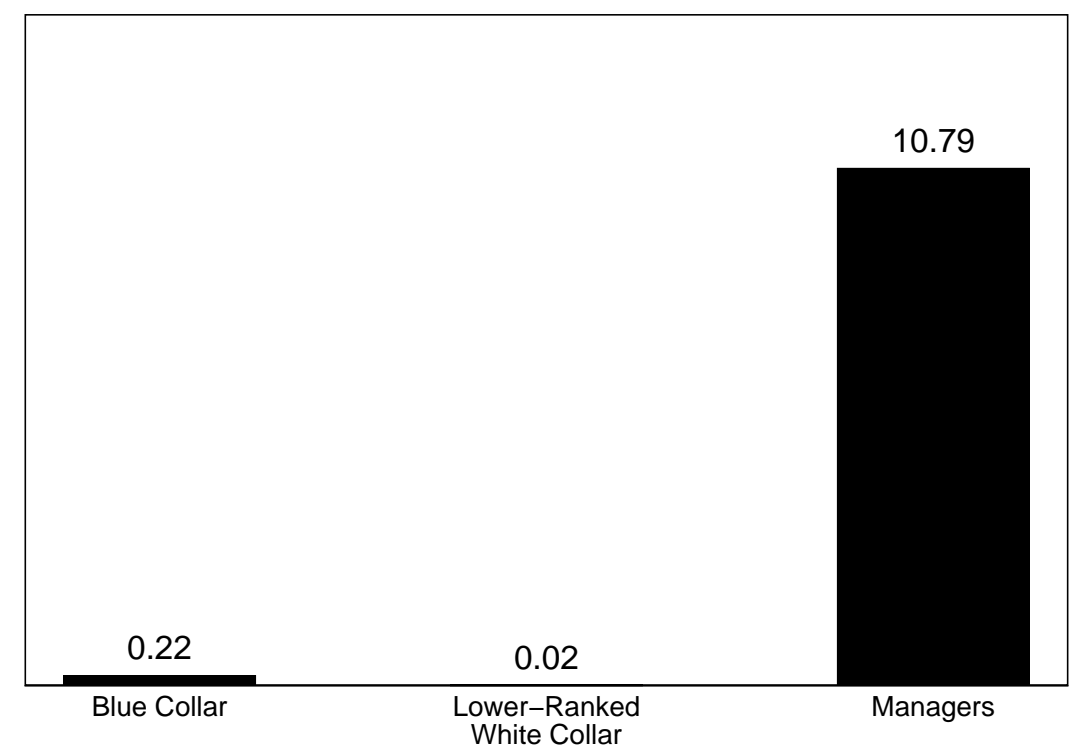

Notes: The figure reports the average percentage of blue collar workers (left bar), lower-ranked white color workers (middle bar) and managers (right bar) in the sample of firms in region-sector cells with the lowest quartiles of both blue collar workers and lower-ranked white collar employees. This sample is equivalent to the estimation sample for columns 5 and 6 in Appendix Table A.15. The data on lower-ranked employees are from the 1933 census (see Appendix Section B.5 for details). The data on managers are from Handbuch der Deutschen Aktiengesellschaften 1932. 
Table A.1: Robustness to Alternative Stock Price Measures

\begin{tabular}{lcccccccc}
\hline & $(1)$ & $(2)$ & $(3)$ & $(4)$ & $(5)$ & $(6)$ & $(7)$ & $(8)$ \\
Dep. Variable: $\log ($ Stock Price) & \multicolumn{2}{c}{ Exclude 1932} & 5-day Window & 3-day Window & Monthly Stock Prices \\
\hline & & & & & & & & \\
Frac. Jewish Managers (1932) & $-0.530^{* * *}$ & $-0.512^{* * *}$ & $-0.484^{* * *}$ & $-0.468^{* * *}$ & $-0.489^{* * *}$ & $-0.467^{* * *}$ & $-0.456^{* * *}$ & $-0.445^{* * *}$ \\
$\times$ Post 1933 & $(0.148)$ & $(0.149)$ & $(0.141)$ & $(0.139)$ & $(0.144)$ & $(0.142)$ & $(0.137)$ & $(0.137)$ \\
& & & & & & & & \\
Firm FE & Yes & Yes & Yes & Yes & Yes & Yes & Yes & Yes \\
Time FE & Yes & Yes & Yes & Yes & Yes & Yes & Yes & Yes \\
All Controls & & Yes & & Yes & & Yes & & Yes \\
& & & & & & & & \\
Number of Observations & 11841 & 11841 & 11781 & 11781 & 11330 & 11330 & 12762 & 12762 \\
Number of Firms & 655 & 655 & 653 & 653 & 653 & 653 & 654 & 654 \\
$\mathrm{R}^{2}$ & 0.502 & 0.565 & 0.554 & 0.612 & 0.545 & 0.605 & 0.571 & 0.626 \\
\hline
\end{tabular}

Notes: The dependent variable is the natural logarithm of the stock price. Stock prices are averaged in a plus-minus 10-day window (columns 1 and 2), plus-minus five-day window (columns 3 and 4), or plus-minus three-day window (columns 5 and 6) around January 10th and July 10th of each year. Stock prices in columns 7 and 8 are averaged over the entire month of January and July of each year. We exclude the observations for 1932 in columns 1 and 2 . The main explanatory variable measures the fraction of Jewish managers in 1932, interacted with an indicator for the months after January 1933. The control variables are identical to Table 4. The data include the months January and July for the years from 1929 to 1943. Standard errors are clustered at the firm level. Significance levels: $* * * \mathrm{p}<0.01, * * \mathrm{p}<0.05$, and $* \mathrm{p}<0.1$. 


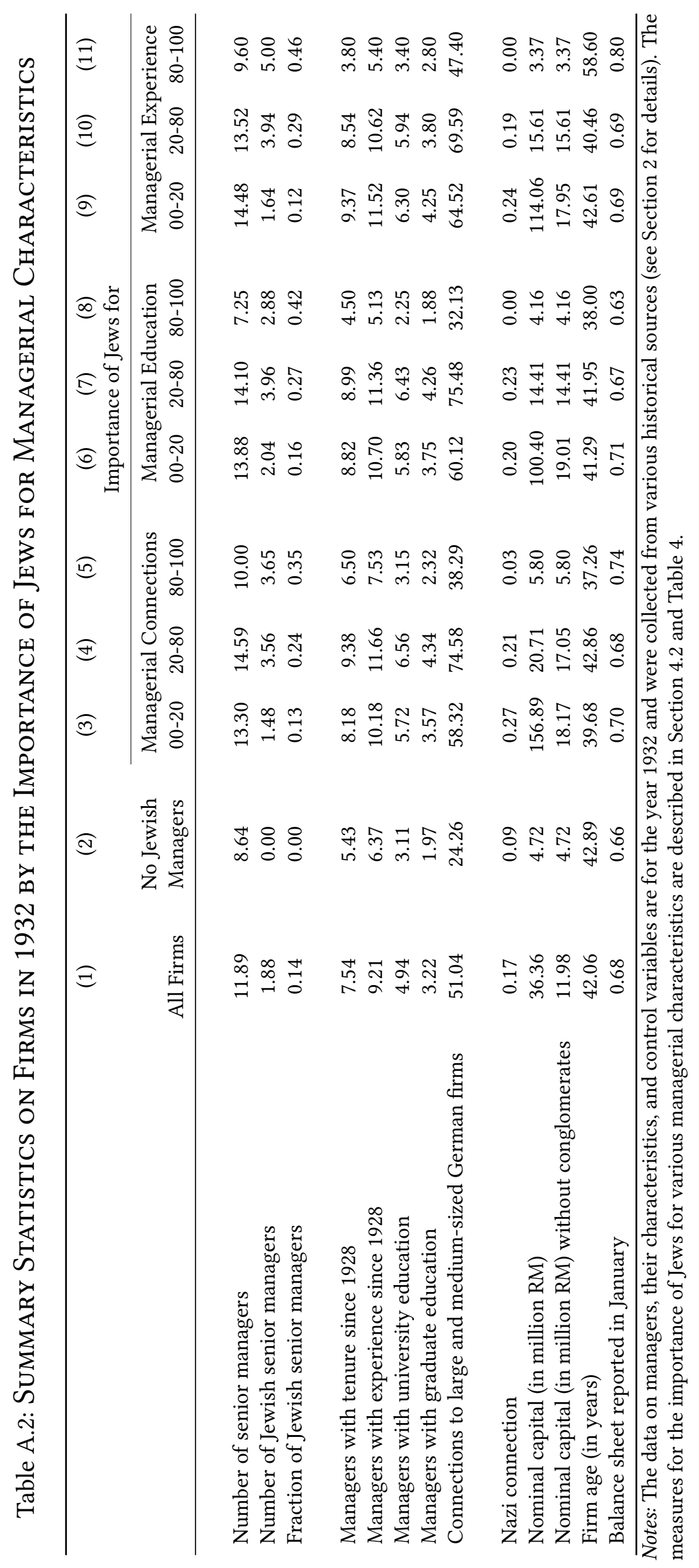


Table A.3: The Effect on the Characteristics of Firms' Senior Management, UsING THE INVERSE HyPERBolic Sine

\begin{tabular}{|c|c|c|c|c|}
\hline Dep. Variable: & $\begin{array}{c}(1) \\
\text { \# of Managers } \\
\text { with Tenure } \\
\text { since } 1928\end{array}$ & $\begin{array}{c}(2) \\
\text { \# of Managers } \\
\text { with Experience } \\
\text { since } 1928\end{array}$ & $\begin{array}{c}\text { (3) } \\
\text { \# of Managers } \\
\text { with University } \\
\text { Education }\end{array}$ & $\begin{array}{c}\text { (4) } \\
\text { \# of } \\
\text { Connections }\end{array}$ \\
\hline $\begin{array}{l}\text { Frac. Jewish Managers (1932) } \\
\times \text { Post } 1933\end{array}$ & $\begin{array}{l}-0.971^{* * *} \\
(0.116)\end{array}$ & $\begin{array}{c}-0.689^{* * *} \\
(0.097)\end{array}$ & $\begin{array}{l}-0.225^{* *} \\
(0.093)\end{array}$ & $\begin{array}{c}-0.627^{* * *} \\
(0.156)\end{array}$ \\
\hline $\begin{array}{l}\text { Firm FE } \\
\text { Time FE }\end{array}$ & $\begin{array}{l}\text { Yes } \\
\text { Yes }\end{array}$ & $\begin{array}{l}\text { Yes } \\
\text { Yes }\end{array}$ & $\begin{array}{l}\text { Yes } \\
\text { Yes }\end{array}$ & $\begin{array}{l}\text { Yes } \\
\text { Yes }\end{array}$ \\
\hline $\begin{array}{l}\text { Number of Observations } \\
\text { Number of Firms } \\
\mathrm{R}^{2}\end{array}$ & $\begin{array}{c}2538 \\
655 \\
0.714\end{array}$ & $\begin{array}{c}2538 \\
655 \\
0.634 \\
\end{array}$ & $\begin{array}{c}2538 \\
655 \\
0.011 \\
\end{array}$ & $\begin{array}{c}2538 \\
655 \\
0.256\end{array}$ \\
\hline
\end{tabular}

Notes: The heading of each column lists the dependent variable. All dependent variables are transformed using the inverse hyperbolic sine, an approximation to the log that permits using zero values. The main explanatory variable measures the fraction of Jewish managers in 1932, interacted with an indicator for the years after 1932. The data include the years 1928, 1932, 1933, and 1938. Standard errors are clustered at the firm level. Significance levels: $* * * \mathrm{p}<0.01, * * \mathrm{p}<0.05$, and $* \mathrm{p}<0.1$. 
Table A.4: The Effect on the Characteristics of Firms' Senior Management (BiNARY TREATMENT INDICATOR)
(1)
(2)
(3)
(4)
(5)
(6)

Panel A: Dep. Variable: $\log$ (\# of Managers with Tenure since 1928), \# of obs./firms: 2412/655

\begin{tabular}{lcccccc} 
Firm with Jewish Managers (1932) & $-0.229^{* * *}$ & $-0.229^{* * *}$ & $-0.228^{* * *}$ & $-0.227^{* * *}$ & $-0.228^{* * *}$ & $-0.219^{* * *}$ \\
$\times$ Post 1933 & $(0.031)$ & $(0.031)$ & $(0.031)$ & $(0.031)$ & $(0.031)$ & $(0.032)$ \\
$\mathrm{R}^{2}$ & 0.746 & 0.746 & 0.747 & 0.747 & 0.747 & 0.755 \\
\hline
\end{tabular}

Panel B: Dep. Variable: $\log$ (\# of Managers with Experience since 1928), \# of obs./firms: 2493/655

\begin{tabular}{lcccccc} 
Firm with Jewish Managers (1932) & $-0.154^{* * *}$ & $-0.168^{* * *}$ & $-0.167^{* * *}$ & $-0.165^{* * *}$ & $-0.163^{* * *}$ & $-0.157^{* * *}$ \\
$\times$ Post 1933 & $(0.030)$ & $(0.030)$ & $(0.030)$ & $(0.030)$ & $(0.030)$ & $(0.031)$ \\
$\mathrm{R}^{2}$ & 0.656 & 0.660 & 0.660 & 0.662 & 0.662 & 0.677 \\
\hline
\end{tabular}

Panel C: Dep. Variable: $\log$ (\# of Managers with University Education), \# of obs./firms: 2408/645

\begin{tabular}{lcccccc} 
Firm with Jewish Managers (1932) & $-0.151^{* * *}$ & $-0.140^{* * *}$ & $-0.141^{* * *}$ & $-0.138^{* * *}$ & $-0.138^{* * *}$ & $-0.130^{* * *}$ \\
$\times$ Post 1933 & $(0.032)$ & $(0.032)$ & $(0.032)$ & $(0.032)$ & $(0.032)$ & $(0.032)$ \\
$\mathrm{R}^{2}$ & 0.025 & 0.029 & 0.030 & 0.037 & 0.037 & 0.060 \\
\hline
\end{tabular}

Panel D: Dep. Variable: $\log$ (\# of Connections), \# of obs./firms: 2510/655

\begin{tabular}{lcccccc} 
Firm with Jewish Managers (1932) & $-0.198^{* * *}$ & $-0.210^{* * *}$ & $-0.211^{* * *}$ & $-0.208^{* * *}$ & $-0.210^{* * *}$ & $-0.198^{* * *}$ \\
$\times$ Post 1933 & $(0.046)$ & $(0.046)$ & $(0.046)$ & $(0.046)$ & $(0.046)$ & $(0.046)$ \\
$\mathrm{R}^{2}$ & 0.253 & 0.255 & 0.259 & 0.260 & 0.261 & 0.281 \\
\hline & & & & & & \\
Firm FE & Yes & Yes & Yes & Yes & Yes & Yes \\
Time FE & Yes & Yes & Yes & Yes & Yes & Yes \\
Nazi Connection $\times$ Time FE & & Yes & Yes & Yes & Yes & Yes \\
Reporting Period $\times$ Time FE & & & Yes & Yes & Yes & Yes \\
Firm Age $\times$ Time FE & & & & Yes & Yes & Yes \\
Nominal Capital $\times$ Time FE & & & & & Yes & Yes \\
Industry FE $\times$ Time FE & & & & & Yes \\
\hline
\end{tabular}

Notes: The heading of each panel lists the relevant dependent variable. The main explanatory variable is an indicator for whether the firm had any Jewish managers in 1932, interacted with an indicator for the years after 1932. The control variables are identical to Table 3. The data include the years 1928, 1932, 1933, and 1938. Standard errors are clustered at the firm level. Significance levels: $* * * \mathrm{p}<0.01, * * \mathrm{p}<0.05$, and $* \mathrm{p}<0.1$. 
Table A.5: The Effect on the Total Number of Managers

\begin{tabular}{lcccc}
\hline & $(1)$ & $(2)$ & $(3)$ & $(4)$ \\
Dep. Variable: & \# of Managers & log(\# of Managers) \\
\hline & & & & \\
Jewish Managers (1932) & 0.072 & & 0.007 & \\
$\times$ Post 1933 & $(0.099)$ & & $(0.004)$ & \\
Frac. Jewish Managers (1932) & & 0.346 & & -0.085 \\
$\times$ Post 1933 & & $(0.944)$ & & $(0.057)$ \\
& & & & \\
Firm FE & Yes & Yes & Yes & Yes \\
Time FE & Yes & Yes & Yes & Yes \\
All Controls & Yes & Yes & Yes & Yes \\
& & & & \\
Number of Observations & 2538 & 2538 & 2538 & 2538 \\
Number of Firms & 655 & 655 & 655 & 655 \\
$\mathrm{R}^{2}$ & 0.429 & 0.429 & 0.359 & 0.358 \\
\hline
\end{tabular}

Notes: The dependent variable in columns 1 and 2 is the number of managers. The dependent variable in columns 3 and 4 is the natural logarithm of the number of managers. The first explanatory variable measures the number of Jewish managers in 1932. The second explanatory variable measures the fraction of Jewish managers in 1932. The two explanatory variables are interacted with an indicator for the years after 1932. The control variables include: an indicator for any connections to the Nazi Party, an indicator for whether the firm published its 1932 financial statement in January, firm age in 1932, firm nominal capital in 1932, and industry fixed effects. We also control for the log of the total number of managers in 1928 because there was a secular decrease in the number of managers in firms that had large boards in 1928. All controls are interacted with a full set of year fixed effects. The data include the years 1928, 1932, 1933, and 1938. Standard errors are clustered at the firm level. Significance levels: $* * * \mathrm{p}<0.01, * * \mathrm{p}<0.05$, and $* \mathrm{p}<0.1$. 
Table A.6: Robustness to VARious Industry Classifications

\begin{tabular}{lcccc}
\hline & $(1)$ & $(2)$ & $(3)$ & $(4)$ \\
Dep. Variable: $\log$ (Stock Price) & & & & \\
\hline & & & & \\
Frac. Jewish Managers (1932) & $-0.464^{* * *}$ & $-0.432^{* * *}$ & $-0.436^{* * *}$ & $-0.433^{* * *}$ \\
$\times$ Post 1933 & $(0.138)$ & $(0.135)$ & $(0.139)$ & $(0.141)$ \\
& & & & \\
Firm FE & Yes & Yes & Yes & Yes \\
Time FE & Yes & Yes & Yes & Yes \\
All Other Controls & Yes & Yes & Yes & Yes \\
Industry FE (10 Categories) & Yes & & & \\
Industry FE (22 Categories) & & Yes & & \\
Industry FE (43 Categories) & & & Yes & Yes \\
& & & & \\
Number of Observations & 12710 & 12710 & 12710 & 11962 \\
Number of Firms & 655 & 655 & 655 & 620 \\
$\mathrm{R}^{2}$ & 0.622 & 0.648 & 0.688 & 0.679 \\
\hline
\end{tabular}

Notes: The dependent variable is the natural logarithm of the stock price. Stock prices are averaged in a plus-minus 10-day window around January 10th and July 10th of each year. The main explanatory variable measures the fraction of Jewish managers in 1932, interacted with an indicator for the months after January 1933. In column 1, we control for 10 industry fixed effects, interacted with 30 time dummies. The industry categorization is based on Ziegler (2000b). In column 2, we control for 22 industry fixed effects, interacted with 30 time dummies. The industry categorization is based on the sectoral classification in Handbuch der Deutschen Aktiengesellschaften 1932. In column 3, we control for 43 industry fixed effects, interacted with 30 time dummies. This industry categorization is hand-coded using detailed narrative descriptions of each firm's activities in Handbuch der Deutschen Aktiengesellschaften. In column 4, we use the same industry classification as in column 3 but drop industries with fewer than 5 firms. The control variables are identical to Table 4 . The data include the months January and July for the years from 1929 to 1943. Standard errors are clustered at the firm level. Significance levels: $* * * \mathrm{p}<0.01, * * \mathrm{p}<0.05$, and $* \mathrm{p}<0.1$.

Table A.7: The Effect on Stock Prices (Binary Treatment Indicator)
$(1)$
(2)
(3)
(4)
(5)
(6)

Dep. Variable: $\log ($ Stock Price)

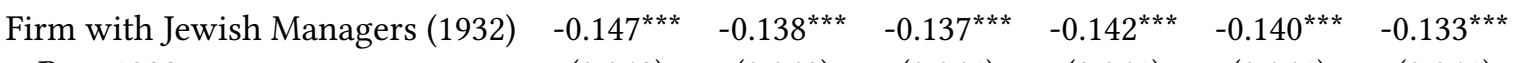

$\times$ Post 1933

(0.043)

$(0.042)$

$(0.041)$

$(0.041)$

(0.041)

(0.041)

Firm FE

Time FE

Yes

Nazi Connection $\times$ Time FE

Yes

$\begin{array}{ll}\text { Yes } & \text { Yes } \\ \text { Yes } & \text { Yes } \\ \text { Yes } & \text { Yes } \\ & \text { Yes }\end{array}$

Yes

Yes

Yes

Reporting Period $\times$ Time FE

Yes

Yes Yes

Firm Age $\times$ Time FE

Nominal Capital $\times$ Time FE

Industry $\mathrm{FE} \times$ Time FE

Number of Observations
Number of Firms
$\mathrm{R}^{2}$

\begin{tabular}{cccccc}
12710 & 12710 & 12710 & 12710 & 12710 & 12710 \\
655 & 655 & 655 & 655 & 655 & 655 \\
0.566 & 0.568 & 0.570 & 0.579 & 0.581 & 0.621 \\
\hline
\end{tabular}

Notes: The dependent variable is the natural logarithm of the stock price. Stock prices are averaged in a plus-minus 10-day window around January 10th and July 10th of each year. The main explanatory variable is an indicator for whether the firm had any Jewish managers in 1932, interacted with an indicator for the months after January 1933. The control variables are identical to Table 4. The data include the months January and July for the years from 1929 to 1943 . Standard errors are clustered at the firm level. Significance levels: $* * * \mathrm{p}<0.01, * * \mathrm{p}<0.05$, and $* \mathrm{p}<0.1$. 
Table A.8: The Effect of Dismissals in 1933 And Dismissals After 1933

(1) (2)

Dep. Variable: $\log ($ Stock Price)

Firms with dismissals in 1933

Frac. Jewish Managers (1932)

$\times \mathbb{1}(1933)$

$-0.408^{* * *}-0.343^{* *}$

Frac. Jewish Managers (1932)

$(0.154) \quad(0.157)$

$\times$ Post 1934

$-0.534^{* * *}-0.490^{* * *}$

$(0.146) \quad(0.149)$

Firms with all dismissals after 1933

Frac. Jewish Managers (1932) $\quad-0.100 \quad 0.039$

$\times \mathbb{1}(1933)$

$(0.217) \quad(0.209)$

Frac. Jewish Managers (1932) $\quad-0.307 \quad-0.440^{* *}$

$\times$ Post 1934

$(0.235) \quad(0.224)$

\begin{tabular}{lcc} 
Firm FE & Yes & Yes \\
Time FE & Yes & Yes \\
All Controls & & Yes \\
& & \\
Number of Observations & 12710 & 12710 \\
Number of Firms & 655 & 655 \\
$\mathrm{R}^{2}$ & 0.567 & 0.622 \\
\hline
\end{tabular}

Notes: The dependent variable is the natural logarithm of the stock price. Stock prices are averaged in a plus-minus 10-day window around January 10th and July 10th of each year. The main explanatory variables measures the fraction of Jewish managers in 1932, interacted with an indicator for (a) July 1933, (b) January 1934 and all months after, (c) July 1933 in firms with dismissals after 1933, and (d) January 1934 and all months after in firms with dismissals after 1933. The control variables are identical to Table 4. The data include the months January and July for the years from 1929 to 1943 . Standard errors are clustered at the firm level. Significance levels: $* * * \mathrm{p}<0.01, * * \mathrm{p}<0.05$, and $* \mathrm{p}<0.1$.

\section{Table A.9: Firms With At Least One Jewish Manager}

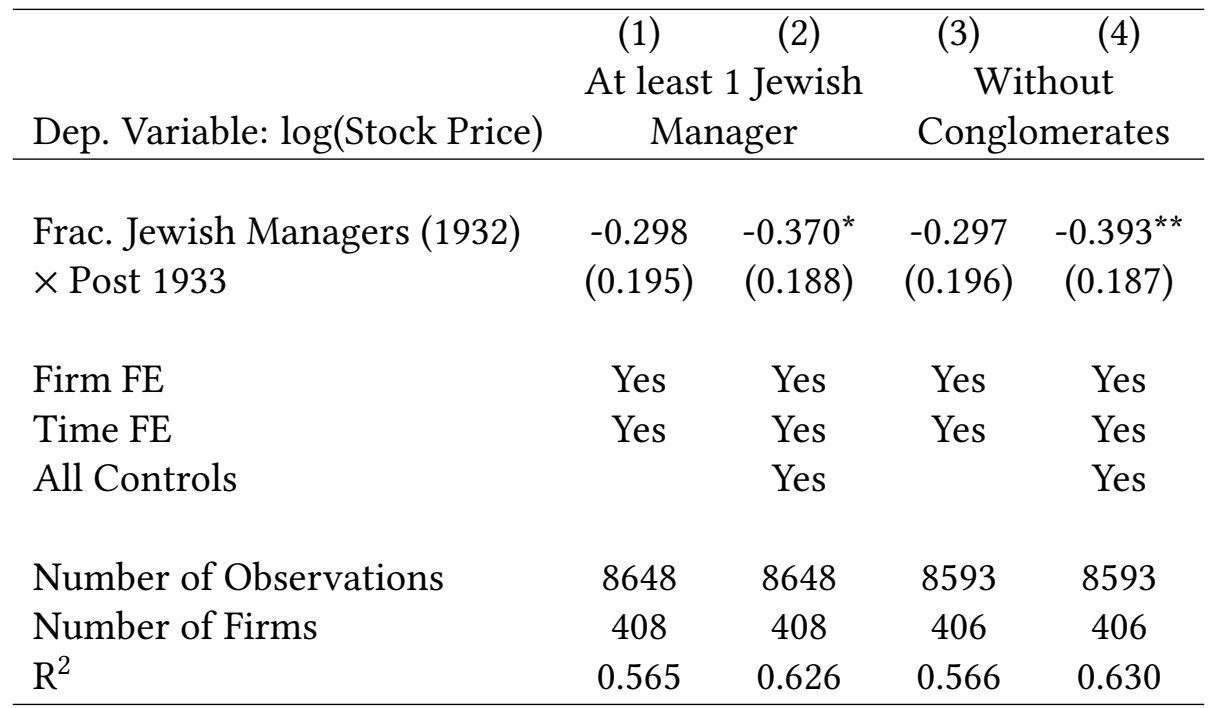

Notes: The dependent variable is the natural logarithm of the stock price. Stock prices are averaged in a plus-minus 10-day window around January 10th and July 10th of each year. The sample contains all firms with at least one Jewish manager. In addition, we drop two conglomerate firms in columns 3 and 4. The main explanatory variable measures the fraction of Jewish managers in 1932, interacted with an indicator for the months after January 1933. The control variables are identical to Table 4. The data include the months January and July for the years from 1929 to 1943 . Standard errors are clustered at the firm level. Significance levels: $* * * \mathrm{p}<0.01, * * \mathrm{p}<0.05$, and $* \mathrm{p}<0.1$. 
Table A.10: Firms Not in Cartels Vs. Firms in Cartels

\begin{tabular}{lcccc}
\hline & $(1)$ & $(2)$ & $(3)$ & $(4)$ \\
Dep. Variable: $\log$ (Stock Price) & Firms Not in Cartels & Firms in Cartels \\
\hline & & & & \\
Frac. Jewish Managers (1932) & $-0.552^{* * *}$ & $-0.471^{* * *}$ & -0.195 & -0.307 \\
$\times$ Post 1933 & $(0.165)$ & $(0.159)$ & $(0.211)$ & $(0.232)$ \\
& & & & \\
Firm FE & Yes & Yes & Yes & Yes \\
Time FE & Yes & Yes & Yes & Yes \\
All Controls & & Yes & & Yes \\
& & & & \\
Number of Observations & 9433 & 9433 & 3277 & 3277 \\
Number of Firms & 495 & 495 & 160 & 160 \\
$\mathrm{R}^{2}$ & 0.540 & 0.612 & 0.665 & 0.715 \\
\hline
\end{tabular}

Notes: The dependent variable is the natural logarithm of the stock price. Stock prices are averaged in a plus-minus 10-day window around January 10th and July 10th of each year. The main explanatory variable measures the fraction of Jewish managers in 1932, interacted with an indicator for the months after January 1933. In columns 1 and 2, the sample contains firms that were not members of a cartel. In columns 3 and 4, the sample contains firms that were members of a cartel. The control variables are identical to Table 4. The data include the months January and July for the years from 1929 to 1943. Standard errors are clustered at the firm level. Significance levels: $* * * \mathrm{p}<0.01, * * \mathrm{p}<0.05$, and $* \mathrm{p}<0.1$.

\section{Table A.11: Heterogeneity by Industry Dependence on Managers}

\begin{tabular}{|c|c|c|c|c|}
\hline \multirow[b]{3}{*}{ Dep. Variable: $\log ($ Stock Price) } & (1) & (2) & (3) & (4) \\
\hline & \multicolumn{4}{|c|}{$\begin{array}{l}\text { Industry Heterogeneity According to: } \\
\text { Share of Managers }\end{array}$} \\
\hline & \multicolumn{2}{|c|}{ Below Median } & \multicolumn{2}{|c|}{ Above Median } \\
\hline Frac. Jewish Managers (1932) & -0.246 & -0.399 & $-0.606^{* * *}$ & $-0.439^{* * *}$ \\
\hline$\times$ Post 1933 & $(0.221)$ & $(0.243)$ & $(0.171)$ & $(0.166)$ \\
\hline Number of Observations & 5337 & 5337 & 7373 & 7373 \\
\hline Number of Firms & 291 & 291 & 364 & 364 \\
\hline $\mathrm{R}^{2}$ & 0.588 & 0.625 & 0.558 & 0.631 \\
\hline Firm FE & Yes & Yes & Yes & Yes \\
\hline Time FE & Yes & Yes & Yes & Yes \\
\hline All Controls & & Yes & & Yes \\
\hline
\end{tabular}

Notes: The dependent variable is the natural logarithm of the stock price. Stock prices are averaged in a plus-minus 10-day window around January 10th and July 10th of each year. The main explanatory variable measures the fraction of Jewish managers in 1932, interacted with an indicator for the months after January 1933. We identify an industry's dependence on managers by calculating the share of middle- and upper-level managers in an industry out of all employees, using data from the 1933 census. In columns 1 and 2, the sample contains firms in industries below the median. In columns 3 and 4, the sample contains firms in industries above the median. The control variables are identical to Table 4 . The data include the months January and July for the years from 1929 to 1943. Standard errors are clustered at the firm level. Significance levels: $* * * \mathrm{p}<0.01, * * \mathrm{p}<0.05$, and $* \mathrm{p}<0.1$. 
Table A.12: Managers in Chief And Regular Positions

\begin{tabular}{lcccccc}
\hline & $(1)$ & $(2)$ & $(3)$ & $(4)$ & $(5)$ & $(6)$ \\
Dep. Variable: $\log$ (Stock Price) & & & & & & \\
\hline Frac. Jewish Managers in Chief Executive & $-0.297^{* * *}$ & $-0.312^{* * *}$ & & & $-0.231^{*}$ & $-0.252^{* *}$ \\
Positions (1932) $\times$ Post 1933 & $(0.110)$ & $(0.104)$ & & & $(0.123)$ & $(0.115)$ \\
Frac. Jewish Managers in Regular & & & $-0.292^{* *}$ & $-0.290^{* *}$ & -0.208 & -0.204 \\
Positions (1932) × Post 1933 & & & $(0.125)$ & $(0.126)$ & $(0.138)$ & $(0.137)$ \\
& & & & & & \\
Firm FE & Yes & Yes & Yes & Yes & Yes & Yes \\
Time FE & Yes & Yes & Yes & Yes & Yes & Yes \\
All Controls & & Yes & & Yes & & Yes \\
& & & & & & \\
Number of Observations & 12710 & 12710 & 12710 & 12710 & 12710 & 12710 \\
Number of Firms & 655 & 655 & 655 & 655 & 655 & 655 \\
$\mathrm{R}^{2}$ & 0.565 & 0.621 & 0.564 & 0.620 & 0.566 & 0.622 \\
\hline
\end{tabular}

Notes: The dependent variable is the natural logarithm of the stock price. Stock prices are averaged in a plus-minus 10-day window around January 10th and July 10th of each year. We define managers in chief positions to be the top hierarchical level of the executive board and the chairmen of the supervisory board (i.e., managers performing functions akin to a modern $\mathrm{CEO}$ ). The remaining board members are regular managers. The first main explanatory variable measures the fraction of Jewish managers in chief positions in 1932, interacted with an indicator for the months after January 1933. The second main explanatory variable measures the fraction of Jewish managers in regular positions in 1932, interacted with an indicator for the months after January 1933. The control variables are identical to Table 4 . The data include the months January and July for the years from 1929 to 1943. Standard errors are clustered at the firm level. Significance levels: $* * * \mathrm{p}<0.01, * * \mathrm{p}<0.05$, and $* \mathrm{p}<0.1$. 


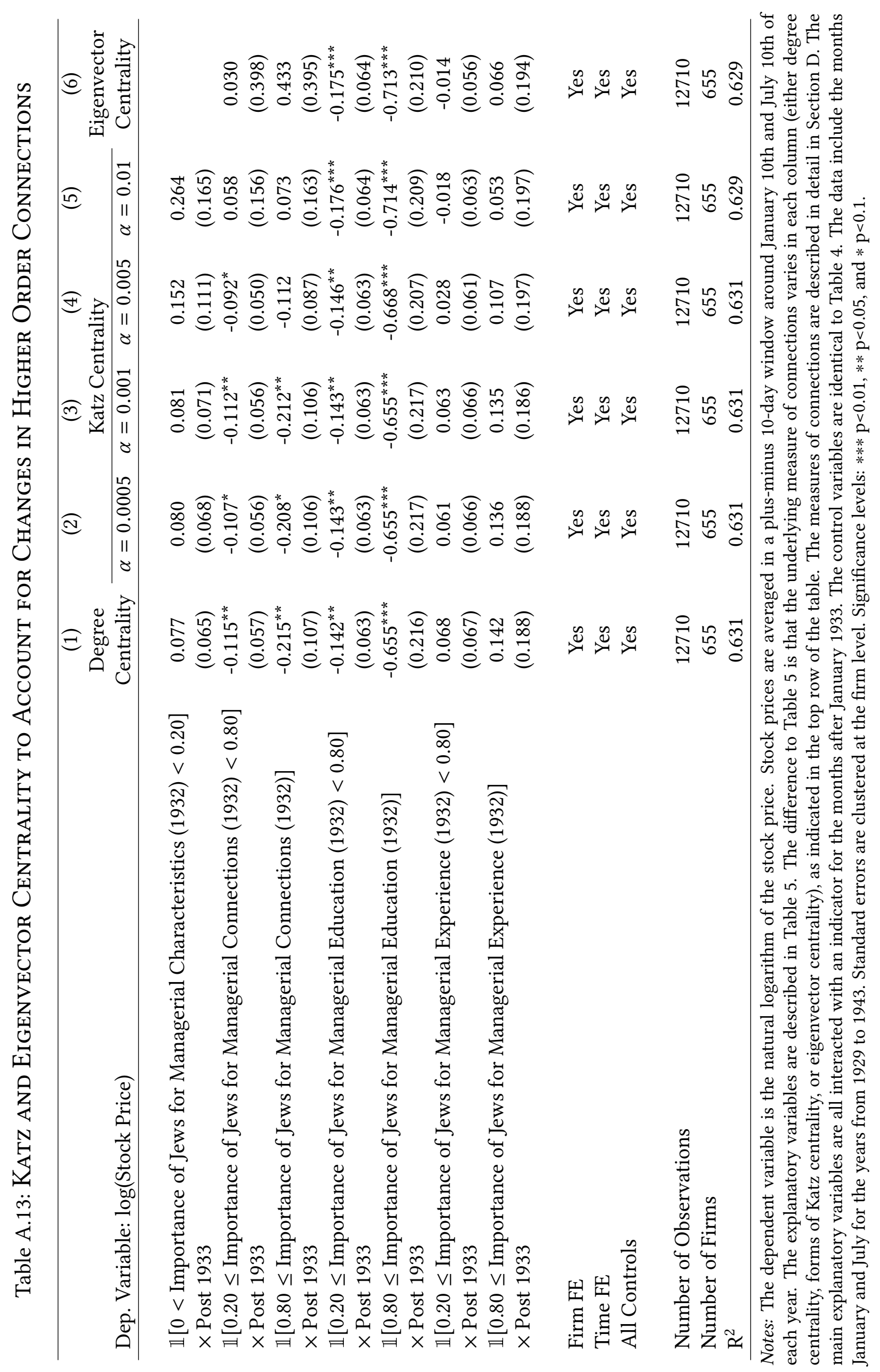


Table A.14: Connections to BAnks And Non-BAnks

\begin{tabular}{|c|c|c|c|c|c|c|}
\hline \multirow[b]{2}{*}{ Dep. Variable: $\log$ (Stock Price) } & (1) & (2) & (3) & (4) & (5) & (6) \\
\hline & \multicolumn{2}{|c|}{ All Connections } & \multicolumn{2}{|c|}{ Connections to Banks } & \multicolumn{2}{|c|}{ Connections to Non-Banks } \\
\hline $\mathbb{1}[0<$ Importance of Jews for Managerial Connections $(1932)<0.20]$ & -0.034 & -0.003 & -0.075 & -0.077 & -0.046 & -0.021 \\
\hline$\times$ Post 1933 & $(0.058)$ & $(0.059)$ & $(0.054)$ & $(0.054)$ & $(0.058)$ & $(0.059)$ \\
\hline $\mathbb{1}[0.20 \leq$ Importance of Jews for Managerial Connections $(1932)<0.80]$ & $-0.179^{* * *}$ & $-0.164^{* * *}$ & $-0.189^{* * *}$ & $-0.152^{* * *}$ & $-0.186^{* * *}$ & $-0.167^{* * *}$ \\
\hline$\times$ Post 1933 & $(0.048)$ & $(0.046)$ & $(0.053)$ & $(0.050)$ & $(0.048)$ & $(0.046)$ \\
\hline $\mathbb{1}[0.80 \leq$ Importance of Jews for Managerial Connections (1932)] & $-0.250^{* *}$ & $-0.295^{* * *}$ & $-0.169^{* *}$ & $-0.184^{* * *}$ & -0.141 & $-0.209^{* *}$ \\
\hline$\times$ Post 1933 & $(0.103)$ & $(0.098)$ & $(0.069)$ & $(0.065)$ & $(0.101)$ & $(0.106)$ \\
\hline Firm FE & Yes & Yes & Yes & Yes & Yes & Yes \\
\hline Time FE & Yes & Yes & Yes & Yes & Yes & Yes \\
\hline All Controls & & Yes & & Yes & & Yes \\
\hline Number of Observations & 12710 & 12710 & 12710 & 12710 & 12710 & 12710 \\
\hline Number of Firms & 655 & 655 & 655 & 655 & 655 & 655 \\
\hline $\mathrm{R}^{2}$ & 0.568 & 0.625 & 0.567 & 0.622 & 0.568 & 0.624 \\
\hline
\end{tabular}

Notes: The dependent variable is the natural logarithm of the stock price. Stock prices are averaged in a plus-minus 10 -day window around January 10th and July 10th of each year. The main explanatory variables are indicators for whether Jewish managers were responsible for: 1) less than 20 percent, 2) 20 percent to less than 80 percent, and 3) more than 80 percent of managerial connections. In columns 1 and 2, connections refer to connections to all firms. In columns 3 and 4 , connections refer only to connections to banks. In columns 5 and 6, connections refer only to connections to non-banks. For firms without Jewish managers in 1932, all of the reported indicator variables in all columns are zero. The main explanatory variables are all interacted with an indicator for the months after January 1933. The control variables are identical to Table 4. The data include the months January and July for the years from 1929 to 1943. Standard errors are clustered at the firm level. Significance levels: $* * * \mathrm{p}<0.01, * * \mathrm{p}<0.05$, and $* \mathrm{p}<0.1$.

\section{Table A.15: Region-Sector Cells With Few Lower-Ranked Jewish Employees}

\begin{tabular}{lcccccc}
\hline & $(1)$ & $(2)$ & $(3)$ & $(4)$ & $(5)$ & $(6)$ \\
& \multicolumn{5}{c}{ Below 25th Percentile of Jewish Employees: } \\
\cline { 2 - 7 } Dep. Variable: $\log$ (Stock Price) & $\begin{array}{c}\text { Blue Collar } \\
\text { Workers }\end{array}$ & $\begin{array}{c}\text { Lower-Ranked White } \\
\text { Collar Employees }\end{array}$ & Both Categories \\
\cline { 2 - 7 } & & & & & & \\
& & & & & \\
Frac. Jewish Managers (1932) & $-0.776^{* *}$ & $-0.689^{*}$ & $-0.750^{* *}$ & $-0.758^{* *}$ & $-0.857^{* *}$ & $-0.860^{* *}$ \\
$\times$ Post 1933 & $(0.338)$ & $(0.370)$ & $(0.329)$ & $(0.365)$ & $(0.367)$ & $(0.416)$ \\
& & & & & & \\
Firm FE & Yes & Yes & Yes & Yes & Yes & Yes \\
Time FE & Yes & Yes & Yes & Yes & Yes & Yes \\
All Controls & & Yes & & Yes & & Yes \\
& & & & & & \\
Number of Observations & 2824 & 2824 & 2888 & 2888 & 2342 & 2342 \\
Number of Firms & 165 & 165 & 165 & 165 & 136 & 136 \\
$\mathrm{R}^{2}$ & 0.569 & 0.662 & 0.588 & 0.667 & 0.578 & 0.666 \\
\hline
\end{tabular}

Notes: The dependent variable is the natural logarithm of the stock price. Stock prices are averaged in a plus-minus 10-day window around January 10th and July 10th of each year. The main explanatory variable measures the fraction of Jewish managers in 1932, interacted with an indicator for the months after January 1933. In columns 1 and 2, we only include firms in regions-sector cells below the 25th percentile among blue collar workers. In columns 3 and 4, we only include firms in regions-sector cells below the 25th percentile among lower-ranked white collar employees. In columns 5 and 6 , we only include firms in regions-sector cells below the 25th percentile among both blue collar workers and lower-ranked white collar employees. The data for the lower-ranked employees are from the $1933 \mathrm{German}$ census. The control variables are identical to Table 4. The data include the months January and July for the years from 1929 to 1943. Standard errors are clustered at the firm level. Significance levels: $* * * \mathrm{p}<0.01, * * \mathrm{p}<0.05$, and $* \mathrm{p}<0.1$. 


\section{Table A.16: Firms Without Large Jewish Shareholders}

\begin{tabular}{lcc}
\hline Dep. Variable: $\log$ (Stock Price) & $(1)$ & $(2)$ \\
\hline $\begin{array}{lcc}\text { Frac. Jewish Managers (1932) } \\
\times \text { Post 1933 }\end{array}$ & $-0.480^{* * *}$ & $-0.489^{* * *}$ \\
& $(0.156)$ & $(0.157)$ \\
Firm FE & Yes & Yes \\
Time FE & Yes & Yes \\
All Controls & & Yes \\
& & \\
Number of Observations & 11329 & 11329 \\
Number of Firms & 589 & 589 \\
$\mathrm{R}^{2}$ & 0.560 & 0.621 \\
\hline
\end{tabular}

Notes: The dependent variable is the natural logarithm of the stock price. Stock prices are averaged in a plus-minus 10-day window around January 10th and July 10th of each year. The main explanatory variable measures the fraction of Jewish managers in 1932, interacted with an indicator for the months after January 1933. We drop firms from the sample where a Jewish individual or a Jewish firm (for example, a Jewish private bank) was a large shareholder. The control variables are identical to Table 4. The data include the months January and July for the years from 1929 to 1943. Standard errors are clustered at the firm level. Significance levels: $* * * \mathrm{p}<0.01, * * \mathrm{p}<0.05$, and $* \mathrm{p}<0.1$.

Table A.17: Testing for SpILlover Effects

\begin{tabular}{lcccccc}
\hline & $(1)$ & $(2)$ & $(3)$ & $(4)$ & $(5)$ & $(6)$ \\
Dep. Variable: $\log$ (Stock Price) & & & & & & \\
\hline & & & & & & \\
Frac. Jewish Managers (1932) & $-0.463^{* * *}$ & $-0.471^{* * *}$ & $-0.430^{* * *}$ & $-0.427^{* * *}$ & $-0.426^{* * *}$ & $-0.421^{* * *}$ \\
$\times$ Post 1933 & $(0.138)$ & $(0.135)$ & $(0.144)$ & $(0.141)$ & $(0.145)$ & $(0.142)$ \\
Avg. Frac. Jewish Managers (Industry) & -0.108 & -0.180 & & & -0.100 & -0.170 \\
$\quad \times$ Post 1933 & $(0.256)$ & $(0.254)$ & & & $(0.254)$ & $(0.252)$ \\
Avg. Frac. Jewish Managers (Region) & & & -0.283 & -0.386 & -0.278 & -0.380 \\
$\quad \times$ Post 1933 & & & $(0.359)$ & $(0.348)$ & $(0.358)$ & $(0.347)$ \\
& & & & & & \\
Firm FE & Yes & Yes & Yes & Yes & Yes & Yes \\
Time FE & Yes & Yes & Yes & Yes & Yes & Yes \\
Controls & & Yes & & Yes & & Yes \\
& & & & & & \\
Number of Observations & 12710 & 12710 & 12710 & 12710 & 12710 & 12710 \\
Number of Firms & 655 & 655 & 655 & 655 & 655 & 655 \\
$\mathrm{R}^{2}$ & 0.566 & 0.582 & 0.566 & 0.582 & 0.566 & 0.582 \\
\hline
\end{tabular}

Notes: The dependent variable is the natural logarithm of the stock price. Stock prices are averaged in a plus-minus 10day window around January 10th and July 10th of each year. The first main explanatory variable measures the fraction of Jewish managers in 1932 at firm $i$. The second main explanatory variable measures the (weighted) average fraction of Jewish managers in 1932 in all other firms in the same industry. We use the industry classification with 43 categories (see Appendix Table A.6). Results are similar if we use the classification with 10 categories. The third main explanatory variable measures the (weighted) average fraction of Jewish managers in 1932 in all other firms in the same region. The three main explanatory variables are interacted with an indicator for the months after January 1933. We weight firms by nominal capital to calculate the average fraction of Jewish managers in all other firms in the same industry or region. For this weighting, we winsorize nominal capital at the 99.5th percentile, to ensure the three largest firms do not bias the average values excessively. The results are similar when we include unweighted measures of the average fraction of Jewish managers in the same industry or region in the regressions. The control variables are identical to Table 4. The data include the months January and July for the years from 1929 to 1943. Standard errors are clustered at the firm level. Significance levels: $* * * \mathrm{p}<0.01, * * \mathrm{p}<0.05$, and $* \mathrm{p}<0.1$. 


\section{Table A.18: The Effect on Dividends and Return on Assets in Firms Favored by THE NAZIS}

\begin{tabular}{lcc}
\hline & $(1)$ & $(2)$ \\
Dep. Variable: & Dividends & Return on Assets \\
\hline Frac. Jewish Managers (1932) & $-3.227^{*}$ & $-0.433^{* * *}$ \\
$\times$ Post 1933 & $(1.814)$ & $(0.107)$ \\
& & \\
Firm FE & Yes & Yes \\
Time FE & Yes & Yes \\
All Controls & Yes & Yes \\
& & \\
Number of Observations & 2019 & 167 \\
Number of Firms & 171 & 96 \\
$\mathrm{R}^{2}$ & 0.408 & 0.816 \\
\hline
\end{tabular}

Notes: The dependent variable in column 1 is the annual dividend payment, measured as a percentage of the nominal stock value. The data in column 1 include the years 1929 to 1943 . The dependent variable in column 2 is the return on assets, measured as the ratio of profits before interest payments and taxes to total assets. The data in columns 2 include the years 1931, 1936, and 1940. The main explanatory variable measures the fraction of Jewish managers in 1932, interacted with an indicator for the months after January 1933. The sample of favored firms contains firms with connections to the Nazi Party and firms that received forced labor workers from the Nazi government, excluding firms historically perceived as Jewish. The control variables are identical to Table 4 . Standard errors are clustered at the firm level. Significance levels: $* * * \mathrm{p}<0.01$, $* * \mathrm{p}<0.05$, and $* \mathrm{p}<0.1$.

\section{Table A.19: The Effect on Dividends and Return on Assets: Jewish Managers Vs. Firms Perceived As Jewish}

\begin{tabular}{|c|c|c|}
\hline & (1) & (2) \\
\hline Dep. Variable: & Dividends & Return on Assets \\
\hline Jewish Firm & -0.710 & -0.026 \\
\hline$\times$ Post 1935 & $(0.520)$ & $(0.045)$ \\
\hline Frac. Jewish Managers (1932) & $-1.444^{*}$ & $-0.172^{*}$ \\
\hline$\times$ Post 1933 & $(0.777)$ & $(0.090)$ \\
\hline Firm FE & Yes & Yes \\
\hline Time FE & Yes & Yes \\
\hline All Controls & Yes & Yes \\
\hline Number of Observations & 7379 & 492 \\
\hline Number of Firms & 655 & 289 \\
\hline $\mathrm{R}^{2}$ & 0.241 & 0.561 \\
\hline
\end{tabular}

Notes: The dependent variable in column 1 is the annual dividend payment, measured as a percentage of the nominal stock value. The data in column 1 include the years 1929 to 1943 . The dependent variable in column 2 is the return on assets, measured as the ratio of profits before interest payments and taxes to total assets. The data in columns 2 include the years 1931, 1936, and 1940. The first main explanatory variable is an indicator for firms historically perceived as Jewish, interacted with an indicator for the months after January 1935. The second main explanatory variable measures the fraction of Jewish managers in 1932, interacted with an indicator for the months after January 1933. The control variables are identical to Table 4. Standard errors are clustered at the firm level. Significance levels: $* * * \mathrm{p}<0.01, * * \mathrm{p}<0.05$, and $* \mathrm{p}<0.1$. 


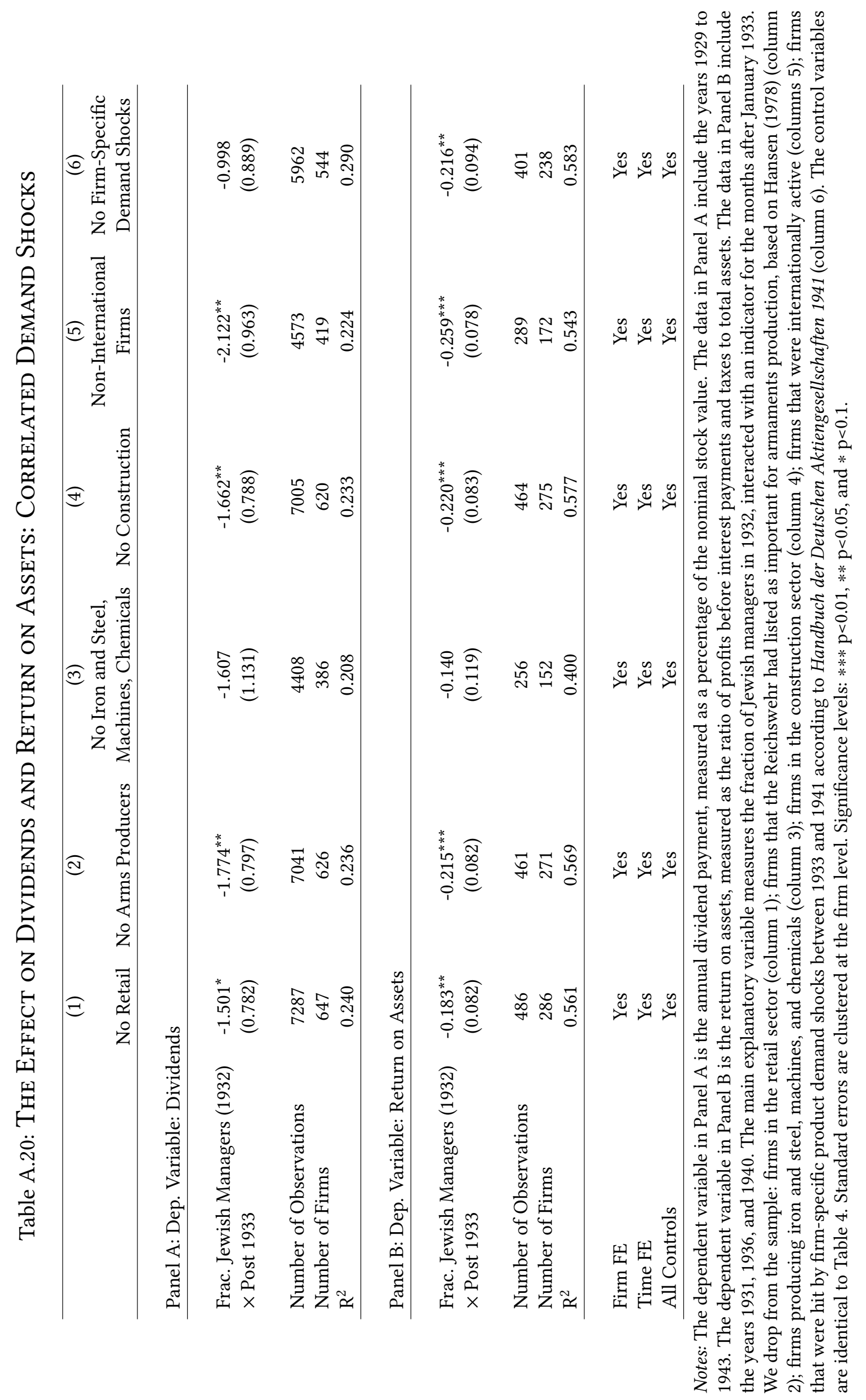


Table A.21: Robustness to VArious Controls for Firm Size

\begin{tabular}{|c|c|c|c|c|c|c|}
\hline \multirow[t]{3}{*}{ Dep. Variable: $\log$ (Stock Price) } & $(1)$ & $(2)$ & (3) & (4) & (5) & (6) \\
\hline & \multirow{2}{*}{\multicolumn{3}{|c|}{ Full Sample }} & Without & \multicolumn{2}{|c|}{ Firm Size } \\
\hline & & & & Conglomerates & $\leq$ Median & $>$ Median \\
\hline \multicolumn{7}{|c|}{ Panel A: Measure of Firm Size: Nominal Capital } \\
\hline $\begin{array}{l}\text { Frac. Jewish Managers (1932) } \\
\times \text { Post } 1933\end{array}$ & $\begin{array}{c}-0.464^{* * *} \\
(0.138)\end{array}$ & $\begin{array}{c}-0.406^{* * *} \\
(0.136)\end{array}$ & $\begin{array}{c}-0.406^{* * *} \\
(0.135)\end{array}$ & $\begin{array}{c}-0.439^{* * *} \\
(0.134)\end{array}$ & $\begin{array}{l}-0.596^{* *} \\
(0.266)\end{array}$ & $\begin{array}{c}-0.474^{* * *} \\
(0.161)\end{array}$ \\
\hline Number of Observations & 12710 & 12710 & 12710 & 12655 & 5170 & 7540 \\
\hline Number of Firms & 655 & 655 & 655 & 653 & 335 & 320 \\
\hline $\mathrm{R}^{2}$ & 0.622 & 0.628 & 0.635 & 0.626 & 0.660 & 0.630 \\
\hline \multicolumn{7}{|c|}{ Panel B: Measure of Firm Size: Total Number of Managers } \\
\hline $\begin{array}{l}\text { Frac. Jewish Managers (1932) } \\
\times \text { Post } 1933\end{array}$ & $\begin{array}{c}-0.416^{* * *} \\
(0.135)\end{array}$ & $\begin{array}{c}-0.381^{* * *} \\
(0.136)\end{array}$ & $\begin{array}{c}-0.368^{* * *} \\
(0.137)\end{array}$ & $\begin{array}{c}-0.401^{* * *} \\
(0.136)\end{array}$ & $\begin{array}{c}-0.493^{* *} \\
(0.215)\end{array}$ & $\begin{array}{c}-0.433^{* *} \\
(0.169)\end{array}$ \\
\hline Number of Observations & 12710 & 12710 & 12710 & 12655 & 5950 & 6760 \\
\hline Number of Firms & 655 & 655 & 655 & 653 & 345 & 310 \\
\hline $\mathrm{R}^{2}$ & 0.624 & 0.624 & 0.634 & 0.625 & 0.657 & 0.623 \\
\hline
\end{tabular}

Panel C: Measure of Firm Size: Both Nominal Capital and Total Number of Managers

\begin{tabular}{|c|c|c|c|c|c|c|}
\hline $\begin{array}{l}\text { Frac. Jewish Managers (1932) } \\
\times \text { Post } 1933\end{array}$ & $\begin{array}{c}-0.417^{* * *} \\
(0.135)\end{array}$ & $\begin{array}{c}-0.375^{* * *} \\
(0.135)\end{array}$ & $\begin{array}{c}-0.362^{* * *} \\
(0.133)\end{array}$ & $\begin{array}{c}-0.403^{* * *} \\
(0.135)\end{array}$ & & \\
\hline Number of Observations & 12710 & 12710 & 12710 & 12655 & & \\
\hline Number of Firms & 655 & 655 & 655 & 653 & & \\
\hline $\mathrm{R}^{2}$ & 0.625 & 0.629 & 0.647 & 0.627 & & \\
\hline Firm FE & Yes & Yes & Yes & Yes & Yes & Yes \\
\hline Time FE & Yes & Yes & Yes & Yes & Yes & Yes \\
\hline All Other Controls & Yes & Yes & Yes & Yes & Yes & Yes \\
\hline Firm Size & Yes & & & Yes & Yes & Yes \\
\hline Log of Firm Size & & Yes & & & & \\
\hline Deciles of Firm Size & & & Yes & & & \\
\hline
\end{tabular}

Notes: The dependent variable is the natural logarithm of the stock price. Stock prices are averaged in a plus-minus 10-day window around January 10th and July 10th of each year. The main explanatory variable measures the fraction of Jewish managers in 1932, interacted with an indicator for the months after January 1933. We use the full sample in columns 1 to 3. In column 4 , we drop conglomerates. In column 5 , the sample contains only firms below the median for the respective firm size measure (panel A: nominal capital, panel B: total number of managers). In column 6, the sample contains only firms above the median for the respective firm size measure. Column 1 and columns 4 to 6 control for the level of the respective firm size measure, column 2 for natural logarithm of the firm size measure, and column 3 for deciles of the firm size measure. In addition, all specifications include control variables identical to Table 4 . The data include the months January and July for the years from 1929 to 1943. Standard errors are clustered at the firm level. Significance levels: $* * * \mathrm{p}<0.01, * * \mathrm{p}<0.05$, and $* \mathrm{p}<0.1$. 


\section{Table A.22: Firms That Are Regularly Traded or Never Delisted}

\begin{tabular}{lcccccccc}
\hline & $(1)$ & $(2)$ & $(3)$ & $(4)$ & $(5)$ & $(6)$ & $(7)$ & $(8)$ \\
Dep. Variable: $\log$ (Stock Price) & $\geq 15$ Stock Prices & $\geq 25$ Stock Prices & 30 Stock Prices & Never Delisted \\
\hline & & & & & & & & \\
Frac. Jewish Managers (1932) & $-0.421^{* * *}$ & $-0.445^{* * *}$ & $-0.396^{* *}$ & $-0.420^{* * *}$ & $-0.700^{* * *}$ & $-0.720^{* * *}$ & $-0.432^{* * *}$ & $-0.482^{* * *}$ \\
$\times$ Post 1933 & $(0.146)$ & $(0.145)$ & $(0.157)$ & $(0.154)$ & $(0.235)$ & $(0.233)$ & $(0.158)$ & $(0.155)$ \\
& & & & & & & & \\
Firm FE & Yes & Yes & Yes & Yes & Yes & Yes & Yes & Yes \\
Time FE & Yes & Yes & Yes & Yes & Yes & Yes & Yes & Yes \\
All Controls & & Yes & & Yes & & Yes & & Yes \\
& & & & & & & & \\
Number of Observations & 10645 & 10645 & 8755 & 8755 & 3690 & 3690 & 9907 & 9907 \\
Number of Firms & 401 & 401 & 306 & 306 & 123 & 123 & 371 & 371 \\
$\mathrm{R}^{2}$ & 0.574 & 0.639 & 0.597 & 0.666 & 0.570 & 0.677 & 0.583 & 0.647 \\
\hline
\end{tabular}

Notes: We include firms that were traded on at least 15 Januarys or Julys between January 1929 and July 1943 in columns 1 and 2. We include firms that were traded on at least 25 Januarys or Julys in columns 3 and 4 . We include firms that were traded on all 30 Januarys or Julys in columns 5 and 6. We include only firms that were never delisted in columns 7 and 8 . The dependent variable is the natural logarithm of the stock price. Stock prices are averaged in a plus-minus 10-day window around January 10th and July 10th of each year. The main explanatory variable measures the fraction of Jewish managers in 1932, interacted with an indicator for the months after January 1933. The control variables are identical to Table 4 . The data include the months January and July for the years from 1929 to 1943. Standard errors are clustered at the firm level. Significance levels: $* * * \mathrm{p}<0.01, * * \mathrm{p}<0.05$, and $* \mathrm{p}<0.1$.

\section{Table A.23: The Effect on Firm Delisting And Firm Exit}

\begin{tabular}{|c|c|c|c|c|c|c|}
\hline \multirow{2}{*}{$\begin{array}{l}\text { Dep. Variable: } \\
\text { Frac. Jewish Managers (1932) }\end{array}$} & $\begin{array}{l}\text { (1) } \\
\text { Linear } \\
\text { Deli }\end{array}$ & $\begin{array}{l}\text { (2) } \\
\text { bility Model } \\
\text { Indicator }\end{array}$ & $\begin{array}{l}(3) \\
\text { Extend } \\
\text { D }\end{array}$ & $\begin{array}{l}\text { (4) } \\
\text { Hazard Model } \\
\text { Indicator }\end{array}$ & \multicolumn{2}{|c|}{$\begin{array}{c}\text { Linear Probability Model } \\
\text { Firm Exit Indicator }\end{array}$} \\
\hline & $\begin{array}{l}-0.018 \\
(0.128)\end{array}$ & $\begin{array}{l}-0.038 \\
(0.130)\end{array}$ & & & $\begin{array}{c}0.084 \\
(0.074)\end{array}$ & $\begin{array}{c}0.059 \\
(0.072)\end{array}$ \\
\hline $\begin{array}{l}\text { Frac. Jewish Managers (1932) } \\
\times \text { Post } 1933\end{array}$ & & & $\begin{array}{l}-0.415 \\
(0.448)\end{array}$ & $\begin{array}{l}-0.280 \\
(0.459)\end{array}$ & & \\
\hline All Controls & & Yes & & Yes & & Yes \\
\hline $\begin{array}{l}\text { Number of Firms } \\
\mathrm{R}^{2}\end{array}$ & $\begin{array}{c}655 \\
0.000\end{array}$ & $\begin{array}{c}655 \\
0.051\end{array}$ & 655 & 655 & $\begin{array}{c}655 \\
0.003\end{array}$ & $\begin{array}{c}655 \\
0.026\end{array}$ \\
\hline
\end{tabular}

Notes: Columns 1 and 2 report the results of a cross-sectional, linear probability model. The dependent variable in columns 1 and 2 is an indicator that is equal to 1 if the firm was delisted from the Berlin Stock Exchange after January 1933. The main explanatory variable measures the fraction of Jewish managers in 1932. Columns 3 and 4 report the results of an extended Cox hazard model, with time-varying coefficients. The data include two periods, before and after January 1933. The dependent variable in columns 3 and 4 is the natural logarithm of the relative hazard of being delisted in the relevant period. The main explanatory variable measures the fraction of Jewish managers in 1932, interacted with an indicator for the period after January 1933. Columns 5 and 6 report the results of a cross-sectional, linear probability model. The dependent variable in columns 5 and 6 is an indicator for firm exit. The main explanatory variable measures the fraction of Jewish managers in 1932. In columns 1-2 and 5-6, the control variables include: an indicator for any connections to the Nazi Party, an indicator for whether the firm published its 1932 financial statement in January, firm age in 1932, firm nominal capital in 1932, and industry fixed effects. In columns 3-4, the control variables are as above, but all are interacted with fixed effects for the periods before and after January 1933. Standard errors are clustered at the firm level. Significance levels: $* * * \mathrm{p}<0.01$, $* * \mathrm{p}<0.05$, and $* \mathrm{p}<0.1$. 


\section{B Online Appendix: Data Construction}

\section{B.1 Information on Managers}

In 1932, a total of 784 stocks were listed on the Berlin Stock Exchange. Handbuch der deutschen Aktiengesellschaften reports only information on German firms, so we exclude 25 stocks of foreign firms. We also exclude eight stocks for which the Handbuch does not report board members and two stocks that were never traded in our sample period. A total of 41 firms issued multiple stocks, so we choose the most frequently traded stock for these firms. Of the remaining 708 firms, we exclude 16 stocks of firms in liquidation in January 1933 and 37 stocks of firms that merged with other firms during our sample period and where the merger resulted in a change of the stock name reported in the Monatskursblatt.

The data on senior managers of all firms listed on the Berlin Stock exchange in 1932 are from four editions of the Handbuch der deutschen Aktiengesellschaften (1928, 1932, 1933, and 1939), which is a compilation of annual reports of all joint stock firms in Germany (see Figure B.1 for a sample page). Until 1933, the Handbuch included amendments, so that the list of senior managers reflects the status at the end of the respective years (1928, 1932, and 1933). In 1939, the Handbuch did not publish amendments so that the list of senior managers reflects the status at the time of the publication of the annual report. We therefore refer to the relevant years as 1928, 1932, 1933, and 1938. 
Figure B.1: Example Page from Handbuch der deutschen Aktiengesellschaften 1932

\section{Bayerische Motoren-Werke, Akt.-Ges.}

in München, Lerehenauer Strasse 76.

Gegrïndet: 19./2., 20./2. u. 2./3. 1916; eingetr. 8./3. 1916 unter der Firma Bayer. Flugzeugwerke (bis 4./7. 1922). Zweigniederl, in Eisenach.

Zweck: Herstell. u. gewerbsmåssiger Vertrieb von Motoren u. allen damit ausgestatteten Fahrzeugen, deren Zubehör, sowie allen Erzeugnissen der Maschinen-, Metall- u. Holzindustrie. Zur Zeit befasst sich die Ges. mit der Herstellung von Flugzeugmotoren sowie von Motorrädern u. Automobilen.

Entwicklung: Die Ges, erwarb 1922 die gesamten Einricht., Patente u. Konstruktionen sowie alle aus dem Motorenbau stammeniden Rechte u. Pflichten, ferner auch den Namen der damaligen Firma Bayerische Motoren Werke, A.G., den sie seit dieser Zeit führt. Die

Kurs: In Berlin: Ende 1926-1930: 180, 200.75, 232, 81, 54\%; 1931 (30./6.): 48.75\%. In München Ende 1926-1930: 181, 198, 232.50, 81, 52.50\%: 1931 (30./6.): $46 \%$. Zulassung von RM. 5000000 Akt. in Berlin u. München Juni 1926 genehmigt. Zulassung von RM. 5000000 Em. v. April 1927 im Juni 1927 in Berlin u. München. Zulassung von RM. 6000000 Akt. (Em. v. Juli 1928) im Sept. 1928 in Berlin u. München. Sämtl. Aktien sind zugelassen. Dividenden: $1924-1931$ : $10,10,12,14,14,7,0,0 \%$.

Vorstand: Dipl.-Ing. F. J. Popp, Max Friz, Franz Klebe, Fritz Klopfer, München. Prokuristen: Dr. Franz Brenner, München; Ingobert Starke, München; L. C. Grass, Eisenach; Curt Ebersbach, Eisenach; Albert Kandt, Eisenach.

Aufsichtsrat: Vors. Bank-Dir. Dr. E. G. von Stauss: Stellv. Bankier Karl Hagen, Stellv. Dir. Max H. Sehmid, Louis Hagen jr., Bank-Dir. Dr. Wilhelm Kleemann, Berlin: Dir. Wilhelm Kissel, Stuttgart; Dipl.-Ing. Hans Noris, München; Justizrat Dr. h. c. Albert Pinner, Bankier Max von Wassermann, Berlin; Bankdir. Ludwig Weil, München; vom Betriebsrat: R. Vigier, F. Ifland.

Notes: The figure displays the entry for Bayerische Motoren-Werke (BMW) from the 1932 edition of the Handbuch der deutschen Aktiengesellschaften, pp 435-437.

\section{B.1.1 Harmonizing Manager Names}

We manually harmonize the spelling of thousands of manager names. This allows us to match managers across firms in the same volume of the Handbuch and/or across different volumes of the Handbuch. For example, "Philipp Heineken" is sometimes abbreviated as "Phil. Heineken" or "Ph. Heineken." The harmonization also allows us to match managers to sources on Jewish managers.

\section{B.1.2 Measuring Manager Characteristics}

\section{Tenure and Experience}

After harmonizing the spelling of manager names, we merge the list of all managers who were present 1932 to the list of managers who were present in 1928. This allows us to measure tenure and experience as senior managers since 1928.

\section{University Education}

We classify managers as managers with a university education if the Handbuch lists them with the following characteristics:

1. Professor title (Prof.)

2. PhD (Dr.), but not honorary doctorates 
3. Professions that require a university degree (for example, Diplomingeneur, Rechtsanwalt, Architekt, Chemiker)

4. Civil service positions that require a university degree (for example, Justizrat, Ministerialdirektor, Finanzrat)

Sometimes, the same manager reports a characteristic (for example, a $\mathrm{PhD}$ degree) in the annual report of one firm but does not report the characteristic in the annual report of another firm. If a characteristic is reported at least once for a manager in a certain volume of the Handbuch we classify the manager as holding that characteristic (for example, a university degree) for all firms in that year.

\section{Graduate Education and Field of Dissertation}

We classify managers as managers with graduate education as those who have a $\mathrm{PhD}(\mathrm{Dr}$.) degree using the information from the Handbuch der Deutschen Aktiengesellschaften. In addition we hand-collect the field of study (in particular STEM versus social sciences) for each manager with graduation education using the following steps:

1. We search for each manager with graduate education in https://www.worldcat.org/ and limit the search to "thesis/dissertations" published between 1880 and 1930. This search yields between 0 and 64 possible dissertation matches for each university educated manager.

2. We then conduct an extensive biographical search (using information in World Biographical Information System, see below, complemented by an extensive Google search) for each manager to uniquely assign the correct dissertation to each manager with graduate education. Using the title of the $\mathrm{PhD}$ dissertation we assign a field (for example, chemistry, law, and so on) to each dissertation (for example, Walter Dyckerhoff who was a senior manager at Portland-Zementwerke Dyckerhoff-Wicking A.G wrote a dissertation entitled "About the course of mineral formation when heating mixtures of lime, silica, and alumina." We classify this dissertation as a STEM dissertation.)

3. For managers where steps 1 and 2 do not yield a unique dissertation because a) no dissertation could be found on https://www.worldcat.org/ or b) because it is impossible to uniquely assign one of the dissertation, we conduct another biographical search to obtain the field of graduate education, using information in World Biographical Information System and Google searches.

4. For managers where steps 1 to 3 do not result in a field of graduate education, we use information from Handbuch der Deutschen Aktiengesellschaften to assign the field of graduate education. For instance, some managers list the exact $\mathrm{PhD}$ title which allows us to infer the 
field of the $\mathrm{PhD}$ (for example, Dr. jur. indicates that somebody has obtained a graduate degree in law). ${ }^{47}$

Overall, 1,181 managers holding 2,106 positions in 1932 had a graduate degree. Using our algorithm, we can assign a field of study to 870 managers, holding 1,667 positions. The regressions reported in Table 6 control for indicators representing the share of Jewish managers with a graduate degree for which we cannot assign a field of study.

\section{Number of Connections}

For each of the four years 1928, 1932, 1933, and 1938, we count the number of managerial connections to 4,378 German stock corporations. These corporations were listed in Berlin and/or had nominal capital of at least 500,000 RM. 7 firms listed in Berlin had nominal capital below 500,000 RM. The majority of German stock corporations were not listed on any stock market and rarely traded.

To measure connections, we harmonize the spelling of manager names across firms and consider additional information about each manager (for example, whether he holds a $\mathrm{PhD}$ degree or information on his place of residence) to identify unique managers. We consider connections to 4,387 firms with 41,522 senior manager positions in 1928, 4,378 firms with 39,054 senior manager positions in 1932, 4,074 firms with 34,816 senior manager positions in 1933, and 3,200 firms with 27,299 senior manager positions in 1938.

\section{B.1.3 Information on the Jewish Origin of Managers}

As described in the main text, we consult multiple sources to identify Jewish managers.

1. Münzel (2006)

Münzel (2006) analyses Jewish board members in the 300 largest joint stock firms. We extract all Jewish board members from his book.

2. Windolf (2011)

Windolf (2011) compiles a list of Jewish board members in German firms. We use this list to identify additional Jewish board members.

\section{Biographisches Handbuch der deutschsprachigen Emigration nach 1933}

The Biographisches Handbuch contains short biographies of Jewish business people who emigrated from Nazi Germany. We extract all individuals who are listed under the business heading.

4. Köhler (2008)

Studies private bankers of Jewish origin. This allows us to identify Jewish board members who were also private bankers.

\footnotetext{
${ }^{47}$ The results are robust to only using steps 1 to 3 for the field assignment of graduate degrees.
} 
For managers who did not appear in these sources, we conduct a manual search in:

\section{World Biographical Information System (WBIS)}

The database combines biographical information from various collections of biographies, for example Deutsches Biographisches Archiv (DBA) and Jüdisches Biographisches Archiv (JBA). We search the WBIS for all managers who did not appear in sources 1 to 4 to check whether they were of Jewish origin. Jews are identified if they appear in the Füdisches Biographisches Archiv (JBA), Ekkehard (1929), Lowenthal (1981), Tetzlaff (1982), Walk (2014), or if they list their religion as Jewish in any other source. The following example provides an overview of the procedure.

\section{Example World Biographical Information System (WBIS)}

The 1932 edition of the Handbuch der deutschen Aktiengesellschaften lists Alfred Zielenziger as manager of Deutsche Hypothekenbank AG and Schultheiss-Patzenhofer Brauerei AG. Since Zielenziger is not listed among the managers in sources 1 to 4 we follow a manual search through World Biographical Information System (WBIS). We find three entries in Deutsches Biographisches Archiv (DBA) and two entries in Jüdisches Biographisches Archiv (JBA). Figure B. 2 reports the respective entries from the DBA. The entries from JBA are identical to entries (b) and (c) from DBA and therefore not reported. We identify Alfred Zielenziger as Jewish because he appears in Lowenthal (1981) and Walk (2014), which are biographical sources on Jews in Germany.

Figure B.2: Example of Alfred Zielenziger
(a) Wenzel (1929)
(b) Lowenthal (1981)

ZIELENZIGER ALFRED, Bankicr; Inh. d. Fa. Altred Zielenziser \& Co., Banktetch, Produkterhandel, Bezliti W B, Taluberutr. 35 / BerlinCharlartenburk 7, Biemarckstr. 106 , Fribe Bunkesclatift, Herlin - Stelty. Yors d Getrejde-Kreditbank AG Berlin; Mlit d AR. d. Berlimer Daupfüle $A G$ ing d. Urion-Bauges. Berlin, Herz Difabriken AG. Bia 28 Vors, d. AR. d. Getreide-Ind. \& -Commission. AG. Berlin. Mitgh. d. I, U. HK. Berlin; Anssith-Mitglied d. Bezirksgr. Berlin d. Reichsverb. d. Deuzsth. Gros- u. Ubersechandels e. V.; Vors. d. Berline Börseavorst., Abr, Produktenbbrsc; 29 r. Stelly. d. Vork. d. Gesumtbarsenyorat. Vora. d. Vereina BerHiner Getreidehendler e. V Miryd d Landeseisenbuhnrats Berlin d. Deutsch. Reichsbahn; stelly. Mírgl. d. Reitlis-Ejsenbaborats. 一 Komkat.

\section{ZIELENZIGER, Alfred}

Geb. 1861 (Frankfurtroder); Kaufmann (Ggtreldehendel: Firmen S. \& M. Simon Singfried Elton \& Co., Barliner Getreide. bank], 1929-1933 Erster Vorsitzender der Berllner Produktenborse, Stelly. VorslIzerder des Gesamtvorstandes der Bertiпег Bōrso.

Lowenthal, Emst. G.: Juden in Preissen, 1981 (c) Walk (2014)

134. Walk, Joseph: Kurdbiographien zur Geschichte der Juden 1918-1945. HrSe, wom Lec Baecis Instítute, Jcrusialem. Mänchen, New Yoris, Loncon, Paris: Shaur 1988. XVII, $452 \mathrm{~S}$

Zielenziger, Alfred geh. 1861 FrankfurvOder, gest. ?, Kaufmant Inh. Fizma Sicgfried Elton Car; Berliner Getrejdebank; swit 1900 Mitgl, des Börsenvorst.; seir 1905 Mitgl. der lnd wsric- wid Handelskammer, Berlin: $1929-33$ Vors. der Berliner Produkteribörse; stellvertr. Vors des Gesantvorst. der Berliner Börsc.

BN: Kaznelsen, S. 735: Feder, S. 4.31; Lowenthal, Prenlien, S. 250 .

Deutscher Wirtschaf tsführer. Beatb. von Georg Wenzel. 1929 (363)

Notes: The figure displays the entries for Alfred Zielenziger from World Biographical Information System (WBIS) based on Wenzel (1929), Lowenthal (1981), and Walk (2014). 
Finally, we hand-check all managers who did not appear in sources 1-5 by conducting an internet search to find information on their ancestry.

6. Internet Search

For example, for managers based in Berlin, we look up füdisches Addressbuch für Großberlin, 1931 (available at: https://digital.zlb.de/viewer/resolver?urn=urn:nbn:de:kobv:109-1-2414417) and verify whether they can be matched by name and address with an entry in the address book. The following example provides an overview of the procedure.

\section{Example Internet Search}

The 1932 edition of the Handbuch der deutschen Aktiengesellschaften lists Dr. Felix Warschauer as manager of Hermann Meyer \& Co. AG. Since Dr. Warschauer is not listed among the managers in sources 1 to 4, we follow a manual search through WBIS. We find one entry in Deutsches Biographisches Archiv (DBA). The entry in Wenzel (1929) lists Dr. Warschauer with an address in Berlin (Berlin-Schöneberg, Bayerischer Platz 9, see Figure B.3), but does not contain information on his religion. The Berlin address allows us to check for an entry in the Füdisches Addressbuch für Großberlin, 1931 which lists addresses of Jews in Berlin. We find Dr. Felix Warschauer with the same address in the Füdisches Addressbuch für Großberlin, 1931 (see Figure B.3) and hence classify him as a Jew.

Figure B.3: Example of Dr. Felix Warschauer

(a) Wenzel (1929)

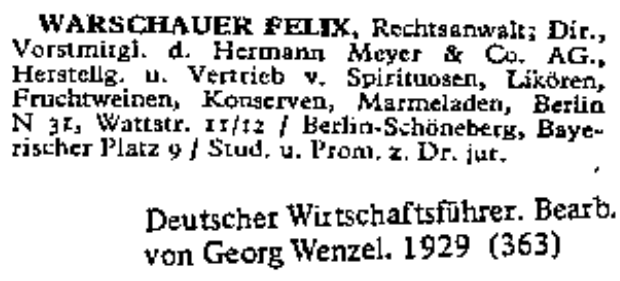

(b) Jüdisches Adressbuch für Großberlin, 1931

Warsehauer, Eugen, Sanitätsrat,
W 35 , Potsdamer Str. 118 c
Warsehauer, Dr. Felix, Sehöne-
berg, Bayerischer Platz 9
Warsehauer, Frieda, S 59 ,
Kottbusser Damm 63
Warsehauer, Dr. phil. Fritz, SW 61,
Belle-Alliance-Platz 3
Warsehauer, Georg, N 58 ,
Wolliner Str. 18/19
Warsehauer, Henriette, Charlotten-
burg 2, Schillerstr. 6

Notes: The left subfigure displays the entries for Dr. Felix Warschauer from World Biographical Information System (WBIS) based on Wenzel (1929). The right subfigure displays the entry for Dr. Felix Warschauer from Jüdisches Adressbuch für Großberlin, 1931, p. 420.

\section{B.2 Information on Firms}

\section{B.2.1 Stock Price Data}

We manually digitize all stock prices for January and July of each year between 1929 and 1943 from historical listings (called Börse und Wirtschaft, later Monatskursblatt Berliner Börse) of the 
Berlin Stock Exchange. Figure B.4 provides an example of page 21 from the January 1933 edition. Because of the German banking crisis in 1931/1932 the Berlin Stock Exchange was closed in January 1932. We therefore collect stock prices for April and October for 1932.

Figure B.4: Example Page from Börse und Wirtschaft, later Monatskursblatt Berliner Börse
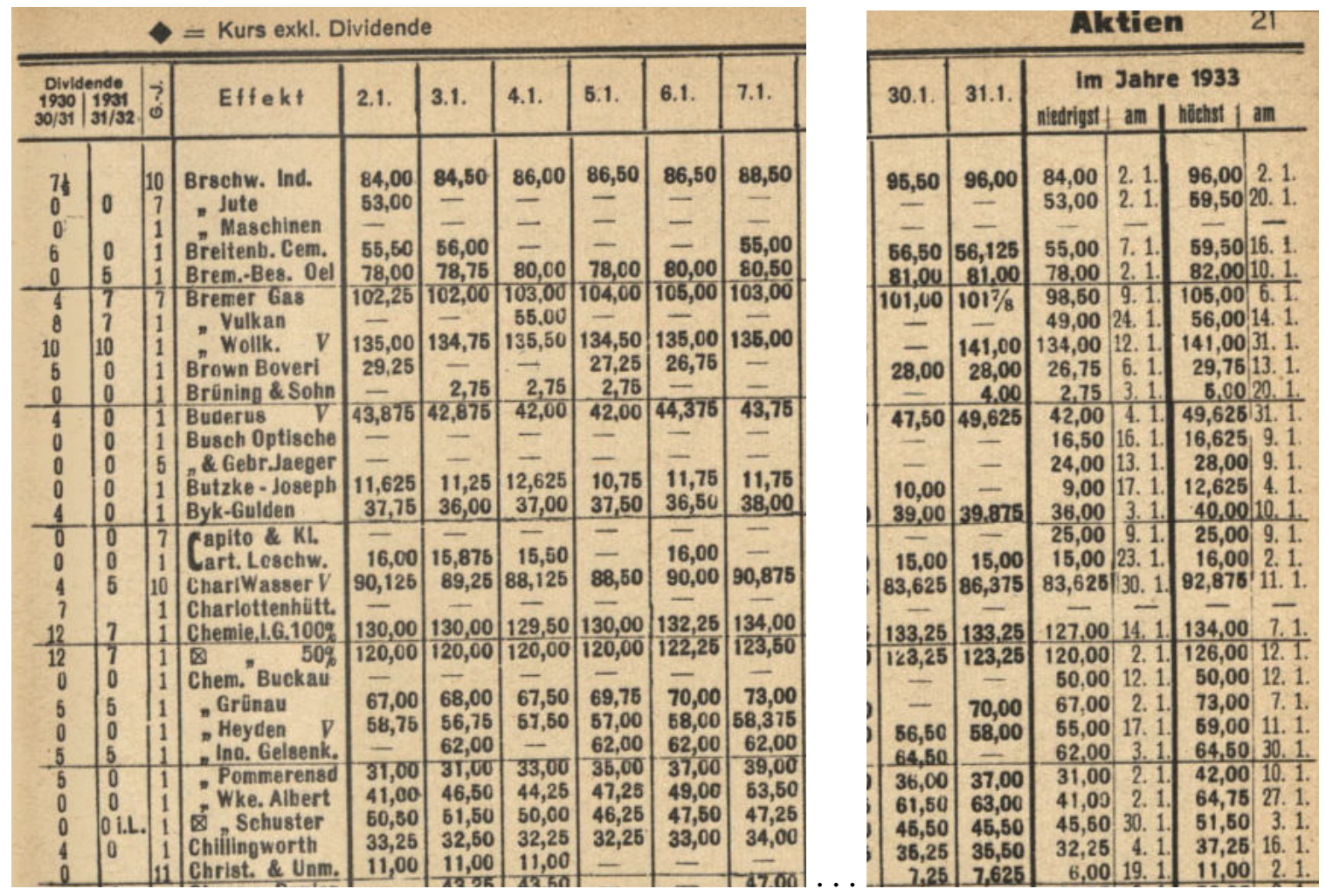

Notes: The figure displays the top left and top right of page 21 of the January 1933 edition of Börse und Wirtschaft, later Monatskursblatt Berliner Börse. The columns of the left panel report (from left to right) the dividend in 30/31, the dividend in 31/32, the reporting period, the stock name, and the stock prices of the trading days indicated as column titles. The columns of the top left panel (from left to right) report additional stock prices and the lowest (niedrigst) and highest (höchst) stock price and the respective dates in the calender year 1933.

Name Changes: We track stocks even if they change names (for example, Krauß \& Comp. changed its name to Lokomot. Krauß in July 1934). In most cases, the reported highest and lowest stock prices over the calendar year reveal that the stocks changed names. For example, in July 1934 Lokomot. Krauß reported a lowest stock price over the calendar year of 67 for January 19, 1934, which exactly matches the stock price of Krauß \& Comp. on that day. In addition, we verify all name changes by consulting the narrative information in the Handbuch der deutschen Aktiengesellschaften.

Stock Consolidations: Between 1929 and 1943, the stocks of some firms were consolidated. For example, Dresdner Bank stocks were consolidated on August 4, 1932 at an old-stock:new-stock ratio of 10:3. As a result, the reported stock price increased by 333 percent. We account for these 
consolidations by dividing all stock prices by the consolidation ratio (3.333 in our example) after each consolidation.

The exact dates of stock consolidations are indicated in the monthly publications of Börse und Wirtschaft, later Monatskursblatt Berliner Börse. To obtain consolidation ratios we exploit information on adjustments to the highest and lowest stock prices that are reported in Börse und Wirtschaft, later Monatskursblatt Berliner Börse. ${ }^{48}$ After a consolidation, the highest and lowest stock prices are adjusted to reflect the consolidation. This allows us to calculate exact consolidation ratios. For example, the highest and lowest stock price for Dresdner Bank were reported as $18 \frac{1}{2}$ and 24 in July 1932 but the reporting changed to $61 \frac{2}{3}$ and 80 in August 1932 (Dresdner Bank stocks were consolidated on August 4, 1932).

In exceptional cases, the highest and lowest stock price changes in the same month as the consolidation. In those cases, we use the change in the stock price on the date of the consolidation to infer the consolidation ratio. For example, Brown Boveri stocks were consolidated on January 4, 1935. As the consolidation happened early in the year, highest and lowest stock prices were reported only after the consolidation and we can therefore not observe adjustments in the reporting of highest and lowest stock prices. We therefore use the ratio of stock prices on the last trading day before the consolidation (January 3, 1935, stock price:14 $\frac{3}{4}$ ) and the stock price on the day of the consolidation (January 4, 1935, stock price: 74$)$. The consolidation ratio is therefore $5.02(74 / 14.75)$ in this example.

Deduction of Subscription Rights: Between 1929 and 1943 some firms issued new stocks and offered existing shareholders a subscription right to prevent stock dilution. Starting from the day this subscription right is executed, the monthly publications of Börse und Wirtschaft, later Monatskursblatt Berliner Börse report stock prices excluding the subscription right. For example, Deutscher Eisenhandel $A G$ issued new stocks in 1936 and offered existing shareholders a subscription right. The subscription right is valued 6.5 percent and deducted starting from August 10, 1936. As a consequence, the stock price drops mechanically from 138.50 on August 8, 1936 to 132 on August 10, 1936. We adjust for these deductions by multiplying all subsequent stock prices by an adjustment factor, defined as the ratio of the old price with subscription right divided by the old price minus the subscription right. ${ }^{49}$ In the case of Deutscher Eisenhandel AG this adjustment factor is given by $1.049\left(\frac{138.50}{138.50-6.50}\right)$.

\section{B.2.2 Dividend Data}

The historical listings (called Börse und Wirtschaft, later Monatskursblatt Berliner Börse) of the Berlin Stock Exchange report dividend payments for the sample firms (see Figure B.4 for an example). As stocks that get delisted early in the year do not report the latest dividend payment, we augment

\footnotetext{
${ }^{48}$ Highest and lowest stock prices are reported for the calendar year.

${ }^{49}$ This adjustment is standard practice in the construction of long-run stock indices. It assumes that the value of the subscription right is re-invested into the same stock to prevent stock dilution (Ronge 2002, p. 58).
} 
the data from the Berlin exchange with information on dividend payments from the Handbuch der deutschen Aktiengesellschaften (1935 and 1941).

Dividends are generally reported in percent of nominal capital. Insurance firms, however, report dividends in Reichsmark (RM) per stock. To obtain a consistent database we convert the latter into percent of nominal capital.

\section{B.2.3 Stock Price Adjustments for Dividend Payments}

For Appendix Figure A.2, we compute stock prices by taking into account that investors receive annual dividend payments in addition to capital gains. We collect dividends and their payment dates from Monatskursblatt Berliner Börse and augment dividend payments with data from Handbuch der deutschen Aktiengesellschaften 1925 and 1941. To compute stock prices that reflect total returns, we adjust stock prices for price changes that are entirely due to dividend payments (following standard practice as outlined in Ronge 2002). After a dividend payment, we multiply the stock price by an adjustment factor, which is defined as the ratio of the pre-payment price divided by the pre-payment price minus the dividend. We use the last observed price in our dataset prior to the dividend payment as the pre-payment price. In some cases, the exact dividend payment date is missing in the Monatskursblatt Berliner Börse. As the average firm in our sample pays the dividend between May and June (but closer to June 1), we use June 1 as the pre-payment price for dividend payments with missing dates.

\section{B.2.4 Return on Assets}

We digitize data on profits and assets from the 1932 and 1941 editions of the Handbuch der deutschen Aktiengesellschaften. The 1932 edition of the Handbuch der deutschen Aktiengesellschaften reports the income statements and balance sheets for the year 1931, while the 1941 edition reports the years 1936 and 1940. The return on assets is the ratio of profits before interest payments and taxes (calculated from the income statement) to total assets (from the balance sheet). To calculate profits before interest payments and taxes, we use the book value of profits and subtract the profit carryforward from the previous year, subtract the net income from the sale of own stocks, subtract the net income from payments out of reserve funds, add depreciation, add taxes, and add interest payments.

Many of the 655 firms in our estimation sample do not report the income statement and balance sheet items that are required for the calculation of the return on assets. As a result, the data allow us to calculate the return on assets for 289 firms in at least one year (1931, 1936, or 1940). Two firms do not report values in 1936 or 1940, so we use the 1937 and 1939 values, respectively. Dropping these observations from the sample does not affect the results. 


\section{B.2.5 Firm Age, Nominal Capital, Reporting Period, Industry}

We collect data on firm age, nominal capital, and the industry of the firm from Handbuch der deutschen Aktiengesellschaften (1932). We collect data on the period during which the balance sheet is reported from Monatskursblatt Berliner Börse.

\section{B.2.6 Information on Jewish Firms}

We consult historic sources that identify Jewish firms (Bruer 1927; Landsberg 1927a,b; Priester 1927; Mosse 1987). We extract all firms that are listed as Jewish in at least one of the sources. Figure B.5 provides an example from Landsberg (1927b). The author describes the historical development of the textile industry and lists Jewish firms in various sub-industries, for example, the furniture and carpet industry. In the excerpt, Landsberg lists among other firms G. Feibisch and Nordeutsche Trikotweberei $A G$, which are listed on the Berlin Stock Exchange.

Figure B.5: Example from Landsberg (1927b)

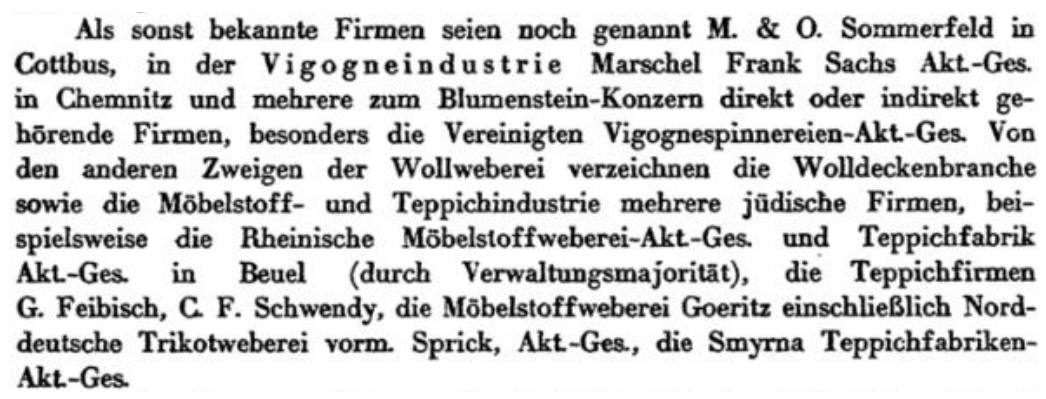

Notes: The figure displays an excerpt from page 108 of Landsberg (1927b).

\section{B.2.7 Identifying Jewish Shareholders}

We collect information on all large shareholders of the 655 firms listed on the Berlin Stock Exchange from the 1932 edition of the Handbuch der deutschen Aktiengesellschaften. We match the list of these large shareholders with our lists of Jewish managers and Jewish firms. For shareholders that are not listed in these sources we conduct an internet search to find further information on the respective individual or firm. The following example provides an overview of the procedure.

\section{Example Internet Search}

One example of a firm listed on the Berlin Stock Exchange is Baroper Walzwerk AG. The firm reports Wolf Netter \& Jacobi-Werke KGaA as one of its large shareholders. We first check whether Wolf Netter \& Facobi-Werke KGaA appears in sources about Jewish firms (see Section B.2.6). After not finding it in these sources, we conduct an internet search for Wolf Netter \& Facobi-Werke KGaA. We find Wolf Netter \& Jacobi-Werke KGaA in the database fewish Businesses in Berlin 1930-1945 (available at: https://www2.hu-berlin.de/djgb/www/find?language=en_US), which is based on the 
research of Kreutzmüller (2017). This allows us to classify Wolf Netter \& Facobi-Werke KGaA as a large Jewish shareholder of Baroper Walzwerk $A G$.

\section{B.3 Further Details on Industry Classifications}

In the main specification, we control for 10 industry categories each interacted with 30 time dummies, i.e., 300 additional regression coefficients. The industry categorization is based on the industry classifications developed by Ziegler (2000b). This is our preferred categorization because finer industry categorizations result in industry groups with relatively few firms. We also show robustness checks with finer industry classifications (see Appendix Table A.6). The data for the finer classifications come from Handbuch der Deutschen Aktiengesellschaften 1932. The Handbuch orders firms by 22 industry categories. Some of these categories include quite a large number of the 655 firms. For example, the category "metal industry, machine tools, vehicles, ships, and auto industry" includes a relatively diverse set of firms.

The entry of each of the 655 firms describes the firm's activities. We carefully read each of those entries to identify the main activity of each firm to split them into finer industries, for instance, a separate category for metal industry, for machine tools, and so on. This results in an industry classification with 43 categories. The finer industry classification is used to classify industries into STEM and non-STEM industries for the results presented in Table 6 and to estimate industry-level spillovers shown in Appendix Table A.17.

\section{B.4 Further Details on Cartels}

We hand-collect data on membership in cartels for all 655 firms in our data. The data come from Handbuch der Deutschen Aktiengesellschaften in 1932. We carefully read the entry on cartel memberships of each of the 655 firms in our sample and record their memberships.

While about 75 percent of firms in our sample do not belong to a cartel, about 25 percent are members of one or more cartels. For example, the chemical firm Schering Kahlbaum A.G. was member of the Deutsches Bromsalz-Syndikat (German Bromide Syndicate) and the Deutsche Boraxvereinigung G.m.b.H (German Borax Union).

\section{B.5 Further Details on Measures of Lower-Level Jewish Employees}

We collect measures of lower-level Jewish employees from publications of the German statistical agency (Statistik des Deutschen Reichs) that are based on the German census of 1933. The publications report the number of Jews by occupational level (for example, workers, blue collar workers, and white collar workers), sector (manufacturing or services), and region (for example, East Prussia without Königsberg) or large city (for example, Berlin, Hamburg, Breslau, or Königsberg). Whenever we are able to use the city-level information, we do so (for about 33 percent of the sample). Otherwise, we use the regional information. We also obtain similar information for all German 
workers and then calculate the share of Jews among blue collar workers (category "l" in the census data) and lower-level white collar workers (category "a” in the census data).

\section{Online Appendix: Further Robustness Checks Stock Price Results}

We conduct a number of additional robustness checks for the stock price results. We find that various ways to control for firm size do not affect the findings, including parametric and nonparametric controls for nominal capital, for the total number of managers, and for both variables simultaneously (Appendix Table A.21, columns 1-3). There is no heterogeneity in the effects by firm size (columns 4-6).

Some firms were not traded in the plus-minus 10-day window around each January 10th and July 10th, either because the stocks were relatively illiquid, or because firms were no longer listed on the Berlin Stock Exchange. The results are robust to restricting the sample to regularly traded firms and become even larger, in absolute magnitude, if we restrict the sample to firms without any missing observations (Appendix Table A.22). The results are also robust to limiting the sample to firms that were never delisted (columns 7-8).

We investigate whether firms that lost Jewish managers were more likely to be delisted from the stock market. We regress an indicator for whether the firm was delisted after January 1933 on the fraction of Jewish managers in 1932. The coefficient is negative, small, and insignificant, indicating that firms with Jewish managers were not more likely to be delisted (Appendix Table A.23, column 1). The results are similar if we add the full set of control variables (column 2), or if we estimate an extended Cox hazard model (columns 3-4).

\section{Online Appendix: What Type of Connections Matter? - Katz and Eigenvector Centrality}

We analyze network measures, which capture higher order links between firms. We start with different forms of Katz centrality, which are based on the seminal work of Katz (1953). Katz centrality measures the centrality of a firm recursively: a firm is more central if it is connected to other central firms, which themselves are connected to other central firms, and so on. In our context, Katz centrality measures influence in a network by taking into account not just direct managerial links between firms, but also indirect links that arise because other firms are connected to each other. Katz centrality computes the number of direct neighbors in the network (first degree connections) and also connections to all other firms in the network (higher order connections). The Katz centrality of firm $i$ is defined as: 


$$
\operatorname{Katz}_{i}(\alpha, \beta)=\alpha \sum_{j} A_{i j} K a t z_{j}+\beta .
$$

The parameter $\beta$ controls the initial centrality. ${ }^{50}$ The parameter $\alpha$ (known as attenuation factor) determines how much higher order connections are penalized. Each connection between a pair of firms is assigned a weight $\alpha^{k}$, which is determined by $\alpha$ and the distance $k$ between nodes. For example, a first degree connection (a direct managerial link between firms) receives a weight of $\alpha$, a second degree connection receives a weight of $\alpha^{2}$, and so on. $A_{i j}$ refers to an element of the adjacency matrix $A$ of the firm-level network. $A$ lists which firms are linked through their managers. ${ }^{51}$

With $\alpha$ approaching 0 , Katz centrality converges to degree centrality, and in the limit only first degree connections are considered. As $\alpha$ increases, higher order connections receive increasing weights. The highest possible $\alpha$ is the inverse of the highest positive eigenvalue of the adjacency matrix $A$. In that case, Katz centrality converges to a measure known as eigenvector centrality (Bonacich 1987). ${ }^{52}$ (For $\alpha$ greater than the largest eigenvalue, the algorithm to compute Katz centrality does not converge.)

We measure the importance of Jewish managers for their firms' Katz centrality as:

$$
\text { Importance of Jews for Katz Centrality }(1932)_{i}=\frac{K a t z_{i}^{A l l}-K a t z_{i}^{\text {Non-Jews }}}{K a t z_{i}^{A l l}} \text {, }
$$

where $\mathrm{Katz}_{i}^{\text {All }}$ refers to firm i's Katz centrality based on Jewish and non-Jewish managers in 1932 and $K a t z_{i}^{\text {Non-Jews }}$ refers to firm $i$ 's Katz centrality based only on non-Jewish managers in $1932 .{ }^{53}$

We investigate how changes in different network centrality measures, which were caused by the removal of Jewish managers, affected firm performance. Specifically, we show results for different values of $\alpha$, from close to 0 to the highest possible $\alpha$ (eigenvector centrality). The results indicate that changes to Katz centralities with a low value of $\alpha$ have large effects on stock prices

\footnotetext{
${ }^{50}$ Firms with no direct connections therefore have a Katz centrality of $\beta$. Because we construct a ratio of Katz centralities (see below), the results are invariant to using different levels of $\beta$.

${ }^{51}$ The summation of each row of matrix $A$ corresponds to the degree centrality (see above) of the firm represented in that row.

${ }^{52}$ Eigenvector centrality is at the heart of Google's PageRank algorithm (Brin and Page 1998).

${ }^{53}$ In contrast to degree centrality, where $\frac{\text { Degree Centrality Jews }}{\text { Degree Centrality }}=\frac{\text { Degree Centrality } \text { All }_{- \text {Degree Centrality }}{ }^{\text {Non-Jews }} \text {, fogree Centrality }}{\text { All }}$, for Katz cen-

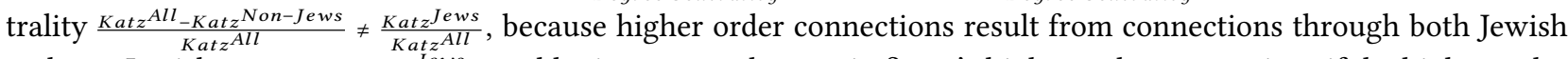
and non-Jewish managers. $\frac{\text { Katz } \text { Kaws }_{\text {ew }} \text { wall }}{\text { Katz }}$ wismeasure changes in firm $i$ 's higher order connections if the higher order connections were not linked through a direct chain of Jewish managers. In the example shown in Appendix Figure A.5, we have added a manager 5 who was Jewish. Firm A's network due to only Jewish managers includes first degree links to firms B and C (but not the link to firm E, because the link to firm D comes from a non-Jewish manager). The complete network includes first degree links to firms B, C, D and one second-order link to firm E. With the dismissal of Jewish managers, firm A loses one first degree link to firm B, half a first degree link to firm C, and one second degree

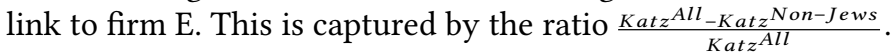


(Appendix Table A.13, columns 2-3). For low $\alpha$, second and higher order connections receive almost no weight and the measure is very close to degree centrality. For example, for $\alpha=0.0005$, first order connections receive a weight of 0.0005 and second order connections receive a weight of $0.0005^{2}=0.00000025$ and so on.

As we increase $\alpha$, changes to Katz centrality measures have less of an effect on firm performance (Appendix Table A.13, columns 4-5). In our data, the highest positive eigenvalue is 84.65 and its inverse, and thus the highest possible $\alpha$, is $0.0118 .^{54}$ There is no evidence that changes in eigenvector centrality, which gives maximum weight to higher order connections, affect stock prices (column 6). Taken together, the results suggest that changes in first order connections had large effects on stock prices, but that changes in higher order connections were less important. ${ }^{55}$

\footnotetext{
${ }^{54} \mathrm{We}$ approximate the eigenvector centrality with a Katz centrality using the highest possible $\alpha$. The ratio $\frac{\text { Katz }^{A l l} \text { Katz }_{\text {Kan-Jews }} \text { ill }}{\text { Katz }}$ is only meaningful if it is based on Katz centralities that are calculated with the same value of $\alpha$. The network based on all manager connections has a higher eigenvalue than the network based on only non-Jewish managers. Hence, eigenvector centrality scores in the two networks would be calculated on the basis of different largest eigenvalues, and the eigenvector centrality scores would no longer be comparable.

${ }^{55}$ Note that considering higher order connections moves more and more firms into the treatment group. Even firms that did not lose Jewish managers become treated because they lose higher order connections. When we chose a relatively high $\alpha$, no firm that had employed Jewish managers lost less than 20 percent of its direct and higher order connections, and we can therefore not separately estimate the coefficient with less than 20 percent of all characteristics.
} 